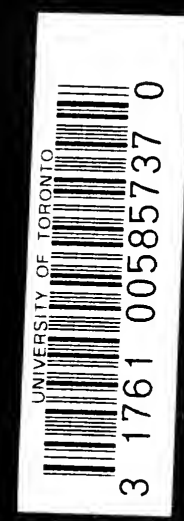

Itswor

igstome

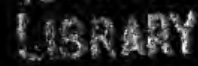



,

$$
\text { , }
$$






\section{BYRON AND BYRONISM IN AMERICA}

BY

WILLIAM ELLERY LEONARD, A.M.

Submitted in Partial Fulfilment of the Requirements for the Degree of Doctor of Philosophy, in the Faculty of Philosophy, Columbia University

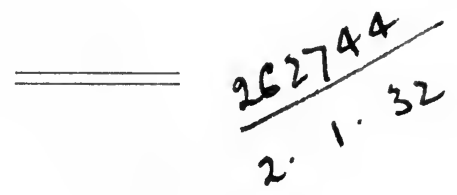

B O S T O N

I $9 \circ 5$ 


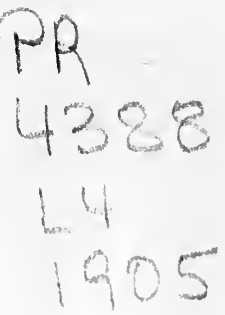

THE Nichols PREgS:

THOS. P. NICHOLS, LYNN, MASS. 


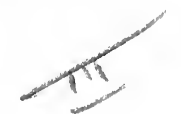

Decipit exemplar vitiis imitabile...

O imitatores, servum pecus, ut mihi saepe

bilem, saepe iocum vestri movere tumultus.

HORACE, Epistles $i$, xix. 
4.4 


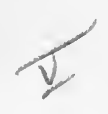

\section{PREFACE.}

THIS investigation was undertaken at the suggestion of requirements for the doctorate at Columbia University. Most studies of American literary history have dealt with a few distinguished men; the milieu in which they lived, though frequently touched on in criticism or biography, is but just beginning to occupy the special student. These pages form a very modest, but, I trust not useless, contribution to our knowledge of that milieu.

America, true to its principle of democratic freedom, has expressed itself very fully: every man or woman, who has had, or has thought he has had, something to say, has said it - and printed it. This has not been an unmixed blessing; the result has often served to make us ridiculous. But it may also serve as a valuable record of the American mind, which in its weakness, no less than in its strength, has its interest, even where it has not always its attainment. An accumulation of such research work as Prof. Cairns' account of early magazine literature, Prof. Smyth's Philadelphia Magazines, and Mr. F. H. Wilkins' Early Influence of German Literature, could not but be of much service to that future historian of American Literature, whose task may be rather to trace conditions and tendencies - provincialism and imitation, the beginnings of nationalism, the finding of speech, the effect of social and political environment, of immigration and race-fusion, etc. - than the achievements of individuals. 
This essay might, perhaps, have been planned on a more speculative, and, for that reason to some readers, a more interesting basis; but the materials were found very recalcitrant and confusing, and it was felt that any arrangement, other than a chronicle of facts under simple heads, would have but a specious clearness. Moreover, as it could not be premised that the reader would be familiar with the greater portion of the materials to be discussed, there might otherwise have seemed an unintentional factitiousness in the reflections.

I must especially thank Prof. K. D. Bülbring of Bonn, Germany, whose lectures and seminar aroused a long dormant interest in Byron, and Prof. W. P. Trent of Columbia University, whose understanding of America stimulated, after a prolonged sojourn in Europe, my interest in our own literary life. I am indebted to the Library of the University at Bonn for opportunity to gather, during the summer before last, materials for the introductory chapter; for the rest to the courtesies of the Lenox and Astor Libraries of New York, the Public Library and the Athenæum of Boston, the Library of Harvard University, and that of Brown University, where Prof. W. C. Bronson obtained for me the privileges of the Harris Collection of American Verse. To the unfailing courtesies of Mr. Erb of the Columbia Library, in common with many students of the University, I owe also not a little. I am indebted to my father for editorial suggestions and to The Nichols Press for courtesies in the printing. But circumstances, attending both the preparation and the proofreading, may have somewhat hindered me in turning all this kind assistance to best account, and I am alone responsible for any errors and other shortcomings that the reader may detect.

William Ellery Leonard.

Philadelphia, Jan. $19,1905$. 


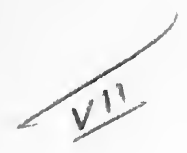

\section{CONTENTS.}

PREFACE ...................... v

Chapter I. - Introduction - Byron on the Continent - Literary America before Byron . . . . . . I

Chapter II. - The Beginnings. - Byron in Early NewsPapers and Magazines . . . . . . . . . . 19

Chapter III. - Byron's Literary Influence, I815-1830 36

Chapter IV. - Byron's Literary Influence, I830-1860 55

Chapter V. - Byron's Sub-Literary Influence . . . . 67

Chapter Vi. - Byron in American Criticism - Some Explanation of Byron's American Vogue - ConClusion . . . . . . . . . . . . I00

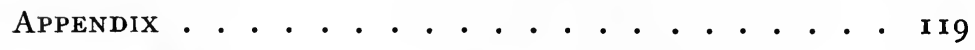

BIBLIOGRAPHY ............... . 123 
<smiles>C1=CCC1</smiles> 


\section{CHAPTER I.}

INTRODUCTION. - Byron on the Continent. - Literary AMERICA BEFORE BYRoN.

G EORGE BRANDES, the Dane, calls Byron the starting point for the study of nineteenth century literature. He is speaking of the Continent. Despite the tribute to Byron's fame in the two new English editions of Henley and of Prothero and Coleridge and some suggestion of a "Byron revival," despite the historical or speculative interest of special students, he occupies, it is evident, no such high position in England or America today. "Byron is exploded for good," remarked an English critic two or three years since to Prof. Bülbring, of the University of Bonn, who was then in England on a tour of orientation, and an American essayist writes under the rubric "Is Byron Dead ?" Nor, indeed, has Byron ever occupied precisely that position in England and America. For all the admiration of Scott, of Moore, of Shelley, of Arnold, among English and American poets who is there that reveals in his poetry the mastership of Byron? "There is," says Roden Noel, " little response in our literature, as there is in that of the Continent, to what is strongest and highest in Byron." ${ }^{2}$ In England

1 See The Wholesome Revival of Byron by P. E. More, Atlantic Monthly, 1898 ; The Byron Revival by W. P. Trent in The Authority of Criticism and other Essays, Scribner, 1899.

${ }^{2}$ Lord Byron and his Times in Essays on Poetry and Poets, London, 1886. He says further: "In England the Byronic growths have taken their nourishment from the more morbid elements in him." 
he is to be found a definite force among the minor poets, as Felicia Hemans, ${ }^{1}$ Leigh Hunt, ${ }^{2}$ Sidney Dobell, ${ }^{8}$ Barry Cornwall, ${ }^{4}$ whom Byron called

"my gentle Euphues

Who, they say, sets up for being a sort of moral me," 5

Elizabeth Norton, ${ }^{6}$ Roden Noel, ${ }^{7}$ and the present Laureate, whose reply to Mrs. Stowe's famous attack is, however, his best claim to be named with Byron. Of England's great there is Byron in the first volume of Mrs. Browning ${ }^{8}$ something of his mood in Swinburne, and it has been said ${ }^{9}$ - I will not say it - in Tennyson's " divine despair." What influence he exercised on American literature, in the stricter sense of the word, will appear later. Wordsworth and Keats, not Byron, are the starting points for what is best, poetically best at least, in English and American literature in the nineteenth century.

English Byronism, except for occasional comparison, it is not my purpose to pursue further. But in America, it is certain that Byron was, up to the Civil War, a most popular model and that Byronism was no inconsiderable phase in the history of our taste and culture, which deserves, trivial and amusing as it may often seem, to be recorded with some seriousness $/$ First, however, for the sake of clearness and perspective, it may be well to review Byron's influence on the Continent and literary America before Byron.

${ }^{1}$ See Modern Greece, Restoration of Arts to Italy; the two tales, The Widow of Crecentius, The Abencerrage.

${ }^{2}$ See Legend of Plorence.

${ }^{3}$ See The Roman.

${ }^{4}$ See Marcian Colonna.

5 Don Juan, xi, 59.

'See The Dream, The Child of the Isles.

"See "Byron's Grave" in appendix to his Life of Byron, 1890.

8 Matthew Arnold's early poem "Alaric at Rome," recited in Rugby School, June 12, 1840, imitated Childe Harold, and Bulwer's early poems are Byronic.

9 Namely, in the Edinburgh Review, Oct., 1900. 
I.

Byron's vogue abroad was immense long before his death. His poems were translated almost as they appeared. Contemporary newspapers there, as in England and America, bear witness that his portrait was as familiar as Napoleon's ${ }^{1}$ and to be seen in all the shop windows. Melancholy poseurs were wearing Byron collars and cultivating passion and remorse. ${ }^{2}$ But he meant more to great souls. Goethe, who followed his career closely, ${ }^{3}$ translated passages from Don Juan and Manfred and sent the poet poetical best wishes as he embarked for Greece. The early dead Euphorion, symbolic birth of the classical and romantic spirit, in the second part of Faust ${ }^{4}$ is none other than Byron, as Goethe has elsewhere testified. Of French celebrities, Madame de Staël knew him personally. In Italy he became among poets and politicians, naturally, almost one of them, and the poetic ideal of many a younger Italian, who, like Guerazzi, declared Byron " the dear guide of his thoughts." 5

Nor did Byron's voice cease to be heard on the Continent when it was hushed amid the marshes of Missolonghi, but it echoed on to the Caucasus, to the Pyrenees and beyond; and the people, impoverished by the Napoleonic wars, politically crushed by the Holy Alliance, and socially emasculated by law and custom, heard in that echo

${ }^{1}$ See Essais by Otto Gildemeister, Berlin, 1897.

${ }^{2}$ In Paris, for example, "Il était de mode alors dans l'école romantique d'être pâle, livide, verdâtre, un peu cadavéreux, s'il était possible. Celà donnait l'air fatal, byronien, giaour, dévoré par les passions et les remords."-Th. Gautier, Histoire du Romantisme, chap. iii.

${ }^{3}$ See Lebensverhältnis zu Byron, Werke, 1833, xlvi, 221-5; Tages und Jahresheften, 1817; Gespräche mit Eckermann, passim; Brandl, Goethe's Verhältnis zu Byron, Goethe Jahrbuch, vol. xx,1899; George Ticknor's Life, Letters and Journals, for Oct. $25,1816$.

* Act iii ; read especially the Trauergesang.

"Scorta amorosa de suoi pensieri." 
its universal speech. Wordsworth was at once insular and reflective in his poetry of optimism and of freedom; Shelley had lived and sung in a world of abstractions and dreams; Goethe from the Olympus of art was considering all phenomena of human life with that serenity, which, to such chafed spirits as Börne, ${ }^{1}$ seemed almost criminal indifference; and Schiller, than whom no nobler idealist and patriot ever breathed, was too philosophic, emphasized too soberly law in freedom, and believed too profoundly that the test of maturity in nations, as in men, was the recognition of this law ${ }^{2}$ to meet these turbulent times that tried men's souls. He died, moreover, early in the period. Byron alone had felt and grasped the facts and conditions, the complex mood of world-sorrow, cynicism, revolt, freedom, hope. Byron, above all men, had contributed "to reëstablish in the heart of crushed and servile Europe sentiments of dignity and human liberty." 3

When the better days came, his influence still endured by virtue of his "sincerity and strength," his profound appeal to the emotions as in Childe Harold and the lyrics, and his intellectual, though not spiritual, insight in Don Juan, into those social vices, which transcend any particular time or place. His poetry, without the subtle verbal felicity which makes Keats' Hyperion or Goethe's Iphigenie forever untranslateable and only a half delight to any but a master of the English or German, probably loses less than that of any poet, equally great, when well done into

1 See his Tagebücher. It was he who said: "Ich gäbe alle Freuden meines Lebens für ein Jahr von Byron's Schmerzen hin."

"Was ist denn reif sein, wenn nicht ein Gesetz

Für sich und für die Sterne anerkennen?" -Wallenstein.

" "A ridestare nel cuore dell" Europa serva ed avvilita sentimentidi dignitd e libertd umana."-Guiseppi Chiarini, Lord Byron nella politica e nella letteratura della prima meta del secolo. Nuova Antologia, 1891. 
another tongue ${ }^{1}$ and its defects of harshness, bad grammar, awkward and bizarre constructions, so obvious to us, the foreigner the more readily pardons, feeling them less. Its defects in architectonics are to him of less importance, for, if a long-growing impression does not mislead me, the Continental reader lays relatively more stress on the spirit as such, than has artistic England of the past seventy-five years. Its blasphemy and obscenity, in so far as they are real, have never been such a stumbling block on the Continent ${ }^{2}$ as in England and America.

The list of Continental poets who came under Byron's spell is long and distinguished. In Denmark there was Frederich Paludan-Müller ; ${ }^{3}$ in Norway, Heinrich Wergeland. In Germany, Wilhelm Müller and Chamisso wrote hymns on Byron's death. ${ }^{4}$ His personality attracted both novelists ${ }^{5}$ and dramatists. ${ }^{6}$ His tales and episodes in his poems have been frequently worked out into novels and

1 Let the reader, who has the German Sprachgefiuhl, peruse Childe Harold in the splendid Spenserians of Gildemeister. Betteloni's translation of Don Juan has appealed to Italians, at least, as "in alcuni parti assolutamente meraviliosa." For those who read Dutch it may be interesting to look at Beet's. In Russia Schukoffski's Chillon is said to be a classic.

2 Yet the myth of Byron's evil origin, that caused good English dames to faint when he entered the room, once received some credence even in Spain. Don Marcelino Menéndez y Pelayo in a preface to Poemas dramaticos de Lord Byron (Madrid, 1886), translated by Don José Alcalá Galiano, bears indirect witness when he says: "Byron no es ya para nosostros aquel poeta satánico ó endiablado que llenaba de terror á nuestros padres."

${ }^{3} \mathrm{Cf}$. "Til os $i$ Danmark forplanter hans Aand sig gjennem Frederik PaludanMiillers fortaellende og bibelskdramatiske Digde. Byrons himmelstormende Aand faar her Daaben, hansstore politiske Trods bliver til en Eneboers hvasse Satire, hans flaengende Haan omformes til Udtryk for en kristelig og borgerlig Morals Dommedag over Spidsborgerlighedens Forfaengelighed og Nydelsessyge."-Brandes, Byron, in Fremmede Personligheder, Copenhagen, 1889.

4 See, respectively, Totenklage in the Griechen Lieder, 1824 ; and Lord Byron's Letzte Liebe, 1827 ; also Zedlitz's Toten Kränze, 1827.

${ }^{5}$ See Ernst Wilkomm, Lord Byron, ein Dichterleben, 1839, 8 vols. In England we have Lady Caroline Lamb's Glenarvon, 1816, a personal attack, and Disraeli's Venetia, 1837.

'See Carl Bleibtreu, Lord Byron's Letzte Liebe, Byron's Geheimnis, the latter in 1900 ; and Rudolph Gottschall, Lord Byron in Italien, 1847. 
poems, ${ }^{1}$ while, since 1875 , there have been no less than five dramas on Marino Faliero, ${ }^{2}$ all related to Byron as source. His gloom is reflected in the lyrics of Grillparzer, of Geibel, who also has Greek poems reminiscent of Byron, of Lenau, and of Heine, who is " the German Byron." ${ }^{3}$ In his youth Heine fancied, like many a lessgifted aspirant, that his mind was cast in a similar mould, and his early drama Ratcliff betrays its model by its motto and its wild, dark character. Platen's Venezianische Sonetten, in mood and imagery, recall Childe Harold, as do Zedliz's Toten Kränze and Heine's Reisebilder. Grün's Schutt, especially part one, has similarities with The Prisoner of Chillon. It was in Young Germany (im jungen Deutschland) that the shallower imitation of his personality and his tales reached its height. But as a champion of freedom ${ }^{4}$ he remained a living fire, which flamed out anew during the revolutionary upheaval of 1848 , in Freiligrath and others. For the past thirty years he has been more a literary force, chiefly through his dramas ${ }^{5}$ and Don Juan; through the latter he has been, also, a social force. As early as 1850 , Böttger ${ }^{6}$

1 The Prisoner of Chillon and Mazeppa were made into prose romances and Parasina into a drama. Gautier, in France, also dramatized Parasina.

${ }^{2}$ Namely, by Lindner, Kruse, Greif, Effendi and Walloch. There is one also by Delavigne, in French.

${ }^{3}$ See Felix Melchior, Heinrich Heines Verhältnis zu Lord Byron, Berlin, 1903.

${ }^{4}$ See Brandes, Der Naturalismus in England (Ger. trans. p. 96) for a discussion of Byron and freedom.

${ }^{5}$ But concerning his dramas on the German stage: "Dauerndes Besitztum der deutschen Bühne ist ausser Byron's Manfred-dieser aber auch nur durch die Musik-keines der wertvolleren englischen Dramen nach Shakespeare geblieben. Versuche der Aufführung sind in langen Zwischenräumen mit allen grösseren Stücken Byron's wiederholt gemacht worden; mit daurendem Erfolg niemals. Man hat seine Foscari und den Marino Faliero gespielt, hat sich selbst an den Cain gewagt, mit und ohne Musik, und vor bald zwei Jahren wurde eine Auffïhrung des Sardanapalus in Berlin versucht . . . . In früheren Zeiten, war Sardanapalus eines der Lieblingsstücke der Berliner Oper, nämlich als -Ballet!" - Eduard Engel in the Hamburger Fremden-Blatt, for Sept. 19, 1903.

- The first German to translate Byron entire ; he wrote also two Byronic tales. 
imitated Don Juan in his Eulenspiegel; Oelschläger's Novellen in Octaven (1882) in rhymes and humor, and Grosse's Volkramslied (I89o) in attitude toward society both acknowledge Don Juan. This masterpiece now so neglected at home and with us, is studied in Germany " to learn from it how to represent realistic Weltschmerz and the life of the present age." ${ }^{1}$ The poet, who long figured as a leader in romanticism, has become the teacher of realists. ${ }^{2}$

In France, ${ }^{3}$ Lamartine, who wrote in 1825 Le Dernier chant du pèlerinage de Childe Harold in Alexandrine couplets, ${ }^{4}$ had most of Byron's Weltschmerz $;{ }^{5}$ Hugo in his oriental poems and in those odes of pain, doubt and irony, is often Byronic, but he was inspired most by Byron's passion for liberty, as was Delavigne in his Messeniennes ; ${ }^{6}$ De Vigny was attracted chiefly by his orientalism, especially that of the Biblical dramas. Musset, of all poets, perhaps Byron's most legitimate successor, ${ }^{7}$ and one of his most rapt worshippers, ${ }^{8}$ displays most of the cynicism

${ }^{1}$ Prof. Ackermann, Lord Byron, Heidelberg, 1901. What Ackermann means by " realistischer Weltschmerz" can be illustrated by a comment on Bleibtreu. His is "Weltschmerz, aber nicht in romantischerVerklärung, wie in der ersten Hälfte des Jahrhunderts, sondern mit der realistischen Bitterkeit und Nïchternheit der Gegenwart."

2 "It is in Don Juan that Byron stands forth as the founder and precursor of modern realism in poetry." - Edinburgh Review, Oct., 1900.

3 "Un poète étranger, jusqu'alors inconnu de la plus grande partie des lecteurs français a conquis en peu de temps une réputation colossale parmi nous . . . . bientôt l'admiration a pris le caractère d'un engouement véritable. On $n$ 'a plus parlé que des chefs d'oeuvre de lord Byron." - Revue Encyclopédique, Jan., 1820, article by Thiesse.

${ }^{4}$ Translated in the 40's by W. W. Smith, of Charleston, S.C., into Spenserians.

"A contemporary skit runs :

"Je n'aime pas Fénelon

Ni ce pauvre Racine

Mais jaime bien lord Byron

Et Monsieur Lamartine."

- From the Paris journal, Le Diable Boiteux, Oct. 8, 1823.

${ }^{B}$ Among Fauriel's Chants populaires de la Grèce moderne some are translations from Byron.

7 "C'est Alfred de Musset qui rapelle le plus souvent lord Byron par la forme comme par le choix de ses sujets." - Alex. Buchner, Etude sur lord Byron, Cherbourg, 1874.

${ }^{8}$ See Confessions d'un enfant du siecle. 
of Don Juan. He has, however, as in Mardoche and Namouna, a more delicate fancy and a lighter touch.

In Italy, besides Silvio Pellico, Ugo Foscolo, Manzoni, the head of herromantic movement, and that noble pessimist, Leopardi, ${ }^{1}$ there was Giovanni Berchet, who, like Byron, hated Austria, and figures as "the Italian Byron." The political situation forced Berchet into exile and he made his home in Greece thereafter, and these two circumstances, somewhat paralleled in Byron's own career, were not without import for the Byronic elements in his poetry. A writer ${ }^{2}$ in the $N u o v a$ Antologia declares, "In general, one can say that in all our political and romantic literature from 1820 . . . . the influence of Byron is more or less to be felt." Only the specialist would have the data to control so bold a statement, still its very possibility is significant; in England or America it would be sheer nonsense.

In Spain, Mariano José de Lara (1809-37), Angel Saavedra de Rivas and José de Espronceda (1810-42) may be named. Espronceda, handsome, dissipated, an adventurer and liberal in politics, whose fiery poetry is drawn from his own troubled times and troubled life, became inevitably "the Spanish Byron." His famous Estudiante de Salamanca and El Diablo mundo are modelled on Don Juan. ${ }^{3}$ In a Spaniard, it will be remembered, in Castelar, Byron won his most enthusiastic biographer.

Russian poetry, as Russian society, is peculiarly in-

${ }^{1}$ See Giulio Monti, Giacomo Leopardi e Giorgio Byron, Studi Critici, Firenze, 1887; also Francesco de Sanctis, Studio sul Leopardi, Napoli.

${ }^{2}$ Chiarini, see supra.

${ }^{3}$ Gaspar Nuñez de Arce, who voiced the Spanish point of view in calling Byron " $e l$ mas grande de los poetas ingleses del siglo presente," wrote his Ultima lamentacion de Lord Byron in ottava rima. The 17 th edition was printed at Madrid in 1881 . Ottava rima verse had long been employed in Spain; but Don Juan may have increased its popularity. 
debted to Byron, and her two greatest poets were his not unworthy disciples. Pushkin, ${ }^{1}$ at one time exiled to the Caucasus, wrote tales whose heroes and women, as in the Prisoner of the Caucasus (I82I), were like Byron's. His masterpiece was, however, Eugen Onägen (I823183I). This draws on both Don Juan and Childe Harold, but throughout Pushkin remains Russian. Its descriptions and its people are depicted from his environment. The Russian critic, Bielinski, has called it an encyclopedia of Russian life. ${ }^{2}$ Lermontoff, in the opinion of a Russian friend ${ }^{3}$ of the writer, betrays even more of Byron's influence than does Pushkin. His Hero of the Caucasus, in its women and grand mountain pictures, reminds one of the tales and the third canto of Childe Harold. Both were inspired to freedom by Byron, and Pushkin is recognized as the forerunner of Nihilism. It is well known that the Poles in their tragic national sorrow found in Byron a sympathetic figure; and Mickiewitz said with some degree of truth, "Byron is the secret tie which binds the literature of the Slavs with that of the West." Political tyranny was not the only factor in Byron's Russian popularity. It was unquestionably augmented by the contrast between the barbarism of the East and the desire for West European culture, and presumably also by the circumstance that the aristocracy, which from social position had been attracted to Byron, was the centre not only of the intellectual but of the liberal movement. ${ }^{4}$

- ${ }^{1}$ See Otto Harnack, Puschkin und Byron, Essais und Studien, Braunschweig, 1899.

${ }^{2}$ See Herzen, Du développement des idees revolutionaires en Russie, London, 1858, on - Onägen; also Mickiewitz, Vorlesungen über sclavische Literatur, Leipzig, 1843. Copious translations from Pushkin are to be had in the new anthology of Russian poetry, edited by Prof. L. Werner of Harvard.

${ }^{3}$ Alexius Batschinski, instructor in Chemistry at the University of Moscow.

4 In Greece, to judge from conversations with Athenian students in German Universities, Byron is widely read, though not widely imitated. He is remembered chiefly as a soldier, and his portrait in military costume hangs on the walls of many Greek homes. Byron's centenary was celebrated in the land of his death and scarcely noticed in the land of his birth. 
Thus we see Byron helping to shape the destinies, artistic, political and social, of European nations. ${ }^{1}$ In Byron's day conditions in America were very different. America had freed herself from whatever oppression she had endured; America was new; the hopeful national feeling born of the war of $18 \mathrm{I} 2$ was indeed contemporary with the rise of Byron; society was crude, unsophisticated, but at core healthy; Byron could not be a great social and political force. His appeal was personal and literary and this, too, usually in a bourgeoise fashion, in the Byronic pose, in the Byronic Spenserian and ottava rima, in the Byronic lyric. De Musset wore a Byron collar, but he wrote La Nuit de Decembre; Byron's American followers had little more than the collar. What was but a secondary phase of Byron's effect on the Continent, namely, Byronism in its unworthy, undignified sense, Byron travestied, appeared with us most dominant and almost alone. Indeed, the reader, who is in a general way not unfamiliar with Byron and with earlier literary America, could surmise it must have been so.

II.

Literature, especially verse, had always been in America hardly more than an intellectual exercise, yielding some facile and pleasing but lifeless work among persons of education and taste, yet more that was equally facile but utterly crude among persons of education without taste. The mob of gentlemen (and ladies) who wrote with some ease was, relative to the times, large and restless. They followed, like our early architects, ${ }^{2}$ the approved English

1 See Bibliography.

${ }^{2}$ Colonial private architecture,was based on the Queen Anne style as modified by wood ; church architecture followed Wren and Gibbs. Government buildings were small owing to insufficient grants from the Crown, but were English as far as they were anything. See History of Architecture by A. D. F. Hamlin, chap. xxvii, with bibliography on American Architecture. 
models. Cotton Mather and other "New England Elegists" 1 had imitated the conceits of Donne, Crashaw and Quarles; Michael Wiggelsworth, the jingles of Sternhold and Hopkins ; Benjamin Thompson, "ye renowned poet," had sung King Philip's war in Dryden's heroics; Mather Byles marked the new and absorbing influence of Pope, which can be traced even down to Dr. Holmes; Godfrey and Evans ${ }^{2}$ of Philadelphia refined their odes after Gray and Collins; Trumbull, Fessenden and others did clever Hudibrastic burlesques on American affairs; Dwight and Barlow polished off huge epics after Wilkie, Glover and Blackstone. Addisonian essays by Virginia planters or New England merchant kings, with lyrics to Amaryllis by Corydon and Strephon, began to adorn the now flourishing magazines. ${ }^{8}$ Examples need not be multiplied. Sometimes we note conventionality of theme, almost always, even where there is something personal or American in theme, the same self-conscious conventionality of style, ${ }^{4}$ whether inane or fustian, the same inability to find or to use one's own voice. Freneau's little lyric, "The Wild Honeysuckle," is one of the very few striking exceptions down to 1800 . There were no professional authors before the novelist Charles Brockden Brown; and the only writing combining literary finish with independence and vitality, besides that of Crevecoeur and Woolman, had been done by Edwards, Franklin, Thompson and Noah Webster in theology, biography, science and scholarship; by Jef-

1 See Elegies and Epitaphs, reprinted in " The Club of Odd Volumes," 1896.

${ }^{2}$ His "Ode on the Prospect of Peace" (1761) Kettel calls " decidedly the most finished production which the literature of our country could exhibit at that date."

${ }^{3}$ See Check List of American Magazines printed in the Eighteenth Century by Paul Leicester Ford, Brooklyn, 1889 ; and The Philadelphia Magazines, 1741-1850, by Albert H. Smyth, Phil., 1892.

"This reached its reductio in the " poems" of Phillis Wheatley, a negress caught young in the African forests, who besang Homer and addressed "General Washington" in Popian heroics. 
ferson, Madison and Jay in polemic or philosophic politics ; and their aim had not been to produce literature.

After the passing of the more somber phases of Puritanism, about I $730,{ }^{1}$ Boston, with "The Muses' Factories" adjacent, began to develop a provincial culture of which $A$ Collection of Poems by Several Hands (1744) and the Pietas et Gratulatio (I762) ${ }^{2}$ are characteristic records. But even before the Revolution, Philadelphia was outstripping her and was destined to be our chief centre of refinement for more than a generation, ${ }^{3}$ when she finally yielded to the circles represented by the Knickerbocker writers of New York and by the North American Reviez essayists, and later by "The Stelligeri," our poets preëminent, of Boston. It was a Philadelphian who seems first to have felt and voiced the ever peculiar misfortune of the American bard

\author{
Where few the muse can relish, \\ Where all the doctrine now that's told \\ Is that a shining heap of gold \\ Alone can man embellish." 4
}

William Cliffton, in some lines to Gifford prefixed to the Philadelphia reprint (I799) of the Baviad and Maviad, lamenting

"These cold shades .... . these shifting skies

Where fancy sickens and where genius dies,"

could yet rejoice that

"There still are found a few to whom belong

The fire of virtue and the soul of song."

\footnotetext{
${ }^{1}$ Cotton Mather died in 1728.

${ }^{2}$ A Harvard collection of Greek, Latin and English verse, suggested by a similar offering to the new King from the English Universities.

${ }^{3}$ See the introductory chapter on Pennsylvania in Literature of A. H. Smyth's Bayard Taylor, American Men of Letters Series, Boston, 1896 ; and A Reader's History of American Literature (p. 51) by T. W. Higginson, Boston, 1903.

"From Evans' "Ode to Godfrey."
} 
Among these few Dennie, ${ }^{1}$ founder and first editor of The Portfolio, was chief. His pseudonym was Oliver Oldschool; and he enjoyed being compared with Addison. His conservatism was characteristic of that small urban class which had the fostering of culture and the making of verse most conscientiously at heart. This was rather favorable than otherwise to Byron's influence in America.

There were also literary coteries in Charleston, New York, Boston and Hartford, and even small towns like Worcester patronized letters and gossiped on the English poets. ${ }^{2}$ And away from the cities, the rustic bard was beginning to dream and sing, while the undeveloped and untrained taste of the people at large may be judged from the inflated newspaper style satirized by "The Hartford Wits," from the floods of indiscriminate praise, mistaken for criticism, to be found in the prefaces, notes, etc., of obscure books, and from the admiration accorded to the first American Anthology, the unpromising Columbian Muse. ${ }^{3}$

A brief survey of the best American verse in the years just before Byron shows how well acquainted were the more cultured of our forefathers with current English models and standards of criticism, both the older and the newer. The above conditions, specifically American, aside, Byron had, it appears, the same literary tendencies for or against him as in England, when he awoke one morning and found himself famous. Of the American attitude toward his person, his romantic appearance and

${ }^{1}$ Cf. Moore's Poems Relating to America, "Epistle to the Hon. W. E. Spencer" with note. Dennie was the only good thing the genial Irishman found here.

${ }^{2} C f$. "The popular English works of the day are reprinted in our country; they are dispersed all over the Union; they are found in everybody's hands; they are made the subject of everybody's conversation." - W. C. Bryant, in the North American Review, July, 1818, paper on Solyman Brown's American Poetry.

${ }^{3}$ New York, 1794 ; there had been attempts at an anthology before; see Bibliography. 
life, his morals, the eccentric good and evil of his acts and opinions, I shall speak later.

The once celebrated Robert Treat Paine is interesting as a Della Cruscan. He exchanged, as "Menander," a series of effusions with Mrs. Morton as "Philenia," "a lady whose title," reads the note in Paine's collected verse, ${ }^{1}$ " to the first place among our native poetesses" was "undisputed and indisputable." Royall Tyler, over the signature "Della Yankee," satirized the fashion like Gifford.

Joseph Story's The Power of Solitude, ${ }^{2}$ with mottoes from The Seasons, The Pleasures of Memory, and The Pleasures of Imagination, with its sentimental frontispiece $^{8}$ (a hermit, book in hand, before a cave by a wooded river), opens in smooth imitation of The Pleasures of Hope and embraces in its two protracted cantos of heroics the moods, the ideas and the style prevalent in England during the latter half of the century. The moralizing, the pensive melancholy natural to the subject, appearing again in his "Monodies" after "The Graveyard School," the mild humanitarian sentimentality - he describes and mourns a country girl, seduced and deserted - the sympathy for evening and quiet, neat landscapes, the domestic pictures, the romantic pleasures in

"The mouldered turret and the moonlight main,"

reappearing in a poem " in imitation of Lewis' Alonzo and Imogene," and the interest in

"fairy tales or legendary woe,"

reappearing in an ode on "The Druid Rites," relate him by turns to Goldsmith, Akenside, Blair, Campbell, Gray,

1 Works, Boston, 1812.

2 Second Edition "with other poems," Salem, 1804.

${ }^{3}$ Engraved by J. Aiken, Newburyport. 
Crabbe, Collins, Horace Walpole, "Monk" Lewis and Anne Radcliffe. ${ }^{1}$

The Poems of Susanna Rowson, "Preceptress of the Ladies' Academy, -Newton, Mass.," though much inferior, have the same sentimentality and the same moralizing tone, while the Poems " of the late Dr. John Shaw" show traces of young "Anacreon" Moore and especially of MacPherson." As early as I786, Joseph B. Ladd had tried at Ossian; Sewall's Versions ${ }^{5}$ - Ossian in heroics was published in 1810. The Foresters of the ornithologist Wilson ${ }^{6}$ distinctly recalls Cowper; The Sylphs of the Seasons, delicate work by the artist Allston, ${ }^{7}$ reminds one somewhat of his friend Coleridge, though neither is imitative.

If the somewhat conventional older poetry was still popular, the new was absorbed here as rapidly as in England and its effects were visible at once. In The American Miscellany, Original and Selected, ${ }^{8}$ for example, we note Burns' "Wallace," bits from Paradise Lost and Blair's Grave; Shenstone's Schoolmistress, Collins' Eclogues, which, with a translation of a Turkish ode in heroics, indicates the charm already exercised by the Orient, Gray's

1 For "gruesome romanticism" in America see especially Freneau's House of Night, 1786.

${ }^{2}$ Boston, 1804.

${ }^{3}$ Philadelphia and Baltimore, 1810.

" He had begun also a poem in blank verse, "The Wanderer," to exemplify " the wild idea " that "genius was totally incompatible with prudence and that superior abilities were a full excuse for extravagance and irregularity." Though he had sense enough to abandon it, "the wild idea" is worth noting, as indicative of the new romanticism. This "wild idea" was soon to affect the Byronic bards.

${ }^{5}$ Sewall also versified Washington's Farewell Address, Portsmouth, N.H., 1798. The name of Trumbull's popular burlesque is also an indication of the popularity of Ossian as early as the early days of the Revolution.

${ }^{6}$ In The Portfolio, 1809.

${ }^{7}$ It possesses something of the imagination and terror of his painting but nothing of its massiveness.

${ }^{8}$ Philadelphia, 1807. 
"Elegy," Campbell's “Exile of Erin,” Moore's “ Ballad of the Dismal Swamp," Southey's "Complaint of the Poor," and most noteworthy, The Ancient Mariner in full. Among original poems there are "Monodies" and "Elegies" on the death of Burns, "The Prostitute," described with Goldsmith's humanitarianism and Goldsmith's numbers, imitations of Moore's lyrics and a tale of Wordsworthian simplicity on "The Idiot."1

With the birth of the national spirit in 1812 , and for a generation following, when we felt that we had justified ourselves before the world, before England especially, in politics and in material progress, the long-increasing desire for an American, for a national, literature became almost a monomania: it had been unanimously decided, says Lowell ${ }^{2}$, that we should have one. Great singers ought to be born among us to celebrate American scenery, deeds, heroes ${ }^{3}$ but they could not (it seems to have been felt by the singers, though repudiated by some of the critics) be great without winning England's approval, and without casting their Americanism, as ever before, in the moulds furnished by England. So Bryant became " the

1 The style was early parodied with us as in England. See Fessenden's skit, "Directions for doing poetry in the simple style of Southey, Wordsworth and other modern metremongers." A foot-note says: "There is an inflated species of simplicity, consisting of exaggerations of thought expressed by colloquial barbarisms, mixed with occasional pomposity of diction, which it is the object of the above to ridicule." But he is thinking especially of Southey. It is to be found appended to The Terrible Tractoration (1803), 4th Ed., Boston, 1837.

${ }^{2}$ In his review of Ward's Percival; for some contemporary documents bearing on this point, see Bibliography.

${ }^{3}$ A sensible, restrained and noble expression of the idea, which was so universally trumpeted up and down the land without sense, restraint or nobility, is this : "Why should these words, Athenian, Roman, Asia and England, so tingle in the ear? Where the heart is, there the muses, there the gods sojourn and not in any geography of fame. Massachusetts, Connecticut River and Boston Bay you think paltry places, and the ear loves names of foreign and classic topography. But here we are; and, if we tarry a little, we may come to learn that here is best." - Emerson, Heroism, Essays, first series (1841). Dwight's Greenfield Hill (1794), was an early result of this feeling. 
American Wordsworth," Mrs. Sigourney " the American Hemans." That was the highest praise. ${ }^{1}$ If the cultivation of verse had been before but an exercise, it was now a duty. Thus an increased impulse was given to talent, but no less to vanity and fatuity. Many a misguided author lamented in a prose preface our native poverty in poetry only to hint that perhaps his own would be adjudged the mighty desideratum. ${ }^{2}$ Byron was a great poet overseas, an English poet. This was itself enough to make him popular and a popular model; but there were elements in him, not always his greatest, as has been said, which, though, to a certain extent, sources of popularity elsewhere, were peculiarly fitted to make him popular and the popular model with us. Yet no one writer ever became the American Byron; Lowell said he himself knew ten, and they were in sooth legion.

But we can scarcely reason to any purpose on the phenomena without a detailed investigation. I must ask the student, bearing in mind what has been remarked on both Byron and American verse, to examine now a considerable body of Byronic material, that we may return later to our proposition, when more familiar with the facts. In the remarks on Byron in European literature, attention has been called but to names; the student's acquaintance or

${ }^{1} C f$. "The number of educated and cultivated minds is rapidly advancing and the excess will, whether it be by way of attaining a high accomplishment, of finding relief from ennui, or of earning a livelihood, devote their leisure exclusively to literature and thus become the Johnsons and the Goldsmiths, the Southeys and the Scotts, the Campbells and the Byrons of America." - Prof. George Tucker, University of Virginia, in a lecture on American Literature printed in the Southern Literary Messenger (Richmond), vol. iv., 1838.

Dearborn, the publisher of Byron's complete works (1836), was called " the American Murray." See also the Fable for Critics.

${ }^{2}$ A fellow countryman whom fate concealed by naming him Smith (Elbert H.) may be instanced. In 1849 appeared his $M a-K a$-Tai-me-she-Kia-Kiak or Black Hawk, " a national poem in six cantos," which was "dedicated to all the lovers of the arts of Poesy and the Belles Lettres and to all the friends and patrons of American enterprise and home industry." 
the possibility of his acquainting himself, has been taken for granted. Many names that must follow are either unknown or inaccessible, and those that are not will still be dwelt on for completeness. Thus I shall quote at length. 


\section{CHAPTER II.}

\section{THE BEGINNINGS. - Byron IN EARLy Newspapers aND MAGAZINES.}

OODRICH, the prolific, useful and sometime famous I Peter Parley, described in his Recollections ${ }^{1}$ the beginnings of Byronism in America, more especially in New England, as follows: "Campbell's Pleasures of Hope, and Roger's Pleasures of Memory," he says, "were favorite poems from I8IO-I 5 " and during the same period, Thaddeus of Warsaw, The Scottish Chiefs, The Pastor's Fireside, by Jane Porter, Sanford and Merton, by Day, Belinda, Leonora, Patronage, by Miss Edgeworth, and Caelebs in Search of a Wife, by Hannah More, were types of the popular taste in tales and romances. It was, therefore, a fearful plunge from this elevated moral tone in literature into the dreary if not blasphemous scepticisms of the new poet . . . . By degrees the public eye - admitted to these gloomy cavernous regions of thought - became adjusted to their dim and dusky atmosphere . . . What was at first revolting became a fascination ${ }^{8}$. . . . In about five or six years after the appearance of the first canto (sic)

1 Recollections of a Lifetime, 2 vols, New York, 1857, vol. ii., p. $103 f f$.

${ }^{2}$ He speaks elsewhere (vol. ii., p. 100) also of Scott's early popularity, saying that his sister had The Lady of the Lake by heart, and that " all young poets were inoculated with the octa (sic) syllabic verse."

3 "Comments on French society and on some of Byron's poems also show, in an indirect way, that the people were not thoroughly familiar with vice. . . . . A large part of would-be fashionable society was in the position of the college freshman who wants to be dissipated and does n't know how."-W. B. Cairns, On the Development of American Literature from 1815-1833, page 10, Bulletin of Univ. of Wis., 1898. 
of Childe Harold's Pilgrimage the whole poetic world had become Byronic. Aspiring young rhymsters now affected the Spenserian stanza, misanthropy and scepticism $^{1}$. . . . In vain . . . . the pulpit opened its thunders against them (i.e. his poems); teachers warned their pupils, parents their children. I remember as late as 1820 that some booksellers refused to sell them, regarding them as infidel publications. About this time a publisher of Hartford declined being concerned in stereotyping an edition of them . . . . Byron could no more be kept at bay than the cholera." ${ }^{2}$

The New England Galaxy (Boston) testified : ${ }^{8}$ " Everything from the poetical mint of his Lordship passes current and is bought up with little less avidity than our merchants in the China trade by (sic) Spanish milled dollars." And George Ticknor wrote in his diary: " "He (Byron) has very often expressed to me his satisfaction at finding that his works were printed and read in America - he spoke to me of the American edition of his poems ${ }^{5}$

${ }^{1}$ Every village had "its little Byron, its self-tormenting scoffer at morality, its gloomy misanthropist in song." - H. W. Longfellow, North American Review, Jan., 1832, in Defense of Poetry. For personal confessions of rustic juvenile Byronism, see My Own Story (p. 55-57) by J. T. Trowbridge, Boston, 1903.

${ }^{2}$ He says, too, that Byron paved the way for the sensualities of Paul de Kock and the deism of George Sand (!).

${ }^{3}$ In a review of Beppo with selections, date of June $26,1818$.

${ }^{4}$ See Life, dates of June 20, 21, 1815.

"On visiting the "Ontario," in Leghorn harbor, May 21, 1822, Byron found in one of the officer's rooms a copy of the New York edition of his poems. "He took it up with every appearance of pleasure and seemed to interpret it as an earnest of his fame." George Bancroft, History of the Battle of Lake Erie and Miscellaneous Papers, N.Y., 1891. Byron speaks several times in his diaries and letters with similar feelings of his American reputation; he at one time cherished the hope to visit America (see "Ode to Venice").

From this volume I will transcribe a little-known anecdote characteristic of Byron's popularity and gallantry, as well as of the American lady abroad. This same day Byron also visited the frigate "Constitution." "One lady of great personal beauty put out her hand, and saying, "when I return to Philadelphia my friends will ask for some token that I have spoken with Lord Byron,' she gently took a rose which he wore in the buttonhole of his black frock coat. He was pleased with the unaffected boldness and the next day sent her a charming note and a copy of Outlines to Faust as a more durable memento." What became of the rose, the note, and the Outlines, I cannot say; but the copy of Don Juan, which Byron, a day or so later, gave to Bancroft, is now in the Lenox Library. 
which I had sent him." Though deprecating his English Bards, "he did not express the least regret when I told him that it was circulated in America almost as extensively as his other poems" . . . . "Byron wondered," moreover, "that our booksellers could find a profit in reprinting the Hours of Idleness." These explicit contemporary documents may well introduce the evidence below.

For the earliest beginnings one must go to the newspapers and magazines. Apart from some news of the day and local matter, one will find there innumerable translations from the Greek Anthology and Horace, original Latin verses, heroic epistles to this or that forgotten worthy of Boston, New York or Philadelphia, spring poems of many a youth "who has just passed his seventeenth birthday," excerpts from and imitations of the British poets - Shakespere, Milton, Waller, Pope, Southey, Moore, Campbell, Burns, being, perhaps, the most popular - and paragraphs from " unpublished poems read before the X- Literary Society," with perennial " Fourth of July Odes." 1 Relatively more space seems then to have been given, in the newspapers, at least, to poetry, while the magazines differed especially in their dependence on England, on her books ${ }^{2}$ and periodicals, for ideas and material in both prose and verse..$^{3}$ One notes that the reading public was less interested in the daily news and more confined to the upper classes; but the display of learning proves nothing for superior culture. On the con-

\footnotetext{
${ }^{1}$ There are two signed "Mr. W. C. Bryant" in the New England Palladium, July, 1814-15.

${ }^{2}$ The shameless activity of the pirating book-trade precludes an explanation on the ground of relative inaccessibility of complete editions of new works.

${ }^{3}$ Analogous to-day is the relation which the German-American press with its 600 newspapers and magazines bears to that of the Fatherland. Analogous, too, is its constant reiteration of its unhappy dependence.
} 
trary, the Greek translations were, apparently, college exercises, from that once famous text book, the Graeca Majora, while the Latin verses were often incorrect where they were not filched direct from the college classics.

Byron's name and influence appear soon, and with ever increasing frequency. We can trace Byron in book reviews, book-sellers' notices, in poems " addressed to his Lordship," in extracts from his works, in direct imitations and in quantities of verse, merely hinting of Byron. These elements may be presented in order.

The earliest reference, which has come under my notice, is in the Portfolio (Phil.) for March, I809. It is a single page review of the Hours of Idleness. One would observe with amusement to-day that it follows directly upon a review of Wordsworth's Poems where the apostle is said to have "mistaken silliness for simplicity." A word may be quoted:- "George Gordon, Lord Byron, the author of these poems, had not at the time of their appearance completed his twentieth year. Many of them are written with spirit and force; some with much sweetness" - the critic then admits defects of versification and grammar, but pleads for the youth of the poet. Two selections are appended. ${ }^{1}$ In May, I8II, is a twelve-page original $^{2}$ review of the English Bards. It speaks of Byron as one of Gifford's retainers and sworn foe to Jeffrey, reviews his quarrel, alludes to his Lordship's being on his travels, and speculates on "what will be the issue of a challenge so unequivocally invited," when the defiant young bard comes back. Though it disapproves of the scurrility, it admits the "bold, honest and manly indignation" and discovers " in the youthful countenance of the

1 "O had my fate been joined with thine," and "Lachin y gair."

${ }^{2}$ Many reviews of Byron were copied bodily from English periodicals. 
poet the large temporal vein of genius." Very high praise is given to Byron, both as a man and a poet, for the now famous passage on Henry Kirk White, which is reprinted in full. This coming so early is noteworthy: it marks right at the beginning of his career an interest in his personality and affairs ${ }^{1}$ and a genuine appreciation of his performance. We may turn over some subsequent volumes of the Portfolio. In the number for February, 1813, Childe Harold is briefly noticed (one page). In view of the above citation it does not surprise us to read:- "Lord Byron was, before he left England, unquestionably in the very first class of British poets of the present day, and Childe Harold will not only sustain but increase his reputation." But from this it may not be unjust to infer that the poem did not take America so immediately by storm as it did London. Goodrich finds the reason in Byron's being a lord and a man of fashion, for here, says the good democrat, "these adventitious attributes were less readily felt and therefore the reception of the new poem was more hesitating and distrustful." ${ }^{2}$ The Portfolio of December, $\mathrm{I}_{8 \mathrm{I}} 3$, and January, $\mathrm{I}_{8} \mathrm{I}_{4}$, transcribes the whole of The Giaour. The number for July, I8I4, reviewing The Corsair, remarks, "The most fashionable writer now in England - and the fashion there is always sure to be the fashion here-is Lord Byron." Then, "Mercy on us what an amateur in robbing and throat cutting this young nobleman must be." The critic does not take it

1 How minute this grew we see from the Portfolio, May, 1819. A "Literary Note" says:- "The Liverpool Messenger announces that a new poem from the pen of Lord Byron has been sent to England, but the title or subject it has not been able to ascertain." A word under "Latest from Europe," in the New England Palladium for April 16, 1824, says :- "Lord Byron has subscribed $\$ 45,000$ to Greek loan fund." This is especially significant, for communication with Europe was then very irregular and only the most important events were chronicled. "The new poem" must have been the first two cantos of Don Juan, finished Jan. 20, of that year.

${ }^{2}$ Recollections, vol. ii., p. 100. 
seriously : " it is written ad captandum volgus," and Lara he burlesques condescendingly in his prose critique by dashes, ejaculations and incoherence. Coming down to October, 1822 , we observe a different tone ${ }^{1}$ of certain "Lines to my Daughter," we are told that they are "wholly free from that daring wickedness and loathsome licentiousness which distinguishes the head of the Satanic School," and one does not wonder, for they are spurious. ${ }^{2}$ Byron's dramas received less critical attention; ${ }^{8}$ Don Juan is first criticised in $1823^{4}$ as " a terrible poem for youthful readers," the work of a "titled profligate" and "licentious bard." The "sneers at that character on which in the female sex the happiness of life depends, a virtuous and modest woman," are dreadful; and "how could anyone impiously write and print two such lines as these :-

' ' $\mathrm{T}$ is strange the Hebrew noun which means I am

The English always use to govern damn?", 5

Consistency was a jewel not always worn by Byron's American critics. ${ }^{6}$ The reviewer prognosticates in con-

1 The editorship had meanwhile changed hands and Byron had begun on Don Juan.

2 " How many insipid, gross and pitiful productions have been read and admired, quoted and lauded by our sagacious and discriminating wits, merely because the title page supposed them to be from the pen of "my Lord Byron." "-Preface to American Bards (a satire) by G. H. Worth, 1819. The place of publication is not given, but as a contemporary newspaper critic of Boston advised the author to "keep his poetry on the other side of the Delaware" we may infer it was old Philadelphia. In England the only poem of merit ever fathered on Byron was Wolfe's "Sir Charles Moore."

3 e.g. Sardanapalus, Dec. $22,1822$.

${ }^{4}$ But for March, 1822, parallel passages from Don Juan, the shipwreck (ii., 27ff), and from its source Shipwrecks and Disasters at Sea had been given in full to indict Byron of plagiarism.

5i. 14.

${ }^{6}$ The American Monthly Magazine and Review i., 442 (New York, Oct., 1817), discussing The Lament of Tasso, makes use of such terms as gross, despicable, base, heinous, condemns it as worthless and - prints it in full, $c f$. Cairns, p. 16. (Cairns observes that this magazine was anti-English, and that the tone of American criticism toward Byron was determined largely by the editor's attitude toward England and English writers.) A magazine for ladies, The Literary Cabinet iv., 25, (New York, 1821), in reviewing Marino Faliero, calls Byron " that great poet whose writings have given such a high character to the genius of the age," this, too, after Don Juan had been so long shocking the ladies. 
clusion, like Southey, " the most dreadful but yet unavailing torments of his death-bed." But in r825 the editor finds space for a letter defending Byron's character, urging us to be grateful for " his frequent and eloquent reflections on America," ${ }^{1}$ and other notices were not always so harsh. ${ }^{2}$ The North American Review ${ }^{3}$ thought Childe Harold and Don Juan " masterpieces respectively in the serious and comic order."

Excerpts from Byron filled the literary corners of the newspapers for a generation. Bits of Childe Harold follow directly in the year of its publication; the same holds for his other poems, though much less for the dramas. The minor poems were very popular, even those now little read; ${ }^{4}$ but one wonders that so much is what time has since proved his best. Noticeable, however, are the infrequent excerpts from Don Juan; they are, generally, strictly poetical, ${ }^{5}$ or such as contain friendly references to America and Washington.

Though contemporary poets were often extensively criticised and quoted, Byron's name is by far the most ubiquitous in all the newspapers and magazines examined, and it may be assumed that the points of view varied, much as in England, and were often subservient to England.

A curious side-light on Byron's early popularity is cast by the booksellers' announcements. One instance must suffice. The $S p y$, a weekly of the then provincial town

${ }^{1}$ e.g. Age of Bronze, v. and vii.; "Ode to Venice;" Childe Harold iv., 96; "Ode to Napoleon."

${ }^{2} C f$. The Western Review (Lexington, Kentucky), vol. ii., 6, 1820; and the Cincinnati Literary Gazette for 1825.

${ }^{3}$ Byron's Poems, A. C. Everett, vol. xx., p. 1-47.

"As the "Stanzas to Cadiz," the epitaph on his Newfoundland dog and the epigram on the sixth anniversary of his wedding. $C f$. the uncollected verses of Kipling that were so numerous in the year of fame' 98 .

"As "An infant when it gazes on the light," "T is Sweet," and "Ave Maria." 
of Worcester, Mass., carried the advertisements of one George A. Trumbull. - In I8I 2 he caused to be announced "Rokeby, by Walter Scott, \$1.00;" "Childe Harold's Pilgrimage and Other Poems, by Lord Byron, 75c.;" "The Corsair, from the fifth London Edition," is announced in large type as a specialty in the issue of July 20, I8I4; others follow in due season. All were, of course, American reprints. This Trumbull had also for sale "Bottles of Volatile Aromatick and Head Ache Snuff, accompanied by Dr. Waterhouse's certificate." Such were our venders of poetry and culture.

To leave the critic with his pen, the editor with his shears, and the bookseller with his bottles, the public's views and feelings may be guessed at from the many poetical addresses to his Lordship, and from the ever swelling flood of Byronic verse. As to the former.

In the New England Palladium (Boston) for October 6, I815, one discovers "Lines suggested by the closing stanzas of Byron's Childe Harold." Byron is addressed as "sweetest bard," "latest of bards," and praised for his singing of Greece and Athens. Most to the purpose, however, is this :-

\footnotetext{
"For to weep with thy grief, and to smile with thy joy To follow thy thoughts thro the mind's darkest storm, Bespeaks not a spirit of earthly alloy,

But a soul that was cast in a heavenly form."
}

Thus self-conscious versifiasters laid the flattering unction to their souls, and thus the pose, the fad, began. The Worcester $S p y$ for July 27, I814, contains an "Epistle to Lord Byron," nearly a column long. It opens :- 
And then reviews his career:-

"We saw when thou thy vengeance hurled

On Jeffrey and his lawless clan

Which changed the 'minor'1 to the 'man'"-

Lo,

"Thine is the path where danger lurks

Mongst ruthless Giaours and pagan Turks

Thou, like thy Corsair, ${ }^{2}$ bold and free,

Delight'st the thunder cliffs to ride"-

yet it laments that his heroes are

"such a savage band

With each a war knife in his hand"-

And alas !

"the fair thy tales delight ${ }^{3}$

And beg your Lordship still to write."

It concludes admonishingly :-

"O Byron, let not love of fame

Extinguish virtue's brighter flame;

Who thus can lead our minds away

Should ne'er to doubtful paths betray,

But still unchanging keep in view

Their pleasure and their safety too."

The author of this Horatian precept of utile dulci seems to have had a presentiment of Don Juan. The Portfolio for December, I8I7, yields another "Epistle to Lord Byron;" it attacks him in two columns of fine print for making poetry and capital out of his woes, just as

"the mendicant protrudes to sight

His mangled limbs our pity to excite."

\footnotetext{
${ }^{1}$ A recondite allusion to the title page of the Hours of Idleness and to the comments thereon in the Edinburgh Review.

2 The Corsair had just been put on sale in Worcester. below.

${ }^{3}$ Cf. "Every puling miss thy story greets," "Address" in the Portfolio, quoted
} 
and for cynicism and libertinism. It, too, concludes admonishingly, or rather beseechingly:-

"Misguided spirit! yet in mercy spare,

And if thy heart be human, $O$ forbear!"

Byron's melancholy and perversity were considered distinguishing traits. ${ }^{1}$ No English poet received so many epistles from across the sea, except, possibly, Mrs. Felicia Hemans, who came nearest to rivaling his Lordship in popularity, judging by the press, from about the year 1826. ${ }^{2}$ The odes and elegies called forth by his death will be mentioned below.

The imitations were sometimes serious parodies, as one in the Palladium, July 9, 1816, in answer to "the questionable spirit which pervades the too popular 'Fare Thee Well," where Lady Byron sobs :-

"Now each tie of love is broken"-

an American defence which culminated later in Mrs. Stowe $;^{3}$ or sometimes burlesques, as one in the Galaxy, January $26,1826-$

"There was a sound of rioting by night" -

where some local Boston escapade supplants Waterloo. But they were oftener "in the manner of Lord Byron," as the subtitles occasionally read. Lyrics predominate, and all, save those to which Moore or Campbell are also (1819).

${ }^{1}$ Cf. " Black wormwood bitters Lord Byron should bear," in the "Croaker" Poems,

${ }^{2}$ The first American Edition of Mrs. Hemans was prepared by Andrews Norton, and published in 1826.

${ }^{3}$ In 1869, in the Atlantic Monthly; there had been in the same magazine eight years before a sensible defense of Lady Byron by Harriet Martineau. 
party, ring the changes on love and despair. Indeed, about 18 I5, newspaper verse grows decidedly more melancholy; verses "On a Chilling Thought" after Byron's "To Inez," on "Grief" in Spenserians, on "The Scenes of my Youth" by "Philander" (where we have Byron and the Della Cruscans) from the Palladium for I8I5 show a marked contrast to the eighteenth century verse that still sometimes accompanies them. The new verse makes, too, more of an attempt at directness and passion, though universally ridiculous :-

"And is the love of one whole year

So sudden and forever gone -

$\mathrm{O}$ then farewell to me still dear,

Still dear to me art thou alone."

In 1829, in the Essex County Gazette, one may read of the

"Girl of the dark and kindling eye!

who suggests

"The funeral touches of decay,"

which suggest, in turn

'" The pure and blessed light of heaven."

The piece is signed J. G. W., and is one of many, as yet uncollected, ${ }^{1}$ Byronic lyrics of the Quaker Poet. Whittier's early verses were frequently copied in other papers. He was one of the most popular of the Byronic American bards, but Byronism was, as his latest biographer ${ }^{2}$ has said, "completely foreign to the quietism of his early training and of his later feelings," and seems to have been due " to the disturbing stimulus of the new and larger world

1 But see Cheever's Commonplace Book of American Poetry.

${ }^{2}$ George R. Carpenter, in American Men of Letters Series, Boston, 1903. 
to which he was yet imperfectly adjusted." It forms but a very minor phase of Whittier's literary history. ${ }^{1}$

The Byronic weariness of life was widely cultivated; it bespoke, presumably, even more than love's delirium "a spirit not of earthly alloy," it had an air of something deep about it, something, too, that set the author apart from his happy-go-lucky fellows. So sings a youth for the Charleston Courier, in 1825:-

"At nineteen, life began to pall-

With love and beauty I had done,

Ambition, too, began to fall

From its high hopes of twenty-one."

Byron had said in the Hours of Idleness:-

"Weary of love, of life, devoured with spleen

I rest a perfect Timon, not nineteen."

The reader shall be troubled further with but the one following stanza; the remaining he can find by turning to

${ }^{1}$ For his other early Byronic verse, of. Mogg Megone (commenced 1830). Whittier said later, "It suggests the idea of a big Indian in his war-paint strutting about in Sir Walter Scott's plaid." It suggests just as surely the Byronic hero and melodrama and rhetoric, e.g.,

" He starts - there's a rustle among the leaves:
Another - the click of his gun is heard!
A footstep, - is it the step of Cleaves,
With Indian blood on his English sword?"
or :-
"And how, upon that nameless woe,
Quick as the pulse can come and go,
While shakes the unsteadfast knee, and yet
The bosom heaves - the eye is wet-
Has thy dark spirit power to stay
The heart's wild current on its way?"

In the appendix to the Cambridge Edition are some Spenserians on "Benevolence." Byronic in laudation of freedom and in ottava rima is "To a Poetical Trio in the city of Gotham" (1832), mingling jest and earnest; the latter dominates, it being Whittier. $C f$. Carpenter's Life, p. 94ff. 
the New England Palladium for Tuesday, December 2, I821 :-
"Nay sigh not - 't is useless - O I could sigh too If I knew any service that sighing might do. Nay sigh not-' $t$ is better to smile if we may And thus of our pilgrimage cheat the long day. We must on, be our path over flower or thorn, Do thunder clouds gloom it, or sunbeams adorn, We must on - and it leads us all to one spot Where our pleasures, our sorrows alike are forgot."

The Hebrew Melodies set country parsons early at work on "The Destruction of Sodom," "Jael" and the like.

The tales were imitated in such papers as gave a column or two to the local poets. A youth in the Vermont Messenger for 1822 depicted in two and one-half columns "The Pirate," arousing our curiosity and fear quite at the beginning with

"Why is that form of secret woe?"-

Byron had penetrated to the Green Mountains. The Galaxy for 1837 has two columns of octosyllabic and pentameter couplets on "The Pirate Barque" -

"A tale of horror and despair" -

to quote the concluding line. For the same year it prints also "The Idiot Son" in the style of Mazeppa, and "The Lovers of Scio" in that of The Corsair with Byronic names, "Leila" and "Haja." It is only by going beyond the beginnings that the tales meet us very frequently in the papers. The lyrics on the other hand decline.

Childe Harold appears in the Galaxy for 1820 in five Spenserian stanzas, labelled "Childe Harold in Boeotia," with echoes of the second canto; The Rev. T. H. Clinch has several on "Music" in echo of the fourth. Don Juan is reflected curiously in the Galaxy for 1826 (and fre- 
quently elsewhere) as a "Carriers' Address," containing allusions to contemporary events. But neither of these longer poems was so often imitated in the papers.

Byronic echoes are audible in the many verses on Modern Greece, in whose struggle America is known to have-taken a lively interest, in odes to Napoleon, in those verses, of course, addressed to Byron, and in the odes to Lafayette in I824, who for a few weeks seems to have put all other themes at a discount.

Then Lord Byron died at Missolonghi. In England it was as if the sun had gone out, and Carlyle wrung his hands, and the boy Tennyson walked into the yard to trace with a stick in the sand, "Byron is dead." The English and Continental press made him the subject of the hour, and published countless worthless monodies in his honor. Equally great was the shock in America, and equally countless and more worthless the monodies. Though some papers, devoted exclusively to news, merely mention him under the nonpareil column of "Latest from Europe," ${ }^{1}$ and many others content themselves with long transcerpts of English critiques and verses, ${ }^{2}$ an equal number contain much and original matter. One has but to turn to our files for $183^{2}$ or $185^{\circ}$, the years of Scott's and of Wordsworth's passing, to see how very unusual was this homage of attention to a great English man of letters. The North American Reviezu begins a fifty-page review ${ }^{3}$

${ }_{1}$ e.g. "By the ship Euphrates at N.Y., from Liverpool, papers to May 25 have been received . . . . Lord Byron died at Missolonghi, April 19, of a rheumatic fever, . . [a few biographical facts here] . . His last thoughts were of his wife, child and sister. His Lordship was in his 37 th year and is succeeded in his title by Capt. Byron of the navy."

${ }^{2} C f$. The Galaxy, July 2, 1824:- "The English papers contain a great number of notices of this nobleman's life, character and works, from which we have extracted the following ;" here follows a column of biography and criticism.

${ }^{3}$ By A. C. Everett. The North American Review has in succeeding volumes many articles on Byron, $c f$. Index to North American Review 1815-1877 by William Cushing, Cambridge, 1878. The earlier volumes (vol. i., 1815,) often reprinted passages of his poetry. Cf. esp. vol. iv., 369-377, selections from Childe Harold, iii. 
of Lord Byron's poems :- "The death of Lord Byron, without depressing the price of stocks or affecting the election of President, has produced a deep and general feeling of regret throughout the country." Most articles and notices, however, refer more to his life, especially in the Greek war, than to his poetry. That he was a nobleman, an AngloGreek Washington and a poet to boot, seem to have been for the moment uppermost in the public mind. The funeral criticism on his poetry, though often extravagant either in blame or in praise, sometimes surprises us by its soundness. "In depth of thought, in power, in brilliancy and felicity of style, in his almost miraculous facility of production, he stood without a rival in our day. . . . . He has two defects, extravagance of thought and language, and want of care and finish in the versification. . . . Childe Harold is the poem on which his fame will ultimately rest . . . . the moral defects of Beppo and Don Juan are to be regretted. . . . . The general effect of his writings is immoral," are characteristic bits from Everett's review.

Of home-made monodies let the following selections suffice. In the Galaxy, July 16, 1824, Byron is praised for his poetry, reference being all to the third canto of Childe Harold as "ye mountains of Jura" and "thou, Lake Leman" - but what touched the writer was that

"Though far from his home and his country he died, Yet the loud voice of freedom has hallowed his tomb;"

it concludes :-

" He has left a bright name that no refluent tide Can sweep from the earth till the day of its doom." 
The same paper for August 6, I824, prints "An Ode to Lord Byron," which is one long painful column of stanzas supposed to be modelled on those of the "Ode to Napoleon," all in praise and sorrow. It has for February 26, 1826, another by the Rev. C. C. Colton, also after the "Ode to Napoleon." He "prizes," " mourns" and "blames" the poet, and shows an astonishing familiarity with his work, a familiarity which seems to have been but too characteristic of those who were trying to climb Mount Parnassus with one foot and Mount Zion with the other. ${ }^{1}$

If one institute for comparison's sake a brief examination of the newspapers from 1824 down to $\mathrm{I} 860$, one will find Byron gradually losing ground. To judge from the Boston Recorder and a few others for $1845-6-7$, he has fallen off very much - while excerpts and imitations of Felicia Hemans, pious temperance lyrics from the workshop of the once honored Rev. W. B. Tappan, and sentimental musings of Mrs. Sigourney, with anti-slavery verse signed J. G. W., are numerous. About the same period Thackeray's “ Ballad of Bouillabaisse," Browning's "How they Brought the Good News," parodies of Hiawatha, here and there a bit from Tennyson, all in the Boston Post, suggest, too, the passing of Mrs. Hemans.

${ }^{1}$ Cairns observes, "The remarks on his death from the pulpit are an interesting study." He was reviled as seducer of women, and blasphemer against the Most High; his end was dwelt on with pity and relish, while good Dr. Lyman Beecher generously lamented that Byron had not come under his own particular care and thereby received peace and the hope of salvation. For a generation thereafter Byron figured prominently in clerical " Lectures to Young Men," as atheist, libertine and inebriate. Undoubtedly the pulpit did only less than the press to spread information about Byron and to stimulate the reading of his poetry. Cf. "One reason, beyond question, which contributed to make the works of Lord Byron so popular, was the overcharged denunciations which were at first rung against them." Western Monthly Review, Cincinnati, vol. iii, p. 648, 1829.

The more dignified journals of the religious press contained but brief obituary notices. 
Of magazine articles it may be mentioned that Shelley, ${ }^{1}$ Wordsworth ${ }^{2}$ and Keats, ${ }^{3}$ seem to have claimed more and more attention. Of magazine poetry little has been said, since the bulk of it was republished in book form, and must now be looked to; for the more ambitious were not content with the Poet's Corner.

${ }^{1}$ Shelley's name appears early, linked with Byron's, as anathema. Little seems to have been known of his poetry before the Philadelphia reprint of Galignani's Edition of Keats, Shelley and Coleridge, in one large volume. See The Poe-Chivers Papers by Prof. Woodberry in the Century, 1902-3.

${ }^{2}$ Wordsworth had had from the beginning, besides Bryant, "supporters two or three." Longfellow noted in the article before quoted "how inevitably those who have imitated him have fallen into his tedious mannerisms." See "The Lynn Bard," Alonzo Lewis (Poems, Boston, 1831).

8 The New York Mirror for Aug. 22, 1829, quoting from the Boston Mercury a short article on Keats, remarks, "As yet only a small portion of the public is acquainted with his writings." 


\section{CHAPTER III.}

BYRON'S LITERARY INFLUENCE, 1815-1830.

$\mathrm{IT}^{\mathrm{T}}$ HAS been already remarked that Byron's influence on America's greater poets has never been of moment; Whittier, Longfellow, Holmes, Lowell, Emerson, Whitman, are in one way or another, indeed, distinctly unbyronic. ${ }^{1}$ Here literary influences are often obviously Continental or not contemporary. Longfellow brought us the romance and meters from the North and South of Europe; Lowell was a combination of shrewd Yankee, classical scholar, critic, statesman and professor, in whose poetry one may sometimes trace Keats ; ${ }^{2}$ Emerson's poetry is in thought reminiscent of post-Kantian philosophy, in style often of the later Elizabethans; Holmes had somewhat of the French spirit, partially temperamental, partially developed or acquired during his early years of study in Paris; he also combined the English literary traditions of the eighteenth century in his wit, didacticism, urbanity and balanced heroics; Whittier in manhood spoke his own language, though, as reformer, he had the invective and indignation of the Hebrew prophets, and, as artist, he sometimes took hints from Byrant, Longfellow, and later even from Browning and Tennyson; Whitman's antecedents are still in doubt. Poe and Bryant will be mentioned later.

\footnotetext{
1 Whitman had even more of egotism than Byron, but he made it a philosophic principle: "What I shall assume, you shall assume" (Leaves of Grass); while Byron stood "among them, but not of them"- the very reverse attitude.

${ }^{2}$ Lowell's early poems show his reading in Tennyson, Shelley and Landor. His ode to France is after Coleridge.
} 
But there is a group of men, often not without ability, whose verse, once widely read and admired, has much of Byron's spirit and technique. Though imitators, many of them by a slight infusion of personality and imagination, and by relatively skilful handling of the poems imitated, may still command some respect, and are still not altogether forgotten. All may be considered as belonging to American Literature, if we use the magnified scale adopted by Professor Trent. These it seems best to look at together, before turning to the huge mass of absolutely forgotten and poetically worthless exploits in Byronic poetastry, from which, however, we are likely to gain our chief knowledge of the kind, the extent and the causes of Byronism in America. The latter may be treated primarily with reference to facts and principles illustrated. For the former a chronological presentation seems most feasible.

Names may be grouped either side of the year 1830 . The best work of our earlier poets, of Halleck, Drake, Dana, Bryant, was then done ${ }^{1}$ the later poets were just beginning to be heard. Several things by Longfellow appeared in Poems Selected from the United States Literary Gazette, as early as 1826. His first book, albeit an elementary French grammar, bears date of 1830. Attention has already been called to Whittier's early newspaper verse. In 1827 , '29 and ' 3 I, Poe published his earlier poems. Moreover, 1827, '30, ' 32 mark the years of Tennyson's first volumes, and the rise of a new poetry in England, which was soon to affect America. By 1830, too, our social conditions had begun to approach those we know to-day. New England changed from an agricultural and

\footnotetext{
${ }^{1}$ Contemporaries seem to have felt the end of a poetic period about this time. The Knickerbocker Magazine for November, 1838, says tragically: "Our poets one by one have passed away. Halleck, Percival, Bryant and Dana, where are they?" Note, incidentally, that Kettel's three volumes of American verse were published in 1829.
} 
sea-faring to an industrial people, the movement West was beginning, and the hustling American, satirized in Martin Chuzzlewit, reached a useful maturity. Railroads and telegraphs followed. ${ }^{1}$ In 1830 we had but eight hundred and thirty-two newspapers, in number not double that of the German-American newspapers to-day, while the next decade brought the rise of modern journalism. The $N e w$ York Herald was founded in 1835 , the Tribune in $184 \mathrm{I}$, and in $185^{\circ}$ there were two thousand five hundred and twenty-six newspapers, in 1860 four thousand and fiftyone. $^{2}$ The systematic effort to spread the good, the true and the beautiful, as witnessed, respectively, in societies for various reforms, in library, college and lecture foundations and learned associations, and in art museums and academies, comes more and more into intelligent and zealous hands. Before 1830 existed, indeed, the Massachusetts Temperance Society, the American Tract, Bible and Peace Societies, the Boston Atheneum had been founded in 1806 , the American Educational Society in 1815 , the Mercantile Libraries of Boston and New York in 1820 , to be followed by that of Philadelphia in 1823 , and the National Academy of Design in 1826 ; but the anti-slavery Society (I83I) and Transcendentalism (The Dial, I840-44), such foundations for the advancement of learning and the dissemination of culture as the Boston Academy of Music (1833), the Lowell Lectures (1839), the Smithsonian Institute (1846), the American Association for the Advancement of Science (1847), the Astor and the Boston Public Libraries (both 1854), and the Agassiz Museum at Harvard (1859), with the public art galleries and the rise of church architecture $^{8}$ belong in the succeeding period, and mark

1 The Baltimore \& Ohio R.R. was begun in 1828; The Morse telegraph, 1844.

2 See Hudson's History of Journalism and Whitcomb's Chronological Outlines.

3 Trinity Church, designed by Upjohn, and Grace Church, by Renwick, were erected in the early forties. 
a more thorough-going, more independent life of the spirit. Our long apprenticeship to the learning and art of other lands was drawing to a close. ${ }^{1}$ Byronism in America, almost always in its best estate somewhat shallow, found its disciples more and more exclusively among the minor literati.

$$
\text { I } 8 \text { I } 5-1830 \text {. }
$$

Among New York authors in the early days was Gulian C.Verplanck, remembered as an editor of Shakespere. ${ }^{2}$ In I8I9 he published The State Triumvirate, a Political Tale, and The Epistles of Brevet Major, Pindar Puff. The Tale is in octosyllabics, The Epistles are in heroics, and the critical apparatus is after Martinus Scriblerus. Thus, it is interesting as being transitional. The new literature is criticised in the form of the old. Prudence is called upon to

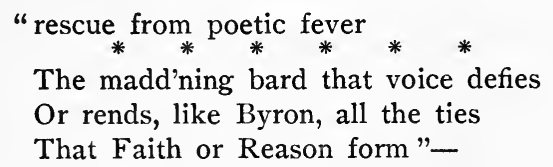

but in an "Appendix" we are furnished with a bogus extract of nine stanzas from the fourth canto of Don Juan, which in reality had not yet appeared. It deals with New York politics and society.

But Fitz-Green Halleck is a more important name. In this same year, when he and Drake were sending their "Croaker" poems to the New York Evening Post, was printed the first edition of Fanny. Few nowadays read Fanny, but any one will recall Lowell's characterization,

$$
\text { "a pseudo Don Juan }
$$

With the wickedness out that gave salt to the true one." 8

But this is a little misleading, as Beppo furnished the

${ }^{1}$ Emerson, The American Scholar, 1837.

${ }^{2} \mathrm{He}$ is generally called the first American editor, but this honor belongs to Dennie.

3 The Fables for Critics, 1848. 
original impulse. ${ }^{1}$ "It was so popular that the publisher gave him $\$ 500.00$ to add fifty stanzas to the new edition " 2 (I82I). A social satire on a flashy New Yorker and his fashionable daughter, with digressions innumerable on Greece, European politics, bad literature and bad statues, and civic life

\author{
"from Clinton down to the bill-sticker \\ Of a ward-meeting "-
}

with quizzical remarks on a lady's age, with whimsical rhymes and clever anti-climax, and quite gentlemanly ease, it is the first and the best of the sort in America. For the crim-cons of Don Juan is substituted a financial failure, while the wickedness is suggested by occasional stanzas consisting simply of asterisks. ${ }^{3}$ Bits of serious poetry are interspersed, as the stanzas on Weehawken, ${ }^{4}$ with Byronic echoes of "forest solitudes" and "crags," and of

"the moan

Of wearied ocean when the storm is gone."

But the songs recall Moore. Let cxxi serve as a specimen. The ottava rima has been docked to six lines:-

"In all the modern languages she was

Exceedingly well versed, and had devoted

To their attainment, far more time than has

By the best teachers lately been allotted:

For she had taken lessons, twice a week

For a full month in each, and she could speak,

French and Italian," 5 etc.

${ }^{1}$ Frederick S. Cossens, in A Memorial of Fitz-Green Halleck (1868) states : " Halleck told me that Fanny was published before Don Juan had crossed the Atlantic, and that he had adopted the versification of Beppo, one of Byron's minor poems." General J. G. Wilson, Halleck's friend and biographer, made a similar statement to the present writer. But see infra.

2 The New York Tribune, May 15, 1877.

3 Some older expurgations from Don Juan strike one as peculiar. Halleck's edition prints the worst things in full, but eliminates, e.g., i. 131, on the pox, and xi, 57 and 58, which contain mere jesting on the Rev. Rowley Powley and Pegasus" "psalmodic amble."

Stanzas 94-99.

${ }^{5}$ This reminds one very much of the description of the Lady Inez, Don Juan, i, 13 and 14. but it is in the earlier (1819) edition. Another passage suggests the favorite "'T is sweet." These can hardly be coincidences; Halleck's memory may have failed him and Don Juan may have come into his hands during the progress of the poem, though, as he said, Beppo set him at it. Fanny was published in December. 
Fanny is, however, not written in the tone of Don Juan. "Halleck was never cynical in his satire, and Byron always was," said Bryant ; ${ }^{1}$ and Bayard Taylor ${ }^{2}$ called him " The brave, bright and beautiful growth of a healthy masculine race," adding "The cries and protests, the utterance of 'world-pain,' with which so many of his contemporaries in Europe filled the world, awoke no echo in his sound and sturdy nature."

In certain Spenserians on "Wyoming" both Campbell and Byron are traceable in stanza and phraseology, while the subject itself had been sung by Campbell, to whose poem thankful reference was then frequent in America. "Marco Bozzaris" reminds one of Byron by enthusiasm for Greek freedom, and of Campbell in martial vigor, while its octosyllabics are echoes of Scott. There is Byron in eleven ottava rimas on "Connecticut." Here, too, as also in Alnwick Castle, grave and gay are whimsically mixed, after Byron's later manner. In "The Recorder" is a joke direct out of The Vision of Judgment: ${ }^{3}$ -

\section{"I take the liberty of asking Permission, Sir, to write your life With all its scenes of calm and strife, \\ A poem in a quarto volume."}

The New York Tribune once observed," " Halleck was of the school of Scott, Campbell and Moore, and its only American representative;" Byron's name must have been implied, or its omission was a curious oversight. Yet we feel original force in Halleck, differing rather in degree

${ }^{1}$ In Some Notice of the Life and Writings of Fitz-Green Halleck, read before the New York Historical Society. 1869.

${ }^{2}$ In an Address for the formal dedication of the Halleck monument at Guilford, Conn., July 8, 1869, printed by Amermann, Wilson, N.Y., 1877.

3 Stanza 99.

4 In the article of May 15, 1877. 
than in kind from Byron's force, which raises him above mere imitators. The critic $^{1}$ who claimed for him the energy "to seize the passing moment, the present scene, the grand event, and make them subservient to use," hit unwittingly on Matthew Arnold's analysis of Byron's peculiar genius." Halleck in remarking he felt that he had "lost on Byron's death a brother," and in long enthusiastic labors at editing the first worthy edition of his poetry and prose, may have been prompted by an intuition of kinship. Contemporaries observed it, ${ }^{3}$ at least, and one declared Halleck to be "what Byron might have been had he been born a Connecticut Yankee," 4 with an implication of a certain intellectual strength and shrewdness common to both. Still it will not do to call Halleck " the American Byron."

His friend Joseph Rodman Drake (I795-I820) left little beside The Culprit Fay and "The American Flag." Some Spenserians lamenting the dearth of American singers on American subjects, and advising Halleck as a patriotic exercise,

"To climb the palisado's lofty brow,"

are in the rhetorical vein of the stanzas on Greece in Childe Harold. A fragment, "Leon," in heroics, was inspired by The Corsair.

William Cullen Bryant used to be called " the American Wordsworth" until it was protested that this

"was endangering the life of your client

By attempting to stretch him up into a giant."

We have Bryant's own testimony on the effect first ac-

1 William Allen Butler, in his Central Park Address, May 15, 1877, on the unveiling of Halleck's statue.

${ }^{2}$ In the preface to Selections from Byron.

8 "We mark in Halleck the Byronic spirit and fire of song." American Poets and their Critics in the Knickerbocker Magazine, vol. iii, June, 1834.

4 An anonymous American (N.P. Willis?) writing on American Literature in the London Athenaum, 1835. 
quaintance with the Lyrical Ballads ${ }^{1}$ made upon him. But in his historical poem, "The Ages," he is as much influenced by Byron. "The Ages" (I82I), in thirty-five Spenserians, is Bryant's longest poem. It is a review writ large of the progress of man. The roll of the verses suggests the first two cantos of Childe Harold, as also the thought and subject matter:-

"Virtue cannot dwell with slaves, nor reign O'er those who cower to take the tyrant's yoke."

He describes where

"the abbey lay

Sheltering dark orgies it were shame to tell." 2

He sings Greece as often elsewhere $:^{8}$ -

"Yet there was that within thee which has saved

Thy glory and redeemed thy blotted name." 4

The grand in the moral world, which embraces history, has always made a strong appeal to the American mind. Of Byron's greater elements something of his historical mood seems to have made the deepest impression. But compared to Byron at his best in the fourth canto of Childe Harold, Bryant is felt to be describing history, without penetrating into its inner spirit and without reaching finality of expression.

Bryant's one other Byronic poem begins :-

"I sat beside the glowing grate, fresh heaped With Newport coal, and as the flame grew bright

The many colored flame - and played and leaped

I thought of rainbows and the northern light,

Moore's Lalla Rookh, the Treasury Report

And other brilliant matters of the sort."

1 The Philadelphia reprint came out in 1802 .

${ }^{2} \mathrm{Cf}$, Childe Harold.

3 Especially with reference to the Greek war for independence.

4 This is, moreover, one of those Byronic echoes which are so frequent in our early verse; a moment and we recall Byron's

"But there is that within me which shall tire . . . ."-Childe Harold, iv, 137. 
It has fancy, some quiet descriptions of nature, a very pale shimmer of humor, but no cleverness, no wit; and the familiarity of Don Juan was too laborious a task for the sedate Bryant. A contemporary satire ${ }^{1}$ sneers :-

"And meditations on Rhode Island Coal, Display the lofty sphere of Bryant's soul."

Bryant recalls both Byron and Wordsworth in his love of freedom; his championing of the Greek cause is Byronic in spirit, though not in manner; his reflections on freedom have less of Byron's fire, and more of Wordsworth's dignity and trust. One liberty sonnet on William Tell is a curious fusing of Byron's "Bonnivard" and Wordsworth's "England and Switzerland," both in thought, situation, rhythm and language. In general, Bryant is least Bryant where he is most Byron.

In Bryant's friend, the essayist Richard Henry Dana, Sr., the Byronic elements are very different. He is remembered as a poet for The Buccaneer, ${ }^{2}$ a pirate tale. Its supernatural terror and homely phraseology recall Coleridge and Wordsworth. But Mathew Lee, the wicked hero -

"A dark, low, brawny man was he,

His law-'It is my way';

Beneath his thickset brows a sharp light broke

From small gray eyes, his laugh a triumph spoke"-

was cousin-german of him who

$$
\text { "had a laughing devil in his sneer," } 3
$$

and brother of a dark band of tough and mysterious gentry

1 Reviewers Reviewed, see chap. iv, infra.

2 Printed with other poems in 1827.

s The Corsair, i, 9. 
who once infested the American imagination. Byronic, too, are such rhetorical questions as,

"Whose corpse at morn lies swinging on the sedge?"-

with the monitory information :-

"There's blood and hair, Matt, on thy axe's edge."

Still more obviously Byronic are some Spenserians on "Daybreak," in the mood of Childe Harold, iii, without its mysticism. He is one, he says self-consciously, who would prefer to grieve alone, one

"whom nature taught to sit with her

On her proud mountains, by her rolling sea -

Who, when the winds are up, with mighty stir

Of woods and waters, feel the quickening spur

To my strong spirit."

There is "world-pain" and New England puritanism in the following : -

"But wrong, and hate and love and grief and mirth

Will quicken soon, and hard, hot toil and strife, With headlong purpose, shake the sleeping earth

With discord strange, and all that man calls life.

With thousand scattered beauties nature's rife,

And airs and woods, and streams breathe harmonies;

Man weds not these, but taketh art to wife;

Nor binds his heart with soft and kindly ties:-

He feverish, blinded lives, and feverish, sated, dies." 1

${ }^{1}$ An aged author and friend, Thomas T. Stone, D.D. (1800-1895), in recalling Byron's early vogue, once told me of a conversation with Dana and a mutual friend just after Byron's death. As the friend ventured to question Byron's poetical gift, Dana exclaimed - "What -

'From peak to peak the rattling crags among

Leaps the live thunder!'-

the man who could do that no poet!" 
John G. C. Brainard (I796-I828) is remembered chiefly by Whittier's appreciative essay. ${ }^{1}$ His small volume (I825) contains much that is Byronic. He was fond of the Spenserian stanza. Spenserians had been written in America before Childe Harold, but manifestly in imitation of the technique and thought of I8th century Spenserians, especially of Beattie's. " In such as the following from "Jerusalem " it is no longer Beattie's, it is the stanza in the service of eloquence and history; at least that was the author's intent :-

"Lost Salem of the Jews - great sepulchre

Of all profane and of all holy things -

Where Jew and Turk and Gentile yet concur

To make thee what thou art! thy history brings

That's mixed of joy and woe - the whole earth rings

With the sad truth which He has prophesied,

Who would have sheltered with His holy wings

Thee and thy children. You His power defied;

You scourged Him while He lived, and mocked Him as He died."

There is the Byronic reflection on tyrants in "The Death of Alexander of Russia," concluding with a reference to Byron's favorite hero, Washington :-

\section{"But where is he}

Who, pure in life, majestic in his fall,

Lay down beneath his native cedar tree?

Potomac's wave, Mount Vernon's grassy pall,

That wraps his relics round, $\mathrm{O} !$ thou art worth them all."

He also imitated Don Juan in "New Year's Verses for 1825." Here, as in much American Don Juan verse, it is rather the manner than the spirit which is reproduced. They begin :-

\footnotetext{
1 Prefixed to the posthumous edition of Brainard's poems, 1832.

${ }^{2}$ As in Dwight's Greenfield Hill.
} 
"I love the Universal Yankee Nation

Where'er they are - whate'er they are about, Whatever be their wealth, or rank, or station, Their character or conduct. They are out Upon parole, or suff'rance, or probation, On horseback, or on foot - and soon no doubt, In coaches, or in Congress!-bless the land, It is a thing I cannot understand."

This suggests Greenville Mellen's Our Chronicle of 1826. Mellen shortens the ottava rima, and adopts a concluding Alexandrine from the Spenserian stanza. He proposes, he says, to be

"Sometimes sad and sometimes sad-satirical."

And he proceeds to descant on the vanity of human wishes and the different activities of men, as war, commerce, the Church, the law, and poetry. As to glory,

"Some seek it, too, in writing poetry -

Not half so good as this - and Heaven forgive

If they or anyone should think that I

Expected on such fame as this to live-

But so it is - if we can win Parnassus

We crown ourselves forthwith, to let reviewers lash us."

This whimsical complacency with one's self seems to have been one of the most frequently imitated elements of $D$ on Juan. It was doubly alluring to the self-consciousness of our amateurs in verse, and every amateur, in verse at least, is self-conscious. Mellen's Martyr's Triumph and Other Poems, ${ }^{2}$ with motto from Manfred, are Byronic. The Martyr's Triumph, Spenserians covering fourteen pages, is a story of a Christian done to death, told with Byronic eloquence and unbyronic orthodoxy. His heroics

${ }^{1}$ Boston, 1827.

${ }^{2}$ Boston, 1833. 
on "The Light of Letters" have a passage to Greece and on Byron, beginning :-

"And he who died for Greece! what tongue can tell How mourned the muses when their Byron fell?"

And his ode on Byron,

"' $\mathrm{T}$ is done, the pilgrimage is o'er,

And Harold sinks to rest;"

is that of an ardent admirer.

Such odes meet us by hundreds in old books, but presumably the best and most elaborate thing called forth by Byron's death was George Lunt's Grave of Byron. ${ }^{1}$ It is a restatement of Byron's own feelings and philosophy on man, nature, suftering and death as they appear in Childe Harold, and in the manner of Childe Harold, with here and there some good stanzas; for Lunt was genuinely inspired by pity and affection for the man, and admiration for what was best in his life and works. ${ }^{2}$ But some stanzas, such as those to ocean, become mere imitations. Byron's apostrophe was a favorite theme with paraphrasers. ${ }^{8}$

Another once popular tribute to Byron's memory was John Neal's turgid, but often musical, "The Sleeper." 4 Neal (I793-I876), one of the most amusing of our early breeders of home-culture, was a sort of rough and ready " moral Byron." In his incoherent novel Randolph(I823), one Edward Morton, an American, is represented as writing a series of letters to his friend George Stafford, an

1 Boston, 1826.

${ }^{2}$ In a note he says, "I have no intention either in the text or anywhere else of entering into a regular and unqualified defense of Lord Byron's character or writings harshly, if not unfairly."

3 See, inter alia, Lunt's "Hampton Beach" in Poems (N.Y., 1839), and "To the Sea," by W. G. Simms, in Areytos (Charleston, 1860); they contain downright copying.

${ }^{4}$ Reprinted in Kettel, vol. iii, with long selections from Lunt's Grave and from contemporary Byronides, like Carlos Wilcox (also a follower of Cowper), and others for whom there is space neither in text nor notes. 
Englishman, on American life, politics and literature; and of Neal he is made to say (Neal having one eye on Byron, the other on himself): "Talents ... . various .... contradictory . . . capricious." His "own fires . . . . may consume him to ashes" . . . and " his whole life has been a tissue of wild and beautiful adventures." Neal has similar remarks on himself in "American Writers." 1 In this same novel Morton, as a lad " unaided and alone," as a man "proud as Lucifer," who in his mighty sufferings passed in society for a mystery and a bold, bad man, "dangerous to know," ${ }^{2}$ is drawn rather more after Byron himself than after any one of his heroes. Thoughts and phrases, though here in prose, often recall familiar lines. ${ }^{3}$ It is strewn with off-hand judgments on authors, notably on Byron, of whom he asserts, "the measure and manner is worn out." 4 Far from it. For the model of Neal's tragedy Otho, ${ }^{5}$ whose hero was

$$
\text { "sternly desolate, }
$$

The monarch wanderer of the foaming deep, Companion to the spirit of the storm, So inaccessible - and so sublime,"

we have but to read a few lines in Manfred. ${ }^{6}$

1 A series of articles in Blackwood's for 1824.

2 The words Lady Caroline Lamb wrote in her diary after first meeting Byron. The phrases above are Neal's.

${ }^{3} C f$. "O woman what art thou made of ? so beautiful, yet so deadly" with

"Alas, the love of woman, it is known

To be a lovely and a fearful thing;"

and "Did you never laugh to keep yourself from crying ?" with

"If I laugh at any mortal thing

'T is that I may not weep."

"He says the same of Scott. For other criticisms on Byron in Randolph, cf. "Don Juan is only a parody upon Childe Harold by the author himself." Its licentiousness is made too much of - "Let Don Juan alone and it will be forgotten in another twelfth month" .... "His Cain, Manfred and "Ode on Napoleon' will outlive anything he has written" ... "Byron's imagination is neither brilliant nor delicate, but strong as death."

3 "Otho was a tragedy written for Cooper in the day of his strength, but never played. It was rather too melodramatic."-John Neal, Wandering Recollections, Boston, 1869. On page 194, is his own account of his once famous review of Byron's poems.

- The New England Galaxy, Jan. 14,1820, reviews "The deep terrible agonies and the deep sullen emotions of Otho" in the same terms as were current in praising The Corsair, Lara or Manfred. 
Thus, Neal admired and affected Byron's personality and his heroes, and was ready with judgments on his poetry, as on all else under heaven. But he was too goodnatured, too shrewd a Yankee, in spite of his blatant egotism and "wild beautiful adventures," to take either with absolute seriousness. Byron's style, however, in its vigor and spontaneity, he cultivated with all zeal. He sometimes has genuine force and rapidity; take the lines :-

"'T is a helmeted band! from the hills they descend Like the monarchs of storm, when the forest trees bend.

No scimitars swing as they gallop along:

No clattering hoof falls sudden and strong:

No trumpet is filled, and no bugle is blown:

No banners abroad on the wind are thrown ....

But they speed like coursers whose hoofs are shod With a silent shoe from the loosen'd sod ....

Away they have gone!-and their path is all red Hedged in by two lines of the dying and dead".... 1

The whole passage, too long to quote, has, also, a concrete reality, a vividness, not unworthy of Byron; it is one of the few instances of good Byronic poetry, as contrasted with self-conscious imitation. However, his Byronic style was oftener burlesque exaggeration. Something he names "The Conquest of Peru," made up of disjointed phrases, set off by long dashes (always Neal's and Byron's favorite punctuation), is a series of whoops and yawps, which look on the printed page like lines of racing porpoises at sea, or horses on a steeple chase.

Of a different sort was the Byronism of James Gates

1 The Battle of Niagara and Other Poems, 1818. There is in the volume something of Scott; and in the preface to the second edition (Baltimore, 1819) he acknowledged his debt especially to Byron, Moore and Leigh Hunt, of whom the last, he said, "has a nicer perception of propriety in terms, a richer and more captivating simplicity in applying epithets than any man that ever breathed." 
Percival $^{1}$ ( $1795-1856$ ), who combined celibacy with poetry, surgery, geology, chemistry, etymology ${ }^{2}$ and misanthropy. Contemporary notices place him high, naming him with Byron for his poetry, temperament, and solitary and not uninteresting personality. ${ }^{8}$ Lowell, who did for Percival's fame $e^{4}$ somewhat the same service that Macaulay did for Robert Montgomery's, found in him early in life " a taint of Byronism which indeed does not wholly disappear to the last;" whereas, the influence of Moore led to "cloying sentimentalism." The Byron in Percival was primarily the Byron of proud sorrow. Prometheus, "so like Byron at his ordinary level that it is hard to tell it apart," begins : -

"They talk of love and pleasure, - but ' $t$ is all A tale of falsehood. Life is made of gloom, The fairest scenes are clad in ruin's pall, The loveliest pathway leads but to the tomb; Alas! destruction is man's only doom. We rise and sigh our little lives away, A moment blushes beauty's vernal bloom, A moment brightens manhood's summer ray, Then all is rapt in cold and comfortless decay."

1 Life and Letters, by Julius $\mathrm{H}$. Ward, 1866.

${ }^{2}$ He spent four years correcting the proofs of Webster's Dictionary.

'See Neal's Randolph: "Mr. Percival . . . . addicted grossly to Byron "; and Knapp's Sketches of Public Characters (1830): "His Prometheus is full of deep philosophy and fine poetry "... " His smaller pieces are in every magazine and newspaper in the country" ...." His elements are all poetical."

The London Athenceum for 1835, in articles on American Literature, which were possibly written by Willis, says: "The first poet of America by the rule of Horace, poeta nascitur non fit, is James G. Percival," p. 64 ... . "Percival looks the poet more absolutely than any man we ever saw ; it is written on his forehead, and steeped in his eye, and wound about his lips ... . Percival is the most interesting man in America," p. 65.

Goodrich observed in his Recollections: "He walked the world like one who neither accepted nor desired its friendship . . . . out of tune with the great harmony of life around him .... I think he had been deeply injured - nay ruined by the reading of Byron's works," vol. ii, p. 131.

See also prefatory notes in Kettel and in the British collection of American verse entitled The Columbian Lyre. Kettel compares him to "the sad and despairing prophet of the British Lyre."

${ }^{4}$ In the review of Ward's Life and Letters, 1867.

$5 \mathrm{Neal}$, in Randolph. 
He was an adept in the pose of pride and of lonely contemplation of himself as a suffering genius. "A Fragment" contains such servilely Manfredian verse as :-

"It is the noon of night, the stars look faint

With their lone watching ....

I have thus often sat and deep in thought

Outwatched the stars....

.... I have gained

Much doubt and little certainty

But I have gained a mastery over spirits."

He could imitate also the sublime in Byron, both of nature and of history; while the decay of Greece and her new struggle for liberty were subjects of many lyrics and blank verse musings. What was most Byronic in Percival seems just what made him most popular - an indirect proof of Byron's own popularity. For the rest, a detailed study of all Byronic imitations and pilferings of Percival would require a separate volume. ${ }^{1}$

The one American, however, now most popularly associated with Byron, is Poe. This rests chiefly on the notes of gloom and "nevermore" in his poetry, on his unhappy life and romantic appearance, ${ }^{2}$ on his pride, ${ }^{3}$ and on his feats as a swimmer. Only in his earlier work does he owe anything to Byron. Tamerlane is "as clever and uninteresting an imitation of Byron as was ever printed," says his biographer. ${ }^{4}$ It has the gloom, pride and guilt of the tales, but less of their force, clearness and directness,

1 In the Poetical Works (1859) Shelley is the guiding spirit.

2 Poe, in earlier years, says Hewitt, quoted by Woodberry, "wore Byron collars and a black stock, and looked the poet all over."

3 "Byron had sown the evil seed [of pride], but it had fallen on very favorable soil." Woodberry.

${ }^{4}$ Professor Woodberry, in American Men of Letters Series. 
for even here one finds Poe's mystic vein which is unbyronic and not adapted to narrative. "The Coliseum," in blank verse, in subject, situation, thought and eloquence, is very Byronic: a prize poem, it followed the mode.

In the same year with Poe's first volume, William Gilmore Simms published two "daringly Byronic" volumes of lyrical verse, and in I830 "The Tricolor," "a Byronic outpouring in honor of the Three Days of July." Choruses of Atlantis ( $183^{2}$ ) were inspired by lyrical passages in Manfred. Imitations like the following are rare; a Zephyr-spirit sings :-

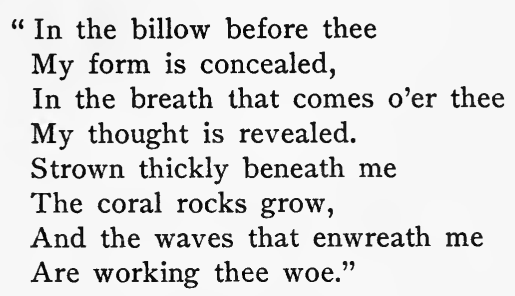

But Byronic in the usual way is Donna Florida, " a Tale," written also in youth, left unfinished and published in 1843 with an apologetic preface. "He fancied," he there writes, " with boyish presumption that he might imitate the grace and exceeding felicity of expression in that unhappy performance [viz. Don Juan] -its playfulness and possibly its wit - without falling into its licentiousness of utterance and malignity of mood." Such was the aim of most of our imitators, though they were not so generally desirous of "forbearing personal sarcasm and domestic satire," as the ever-hearty and leonine Simms. Moreover, Simms as

${ }^{1}$ W. P. Trent, William Gilmore Simms in American Men of Letters Series, p. 58 ; see also p. 7 : "In all probability Byron and Scott and Moore had nowhere a more devoted admirer than this little Charleston boy." 
a novelist was interested in the story he had to tell, and did " not suffer his digressions to be so numerous or so long as those of the work which he unwisely made his model." This will enable the reader to judge of Donna Florida. 


\section{CHAPTER IV.}

\section{BYRON'S LITERARY INFLUENCE, I830-I860.}

SIMMS, John Neal, and indeed most of the writers men$S$ tioned in the last chapter lived on to do better work in the period following, but, with the exception of George Lunt, they grew away from Byron. Some, notably Poe, lived on to strike altogether original notes; others, like Neal and Percival, came under the influence of Shelley or of poets contemporary with their own maturity. Byron himself was now some years dead, and the romance attaching to his person and adventures had become with the older generation a too familiar tale. Byronism, between 1830 and 1860 , is to be traced in writers relatively of less importance to the literature of their time.

- Samuel Griswold Goodrich, to whose Recollections ${ }^{1}$ we were indebted in the second chapter, himself wrote Byronic verse. The Outcast ${ }^{2}$ is made to confess how

"One crime hath twined with serpent coil Around my heart its fatal fold;"

and to recall his boyhood with nature by the sea, as Byron had done once and again. But at times,

\footnotetext{
${ }^{1}$ In the Recollections he speaks of Byron's effect upon him. "There was in me certainly none of the misanthropic feeling which made Byron fall in love with such scenes. Nevertheless, some passages in Childe Harold which appeared a few years after, described the emotions I then experienced." . . . " I had no feeling of unhappiness, no oppressive sense of isolation, no anxiety, no ennui." Vol. i, p. 154.
}

2 The Outcast and Other Poems, Boston, 1836. 
"Such the madness of my brain

That I was fain to seek the throng,

To meet and mingle in the main [?]

With their mad revelry and song."

and soon we have it :-

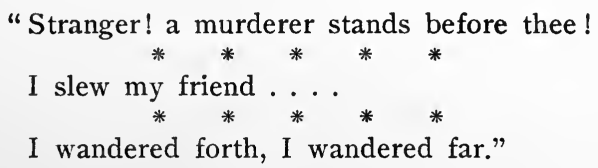

But at last :-

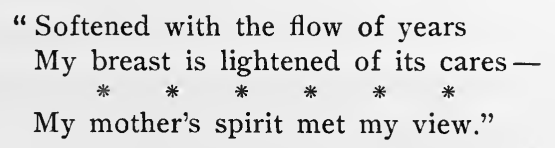

A touch of piety, resignation and mother-love ${ }^{1}$ were devices, artistic or otherwise, frequently introduced to chasten and subdue Byronic tales of gore and gloom for American readers.

Yet the most complete imitation of the Tales, not excepting Tamerlane, seems to have been the Melanie ${ }^{2}$ of Nathaniel Parker Willis. Willis, so "natty and jaunty and gay," as purveyor of the Byronic dark and terrible in love and crime, shows how very artificial Byronism might become, even among well-known writers. Melanie has the movement of Chillon, and attempts to create the Italian atmosphere of Parisina, as in :-

\footnotetext{
1 Note the part mother-love plays in American sentimental literature, as in the Civil IVar songs and modern melodrama.

${ }^{2}$ London, 1835. Willis was at this time travelling in Europe. His Pencillings appeared in the same year.
} 
"It was an endless joy to me

To see my sister's new delight

From Venice in its golden sea

To Paestum in its purple light -

By sweet Val d'Arno's tinted hills" .... 1

But when Angelo, Melanie's betrothed, is revealed as a bastard, the horror of her brother, who tells the tale, becomes more violently Byronic :-

"My heart was locked! The lips might stir, The frame might agonize - and yet

O God! I could not pray for her!

A seal upon my brow was set,

My brow was hot - my brain oppressed," - etc.

Finally Angelo's identity is more completely discovered before the marriage altar by a nun who shrieks through a lattice :-

"The bridegroom is thy blood - thy brother, Rodolph de Brevern wronged his mother!"

The nun is thus the mother of all three! The bride sank down dead, but the narrator stoically

$$
\text { "shed no tears for her," }
$$

realizing that

$$
\text { "she died }
$$

With her last sunshine in her eyes."

At this denouement one hardly knows whether one is more reminded of Byron - or of the bizarre groups in red,

${ }_{1}^{1}$ There are sometimes echoes of Scott's phrase and manner, as : -

"And sometimes at St. Mona's shrine,

Worn thin with penance harsh and long."

The very first line :-

\footnotetext{
in "The Isles of Greece." "A king sate on the rocky brow,"

"I stood on yonder rocky brow," is obviously after Byron's : -
} 
yéllow and blue on the bill-boards advertising a modern melodrama.

In his Lady Jane ${ }^{1}$ Willis was able at once to imitate and to maintain something of himself. It is in part a social and literary satire, with more temperamental lightness and gayety, more unity of story ${ }^{2}$ and mood in its two cantos of ottava rima than Don Juan and most American imitations. But there is an attempt to intersperse the higher poetry, there are digressions ${ }^{8}$ with self-conscious apologies, comments on contemporaries, and a familiar address to the reader in conclusion. Byronic, too, are the clever rhymes, as :-

"I am an old maid, and tho' I suffer by it I

Must change my style and leave off gay society"-

or : -

"Dinner! ye gods! what is there more respectable;

For eating, who, save Byron, ever checked a belle?"

The situation of Lady Jane and Jules, the boy poet, is after that of Julia and Juan :-

"The Lady Jane still thought him but a lad, Then why the deuce she didn't treat him so Is quite enough to drive conjecture mad."

Willis' mild desire to be racy -

"I say, that up to kissing - later even

A woman's love may have its feet in heaven"-

is as laughable ${ }^{4}$ as his early reputation for a rake and lady-killer among relatives and friends who went to church

1 New York, 1844.

2 The sub-title is "A Humorous Novel in Rhyme."

${ }^{3}$ Byron, his wife and La Guiccioli are the subjects of Canto ii,10-11. In imitations of Don Juan, references to Byron are the rule without exception.

4 See the Satire, The Paradise of Fools, next chapter. 
at Brimstone Corner. The morality of our literature has always been the chief boast of our critics. ${ }^{1}$

References to or descriptions of Greek, Italian and Oriental ruins elsewhere in Willis' poetry, also suggest Byron, who had more than anyone aroused the world's interest in the picturesqueness and the pathos of the classic past. In this respect Willis' verses are paralleled by the steel engravings of the Annuals, ${ }^{2}$ to which he often furnished the text.

The most many-sided imitation of Don Juan as of Childe Harold was written by George Lunt. It is five cantos of ottava rima, entitled Julia. ${ }^{3}$ In general management of rhymes and digressions, in attitude of confidential familiarity with the reader, in interspersion of higher poetry and of lyrics it is rather, facile; but in ideas and tone its satire is very mild (frivolity and dancing in Boston receiving, perhaps, the most scathing rebuke), and without wit. The poetry has an occasional dreary note, lamenting

"The few - down the dull blank waste of years;"

and Julia is described on the beach of Nahant, Boston's popular summer resort, ${ }^{4}$ as one who sadly,

"gazed .... ever on the dark blue sea;"

\footnotetext{
11 know of but one imitation of Don Juan which rivals the naughtiness of the true one, and the only accessible copy is locked up in a drawer of the Harris Collection at Providence. It is entitled Susie Knight, and appeared in the New York Clipper in 1863.

2 In pictorial art Turner illustrates a great inspiration drawn from Byron as opposed to the implicit imitations of the Annual Engravers. Cf. Especially "Childe Harold's Pilgrimage" in the National Gallery. The paintings of Cole and Church in America betray a slight inspiration. Their historical romantic mood owes something to Childe Harold.

${ }^{3}$ Boston, 1855, with pseudonym Wesley Brooks. The name "Julia" is itself Don Juan-ny.

4 The importation of Byronic heroes, heroines, moods and situations, to well known spots in the United States, was one of the minor phases of Byronism, and of the effort to found a national literature on English lines.
} 
and there is a rather harmless tendency to a sensuous description of Julia sleeping, when

"The folded linen on her whiter breast

Rose with its gentle swell."

Two passages are taken almost directly from Don Juan. ${ }^{1}$ Miss Julia's coming out, the ball and supper, may have been suggested by Fanny. The plot, a girl's true love for a poor suitor against her father's harsh and natural preference for a rich one, is a grafting of the universal bourgeoise pathetic on Byronism, while the stanzas on the childhood home and on the ill-fated poor suitor's final return to his mother's arms, illustrates the grafting of the specially American bourgeoise pathetic. In an earlier volume Lunt had been lyrically Byronic. ${ }^{2}$

The Cabiro ${ }^{3}$ of the versatile, long-lived critic, translator and poet, George Henry Calvert, is another once read American Don Juan, combining tale and satire. The former is insignificant. He says, beginning with an echo:-

"Choose well your hero and he'll make a tale,"

but confesses shortly, affecting the Byronic negligence :-

He rather

"I will build no story, have no plot."

"freely paints
Together, apes, clowns, mountebanks and writers."

His remarks on

$$
\text { "this gay Italian verse" }
$$

"One is the famous "'T is sweet," etc.

2 Poems, New York, 1839; his last volume, 1884, is not Byronic, but it contains a "Hymn of Greek Youths"'at Byron's funeral - probably written much earlier.

${ }^{3}$ Cantos i-ii, Baltimore, 1840 ; iii-iv, Boston, 1864. 
are after Byron's in Beppo. ${ }^{1}$ Cabiro is more intellectual than other imitations. It contains good observations on the Germans, ${ }^{2}$ on Coleridge, Wordsworth and Byron himself, on man in general, and on marriage, money and dinner.

Other elements in Byron appealed to Bayard Taylor. Apart from his Juvenalia ${ }^{3}$ and a few echoes of lyrics in Byron's dramas, ${ }^{4}$ Taylor recalls Byron most in his Poems of the Orient (1854), of which “Amram's Wooing," differing from Byron, however, in its happy ending, runs some of the lines in The Giaour and the Bride of Abydos pretty closely. For a bit of description in Byron's earlier vein, not unlike things in the Siege of Corinth, read:-

"The yellow moon was rising large

Above the desert's dusky marge,

And save the jackal's whining moan,

Or distant camel's gurgling groan,

And the lamenting monotone

Of winds that breath their vain desire,

And on the lonely sands expire,

A silent charm, a breathless spell,

Waited with me beside the well."

For passion, as strong as Selim's, read :-

"Trembling and panting and oppressed

She threw herself upon my breast,

By Allah! like a bath of flame,

The seething blood tumultuous came

From life's hot centres as I drew

Her mouth to mine, our spirits grew

Together in one long, long kiss -

One swooning, speechless pulse of bliss."

1 Stanza 44.

${ }^{2}$ Calvert was one of our earlier German scholars. His translation of Don Carlos appeared in 1836.

${ }^{3}$ Ximena, or The Battle of the Sierra Morena and Other Poems (1844). "To the faint lyrical faculty that he already displayed is superadded a very evident affection for the manner of Scott and Byron and Muore and Mrs. Hemans."-Albert H. Smith, Bayard Taylor, p. 33, in American Men of Letters Series. These poems were fifteen in number, and none have been included in later works.

- The lyrics of Deucalion seem to have been influenced by those of Manfred. 
Amram's steed

"Of Araby's most precious breed"

is described quite as if twin brother to Mazeppa's. Four of Byron's tales contributed to this short piece, yet living emotion and steady imagination made it something of Taylor's own and a fair poem.

Albert Pike's poems ${ }^{1}$ are dominated by Byron. ${ }^{2}$ Besides Spenserians on nature and on

"A soothing melancholy hope inclined,"

and such questionings as

"What is there left that I should cling to life?"

where his sorrow (which was, we know, sincere) was more pensive than Byron's, his lyrics are especially to be noted :-

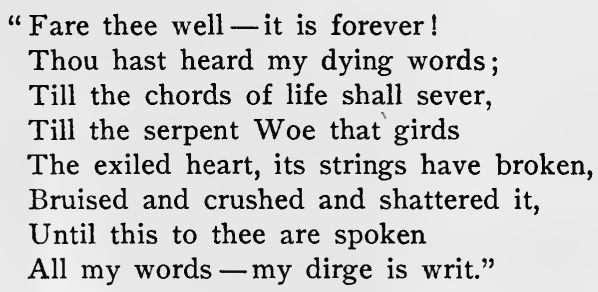

His "Song of the Nabajo" is a direct paraphrase of "Tambourgi" : -

"The Moqui may boast from his town of the Rock:

Can it stand when the earthquake shall come with its shock?

The Suni may laugh in his desert so dry -

$\mathrm{He}$ will wail to his God when our foray is nigh.

$\mathrm{O}$ who is so brave as a mountain Apache?

He can come to our homes when the doors we unlatch,

And plunder our women"-etc.

1 Prose Sketches and Poems, Boston, 1834.

2 But Keats' influence is also strong.

3 Childe Harold, i, 72. 
The substitution of Indian for the Oriental names of Byron's poetry was only more common than the similar substitution for the Scottish names of Scott's. We shall see later how Byron's heroes reappear in paint and feathers.

Charles Fenno Hoffman, ${ }^{1}$ now remembered only for " Monterey," published thirty-three amorous lyrics, "Eros and Anteros," "2 even more Byronic, if possible, than Pike's, in this vein :-

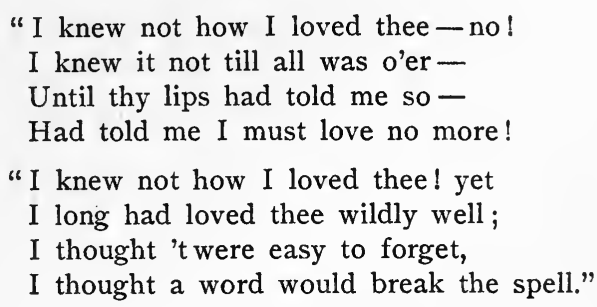

George H. Boker is called in a contemporary satire ${ }^{8}$ "Byron Boker," certainly not for his dramas, which, like most literary dramas of those days were modelled on Sheridan Knowles, but presumably for his personal appearance, or for lyrics such as "Vestigia Retrorsum" : -

"There is a spot I call accursed Because my thoughts forever wing Back to its gloom from which they burst And settle on the loathsome thing."

Willis Gaylord Clark ${ }^{5}$ wrote gloomy Spenserians, as : -

"Man sinks down to death, chilled by the touch of time," etc.,

1 The Vigil of Faith and Other Poems, N.Y., 1845. The Vigil, like The Lays of the Hudson, 1846, is an Indian tale more in the manner of Scott than of Byron.

${ }^{2}$ In view of the character of the pieces, it is natural to guess that this title itself may have come from Byron. Cf. Manfred, ii, sc. ii : "Eros and Anteros at Gadars." Imitators of Byron often conned his pages for poetic titles as well as for learned foot-notes.

3 Parnassus in Pillory, see next chapter.

4 Plays and Poems, 2 vols., Boston, 1856.

' Poems, 1839 (?) Literary Remains, 1844. 
and a lyric "Euthanasia" in the melancholy stanza form of "And thou art dead," a once popular model.

It need hardly be added that most melancholy lyrics of minor poets, whether on lost love or lost hope or what not, were dominantly Byronic, when not pensive, homely, moralizing after Mrs. Hemans, or, indeed, after Longfellow. Sometimes, as in the poems of Sarah Helen Whitman relating to Poe, the poignant reality of sorrow lends a genuine voice even where the situation or theme is Byronic. ${ }^{2}$

The gloom in Richard Henry Stoddard's poetry has more than once led to comparisons with Byron. His Songs of Summer (1856), containing lines like :-

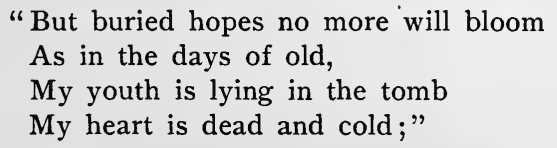

even the unrelieved pessimism of The King's Bell (1862) ${ }^{3}$ and the dreary "Rome" 4 are in a plaintive elegiac minor key of resignation, very different from the Byronic sufferance and revolt. Moreover, neither verse forms nor images suggest Byron, and Stoddard is much more consciously artistic.

Amusing and sad at once it is to turn to the gloomy juvenile verses (1855) of William Winter. Stoddard spoke as a man out of his own heart's life, of a "world-sorrow" he could express with his own voice; Winter, as a boy, self-consciously imitating another's sorrow and another's voice. Juvenile Byronism of a kind was never more com-

1 "Euthanasia" is the name of the poem preceding this in the so-called "Thyrsa Elegies," and Clark evidently borrowed it.

${ }^{2}$ Poems, Boston, 1879. In several pieces she echoes intentionally Poe's own voice, as if she heard it still.

${ }^{3}$ It shows the influence of Longfellow in the language and versification.

In The Book of the East. 
pletely recorded than in this little volume of one hundred and eighty-nine pages, wherein we read:-

"Childhood is fettered, even the laughing boy

Languid and satiate with continual joy"....

"Pride wastes affection - what is Wisdom's state?

The soul is void - the heart is desolate."

This is mentioned here not without reason, for the time was drawing nigh when Byron in America was to influence only boys; indeed, to parallel to-day the imitations chronicled in this book, one would have to rifle the desks of one's young literary friends, who are yet already wise enough to keep their own very early works unpublished and locked up. ${ }^{1}$

Before the sixties, Browning and Tennyson had begun to succeed Byron, though never popular to the same degree. Timrod's fine work was Tennysonian; Stedman's earlier poems in stanza and diction and flavor even more so $;^{2}$ and Stoddard adopted the In Memoriam language and stanza. ${ }^{8}$ W. W. Story, whose earlier work was after Tennyson, becomes later in psychological analysis, ${ }^{4}$ in matter, even in the titles he gives his poems, ${ }^{5}$ and in the visualized and ingenious similes without emotional relation to the

1 One confessed to me having written a canto to Don Juan only six years ago.

2 Poems, Lyrical and Idyllic, 1860. "Flood Tide" is "Locksley Hall," even to metre and type of simile. For the latter, $c f$.

"Cold and shining sea of ages ! like a silver fillet set,

On the earth's eternal forehead, for her bridal coronet"

with Tennyson's Pleiades, like " fire-flies tangled in a silver braid," and contrast both trivializations of the Cosmos with the great simple siniles of Wordsworth and Whitman.

"See "A New Christmas Carol" in The Book of the East :-

$$
\begin{aligned}
& \text { "It was not thus in days of yore, } \\
& \text { In brave and merry England's prime, } \\
& \text { Our fathers kept the Christmas time } \\
& \text { The merry Yule that is no more." }
\end{aligned}
$$

"Sęe "A Roman Burger in Jerusalem."

"As "Padre Banelli proses to the Duke Ludovico Sforza about Leonardo da Vinci." 
context, ${ }^{1}$ perhaps the most Browningesque of the poets out of George Meredith and-Browning. W. R. Wallace (I8I9-I88I), who had begun with Scott and Byron, ${ }^{2}$ and ended with Tennyson, ${ }^{3}$ may be named as one of the many not altogether unworthy souls who tried both the old and the new. Tennyson's art and "divine despair" succeeded Byron's force and gloom, the In Memoriam stanza, Byron's Spenserians. ${ }^{4}$

1 Cf. "Privation, like a darkened tube,

Made joy the sweeter, thro' its darkness seen,"

in "The Confessional." Here is not the place to enlarge upon this point. Poetic influences are never more subtle and sure than in the similes employed, and there is no more interesting work for minute scientific criticism than the tracing of such influences.

2 Battle of Tippecanoe, 1857; Alban the Pirate, 1848.

3 Meditations in America, 1851 ; see, especially, verses modelled on "The Palace of Art."

4 It has been out of the question to make this and the preceding chapter absolutely complete. E. C. Pinkney's Rodolph (1825), a two-canto tale of love, and some of his lyrics; A. B. Meek's Songs and Poems of the South (4th ed., Mobile, 1857), and his Red Eagle (N.Y., 1855), a tale of the Creek Chieftain and the massacre at Fort Mimms, Ala., in 1813; "Gonello," a gay Florentine tale in Epes Sargent's Songs of the Sea and Other Poems (Boston, 1847), a la Don Juan ; R. H. Wilde's Hesperia (Boston, 1867, edited by his son), an elaborate imitation of Childe Harold; and possibly a few bits in John Pierpont's Airs of Palestine (1840) and in his vigorous lyrics, may be noted in conclusion. 
CHAPTER V.

\section{BYRON'S SUB-LITERARY INFLUENCE.}

THE general reader has probably no conception of the fecundity of American poetasters and the fatuity of American publishers. It is extraordinary, even to-day, and must undoubtedly remain one of the concomitants of democracy, until democracy succeeds in deepening as well as in widening culture. It was more extraordinary, though not so astonishing, two generations ago. When Willis' "Sketches" were great poetry to the public, and Maria Gowen Brooks's Zophiel appeared as sublime as Dante to the critic, ${ }^{1}$ when The Token, The Keepsake, The Iris, The Hyacinth, The Jezvel, The Ladies' Garland, etc., with their gold trimmings and sentimental engravings, occupied the spot on the parlor tables of the fashionable and elegant, one may expect fecundity in poetasters and fatuity in publishers. Work, such as must now detain us, can hardly be called literary, yet as the literary impulse, the literary process, was there, and the results came out in hot-pressed twelves, attractive enough in paper and typography, perhaps it can be best classified as sub-literary. However, in American verse, the boundary line is not easy to draw with certainty after passing the fields that some twenty or thirty have made finally and surely their own. In the last two chapters, it may be, there are two or three who might better have been named below; and below, it

\footnotetext{
1 To Grisnold; see his Female Poets. Zophiel, though recalling in its plot Byron's Heaven and Earth, is in style modelled on Southey and Moore.
} 
may be, are two or three who might better have been named in the last chapters.

Sub-literary Byronism may be traced in imitations of the English Bards, of the lyrics, of the tales, of Childe Harold, and of Don Juan. Byron's reading dramas, save Manfred, seem to have made little impression on either literary or sub-literary writers; his acting dramas none at all. ${ }^{1}$ It will be convenient to group our material chronologically under these heads. I will take the English Bards first, for here we have not only imitations, but frequent allusions to contemporary Byronism.

\section{The English Bards.}

In $18 \mathrm{r} 7$, Solyman Brown published his views of American verse ${ }^{2}$ in homespun heroics. They have something of the directness and miscellaneous character of the English Bards, though his satire was no servile copy like some below. His attack on

\section{"The loathsome filth of Scotch Reviewers"}

seems to have been prompted by a genuine animus against the Edinburgh Review, long shared by many Americans. Byron himself is referred to as "faithless," and his domestic troubles are discussed in the notes, while a lyric among

${ }^{1}$ Byron's effect on the American Stage seems to have been confined to his " Drury Lane Address." See, Rejected Addresses (bona fide), New York, 1821, written for the reopening of the Park Theatre, which, like Drury Lane, had been destroyed by fire. Charles Sprague was awarded the prize, but his couplets are independent of Byron's. Yet the two pieces appear to have been popularly associated. See :- "Will Byron's prize address at Drury Lane compare with Sprague's at the Park Theatre?" - Knickerbocker Magazine, June, 1834.

Werner and Sardanapalus, however, have been acted in America.

${ }^{2}$ An Essay on American Poetry and Other Poems, New Haven. It was reviewed the next year by Bryant in the North American. 
"other poems" represents Lady Byron upbraiding her Lord. "

More lively is "a satirical effusion" by J. L. Martin," which is modelled both on Pope and Byron. With the savagery of the latter he goes hand over fist in medias res:-

"And first, ye Yankee Byrons, take your part, Ye mimic Harolds, feel the well-earned smart, Ye merchant Corsairs, legal Laras ....

.... aspiring to attain

The lordly poet's dark Promethean strain."

And he asseverates that they will have to do more than affect long hair, a cloak of "gloomy fold," and a naked neck; nor even

" by wandering with a lowering brow,

Nor walking among men as in a cloud."

shall they attain it. It is

"a nauseous trick

Which can deceive some foolish girl at most,"

since

"The outward form cannot the mind avail."

His advice was timely :-

"Go plough your fields, teach hopeful youth" ...

anything mundane and practical -

"But sport not antics on the awful grave

Of him alas! whom genius could not save."

1 "Fair thee well, inconstant lover!

If thy fickle flame was love,

Tho' our transient joys are over

I can ne'er inconstant prove,"-etc.

${ }^{2}$ Native Bards, "A satirical effusion by J. L. M.," Philadelphia, 1831. 
Here follow a page of panegyric on Byron and some observations on American imitators of Moore, the only other contemporary English poet he names. To the same date belongs Truth, "A New Year's Gift for Scribblers" by Joseph Snelling, dubbed by Willis, "Smelling Joseph." It is equally rough, and somewhat Byronic.

In Reviewers Reviezed, ${ }^{1}$ many of the phrases are copied or imitated from English Bards, but the marked attempt at reasoning, the frequent triplets, enjambements and Alexandrines, suggest Dryden, who is besides mentioned prominently, rather than Byron as the model, and it need not detain us.

Probably the most notorious in its day was The 2uacks of Helicon, ${ }^{2}$ by L. A. Wilmer. It is in the form of a Popian epistle, beginning :-

\section{"Against usurpers, Olney, I declare}

A righteous, just and patriotic war,"

but the virulence of the war is Byronic. He reviles the ballads of the genial Morris and the inanity of wellgroomed Willis, while Bryant and Longfellow are handled as rudely as Byron had handled Wordsworth and Coleridge. Even Poe, who bore Longfellow no especial friendship, felt called upon to protest. $^{3}$ I quote as a specimen what he says on the drama:-

"Now poesy and taste yield up the stage

To all the trash and twaddle of the age,

To light-heeled harlots, eunuchs and buffoons,

Black-souled Biancas and black-faced Zip Coons."

This was written at a time, it will be remembered, when

${ }^{1}$ New York, 1837, by Miss A. C. Ritchie, in vengeance for uncomplimentary notices of Pelayo, a rhymed metrical romance after Southey and Scott.

2 Philadelphia, 1841. Wilmer was the author of the sensational exposure, Our Press Gang.

3 in a review of the piece, reprinted in Poe's collected works. 
American "poets" were making strenuous efforts, now long since abandoned, to produce literary stage plays in verse.

Another Philadelphia satire, The Poets and Poetry of America, followed in 1847 , under the pseudonym "Lavante." ${ }^{2}$ It is the most literal of imitations : the substitution of an American for an English name is often the only original element; Byron's "Boeotian Cottle," becomes "Boeotian Hill," "Unhappy White," “Unhappy Clark ; "

"Precocious Sargent to the drama dear,"

is from

"Coleridge ... . To timid ode and turgid stanza dear," and

is from

"Health to prejudging Saunders!"

"Health to immortal Jeffrey!"-

and so forth. The ideas, metaphors, allusions, animus are equally servile. Byron is mentioned by name as the master satirist, to whom "Lavante" naturally feels a kinship in experience and in power. He confessed:-

"I too can rhyme and in my time have sung

When hope was high and infant muse was young,"

because Byron had confessed :-

"I too can scrawl, and once upon a time

I poured along the town a flood of rhyme,

A school boy's freak;"

1 As Hillhouse, Payne, Sargent, Calvert, Matthews, Dawes, Osborne, Willis, Mrs. Ellet, and Mrs. Mowatt, the actress.

${ }^{2}$ An edition (New York, 1887), contains an introduction by "Geoffrey Quarles" to prove Poe its author. This reads like a hoax; Wilmer's name is pencilled in the copy in the Columbia University Library. 
and he closes with a universal challenge, having all the bravado of the closing paragraph of his model.

The author of Parnassus in Pillory, ${ }^{1}$ though invoking the aid of Horace and Pope, derived his real inspiration also from the angry young lord. The elegance of Pope had fitted well the quiet, accomplished colonial gentlemen, but it was less in keeping with the rough and ready bumptiousness of these times. After denouncing Lowell as

"now sententious, now most wordy,"

and Morris as

"A household poet whose domestic muse,"

Is soft as milk and sage as Mother Goose,"

and arraigning the throng who are

"Aping his strains, with throats all cracked and wheezy,"

and after sneering that

"Lunt's lead with Byron's gold was soldered,

That Wordsworth dribbles thro' meandering Stoddard, .... that Harvard grants its benison

To those alone who canonize Saint Tennyson,"

and pitching into everybody else on his

even to

$$
\text { "Pegasus the skittish" }
$$

$$
\text { "our critic friends, the British," } 2
$$

he dismounts, lays down his mace, and concludes with satisfaction,

"An honest Anglo-Saxon round of blows

I 've dealt alike upon my friends, and foes."

1 "Motley Manners" [A. J. H. Duganne], New York, 1851.

${ }^{2} \mathrm{He}$ has taken the rhyme from Don Juan, i, 209. 
His testimony on then existing conditions is interesting. He voiced with Poe, Cornelius Matthews, Bryant, Griswold, R. G. White, and others, the growing desire for international copyright. ${ }^{1}$ He was sensible of our limitations; Bryant was, he granted,

"Brobdignagian - but

Just so was Gulliver in Lilliput ;"

and he noted with patriotic disdain how

"Our country swarms with bards who've crossed the water

And think their native land earth's meanest quarter,"

and who

"Muse, just like Byron, on the Bridge of Sighs." 2

The last to be mentioned bears the modest title of Parnassus in Philadelphia. ${ }^{3}$ Disgusted with contemporary letters, the author admits :-

"Once I was fool enough to spin like these My idle rhymes, in hopes like them to please, A youthful freak, tho' older heads have oft By time grown mellowed, proved themselves as soft."

And again, as Byron had referred back to the time when

"a Pope's pure strain

Sought the rapt ear to charm nor sought in vain,"

so he to that

"When Scott and Byron with a thousand more Chaunted their hallowed strains from

Albia's [sic] shore."

1 See, inter alia, Speech on International Copyright, delivered at the dinner to Charles Dickens, N.Y.. Feb. 19, 1842, and the Appeal on Behalf of International Copyright, N.Y., 1842, by Matthews; Address to the People of the United States on Behalf of the American Copyright Club, N.Y., 1843, by Bryant ; and The American View of the Copyright Question, by White, in the Broadway Magazine for May, 1868.

2 As H. T. Tuckerman (Poems, Boston, 1851) who wrote some blank verse on Lord Byron at Venice, or E. D. Griffin with his "Lines on Leaving Italy," historic and Spenserian (see Griswold's Poets), or George Hill, the dyspeptic consul for Asia Minor, whose verses on "The Ruins of Athens" bemoaned man's

"weary spirit that forsaken plods

The world's wide wilderness."

${ }^{3}$ By Peter Pindar, Jr., [H. S. Ellenwood], Phil., 1854. 
He has a "goose-quill," like Byron's, " eager for the war;" he judges, like Byron, the critical merits of Jeffrey and Gifford; and becomes very personal in discussing his countrymen :-

"Go, Byron-headed Boker, mend thy verse,

But stick to blank - tho' poor, thy rhyme is worse;"

J. J. Woodward,

and

"Seeks to rival fame and Walter Scott,"

while

"dark revengeful is his hollow tone,"

"Deep passion, too, for amorous maids he deals [sic-feels?]

And what he lacks himself, from others steals -

Scott, Moore and Byron;"

but of Morris :-

"Simple thy strain, and sweet thy little song

Wakes no resentment as it flows along."

He subjoins copious footnotes, imitating the dash and hit or miss of his lordship's, with quotations from Horace and Pope and Italian proverbs, all of which he undoubtedly filched (a common trick) from his own well-thumbed edition of Byron.

Pathetic and portentous is this in conclusion:-

"Hark! from New England's peaceful shores arise Ten thousand lyres, whose music sweeps the skies While, like the echo from Apollo's strain, The South wafts back a kindred song again!

But thou, O Philadelphia! Poesy,

Tho' living yet, is almost dead to thee."

It is to the ten thousand lyres and the kindred song that we must now turn. ${ }^{1}$

${ }^{1}$ Of the many literary satires of those days only the Fable for Critics has survived, and it is a genre by itself. 
II. The Lyrics.

In the imitations of Byron's lyrics we are especially reminded of Byronism in the early newspapers, and as has already been said were reprinted from magazines and annuals. ${ }^{1}$ Byronic lyrics were naturally a most prevalent form of Byronism. There are those still living who can recall the time when it was almost as fashionable and fitting for refined ladies and gentlemen to dash off a Byronic stanza or two, as it was

\section{"In gallant days of ruffed Elizabeth"}

to write sonnets, or in prim Queen Anne's to turn an epigram. Beside much prevailingly amorous, skeptical or gloomy, there was much after Byron's Greek poetry and the Hebrew Melodies.

The verse about Byron has been already touched on, but the temptation can not be resisted to revert to it here. Rev. J. W. Curtis, M.A., ${ }^{2}$ deemed

"The muse of pure Watts the finest of gold,"

and said of Byron, he left

" a poet's name to other times

Linked with one virtue and a thousand crimes, Oh! never may our country mourn the fate Of native bard like him."

The one virtue appears from another lyric to have been his death for Greece. Rev. J. W. Curtis has also lines on Greek liberty, and he ranked himself with Brooks, Percival and Byron as a philhellenic bard.

${ }^{1}$ Some were even reprinted from the newspapers, as the verses of " the Boston Bard."

${ }^{2}$ Poems, N.Y., 1846. 
Byron's separation from his wife, his quarrels, the refusal of the dignitaries of Westminister Abbey to admit his body to burial, were also favorite themes. On the last the popular feeling, popularly expressed, was :-

"When Freedom and Genius in triumph return

To rebuild their old temples and visit the new, The first shall an altar erect to his urn,

And the strains of the second shall hallow it too." 1

Further citations would belong rather in some unwritten book on American humor.

The most interesting and tragic of all followers of Byron in his wild life and wilder lyrics of despair, bravado and aspiration, was McDonald Clarke, "the mad poet," as he was called and called himself. The bitterest experiences of life overthrew his sensitive, craving nature, ${ }^{2}$ and gave his numerous erratic volumes sometimes a reality, a pathos, which not even their extreme chaos, crudity and imitative style can destroy. He showed, too, brief flashes of genius, striking off occasional metaphors of surprising originality and power, ${ }^{3}$ and some tender stanzas of poignant simplicity. ${ }^{4}$ By misfortune and temperament he was drawn to Byron. "When Byron was in the hey-day of

${ }^{1} C f$. "The Greeks will erect a monument to his memory out of the ruins of the tombs of Pindar and Alcibiades; and when time has sunk some glaring instances of his profligacy into dimness and shade, the mitred guardians of Westminster Abbey may permit a slab to be sculptured with his name." - Advice on the Pursuits of Literature, by S. L. Knapp (?).

2 See the heart-rending preface to his Elixir of Moonshine, N.Y., 1822.

${ }^{3}$ See "Memorial of M'Donald Clarke" in Book Notes, Feb. 2, 1884.

"Freedom in shirtless majesty,"

and the well-known "Now twilight lets her curtain down
And pins it with a star"

are his,

${ }^{4}$ As

"O man must have a home, a home, It matters not how poor it be." -

He had none and Halleck made him the subject of his poem, " The Discarded." 
his career, Clarke was among the most ardent of his admirers, and, as he supposed, of his imitators. He conceived that their minds had been cast in the same mould pictures of Byron, with open collar and massy locks, were then in the print shops, and Clarke sedulously copied his air and costume. Byron married and abused his wife. Clarke, to extend the parallel, did the same in both respects." ${ }^{1}$ He was Byron-mad, even frontispiecing his works with his own portrait, having side pose, collar and locks almost identical with Byron's, and, save for the somewhat more angular features, hardly to be distinguished from his. Much of his verse is on his personal misery, poverty, loneliness, disappointments in love and fame; much is on "world-sorrow," and on Byron. "Few," he wrote,

\footnotetext{
"Few have the strength of brain to bear

The unshadowed noon of fortune's day;

Envy's fierce insects hover there-

The worrying sting - the wasting ray,

Will fret and fever all."
}

In the same piece :-

"All lesser lights have waned before

The presence of that soul sublime [Byron];

Its blaze has reached the bleakest shore,

Throughout the darkest years of Time."

Yet he published some Burlesques on Byron (1823), when Byron had begun to burlesque himself. ${ }^{2}$

\footnotetext{
1 The New York Commercial Advertizer, Feb. 26, 1842 ; this is part gossip, but compare, "We have known more than one fool fancy himself a genius and to create the same illusion in others, quarrel with his wife and part from her to become more like Lord Byron." - Western Monthly Review, vol. iii., 1829.

${ }^{2} A$ Sketch of $M$ 'Donald Clarke (50 copies) by Clark Jillson appeared in Worcester in 1878. The author had evidently been much affected by Clarke's personal prefaces, from which all the facts for the sketch were gleaned. It is extremely crude. J. G. Wilson has a few words on Clarke in Bryant and his Friends.
} 
Attention may be called to the gloomy American Byronic lyrics with a pious ending. They were very frequent. The following is characteristically American:-

"Doth gloomy fate with sullen frown Consume thy soul with care?

Hast thou the draught of misery known, Whose dregs are dark despair?

Art thou oppressed with sorrow's doom, Thy heart with anguish torn?

$O$ soon that sad and cheerless gloom Shall make a brighter morn." 1

Sometimes the Byronic style is used for an unbyronic $\operatorname{mood}:-$

"My God! My God! how shall I speak

The transports of a bursting heart?

Not words - oh no - they are too weak -

My anguished joy they can't impart,

Feelings which cloy the tongue are mine.

Should speech essay - the utterance vain,

For holy awe and love divine

Each riven faculty enchain."

The author of this nonsense ${ }^{2}$ tried, however, in spite of "holy awe and love divine" to be pessimist:-

"Though I live for the world, I despise it, Its light is the meteor's glare, And woe to the wretch who shall prize it His portion is naught but despair,"

as well as a stoic-lover in words :-

"Farewell! forever fare thee well, Without one sigh I part;

And not one treacherous tear shall tell The anguish of my heart."

1 Poems; W. B. Tappan, Phil., 1834.

${ }^{2}$ Jay Adams, in The Charter Oak and Other Poems, N.Y., 1839. 
He was not a school boy, as one would suppose, but " engaged sedulously in active mercantile pursuits," and only "by circumstances forced over the hedge into the literary field." He trusted, he said, the reading of his book would " hasten the day when the good and the great of our land shall acknowledge the influence of soul-lifting poetry." 1

Byron's lighter lyrics were also imitated; for illustration, this of L. T. Cist, ${ }^{2}$ on a "A Beautiful Quakeress," may suffice :-

\section{" Oh! never talk again to me \\ Of dashing belles and high-born misses \\ Till it has been your lot to see \\ A meeting full of Quakeresses."}

Here is a mingling of influences from different sources (for the subject is that of an early poem of Byron, and the style that of the "Stanzas to Cadiz"), which may be instanced, in passing, as typical of a common phenomenon.

Very much affected was the lyric of gloom by the ladies. From Maria G. Brooks's early poems ${ }^{3}$ to the twelfth (!) edition of Mrs. Helen Truesdell's works, ${ }^{4}$ in spite of Moore, Southey, Scott, Mrs. Hemans, and "L. E. L.," echos of Byron are very audible. Mrs. Truesdell mentions a certain "Byrona" who

" touched a mournful chord

That vibrates every hour,

With all a poet's gentle skill,

A woman's gentle power,"

but her fame seems to have escaped even Griswold. Her "vibrations" were probably in the Annuals.

${ }^{1}$ See his preface.

2Trifles in Verse, Cincinnati, 1845. The author also imitated Burns.

3 Judith and Other Poems, Boston, 1820.

${ }^{4}$ Cincinnati, 1859. 
Many pages might be occupied with chronicling the "Melodies." One author complained in his preface, "We already have a sufficiency," instancing "Amatory," "Sacred," "Pastoral," and even "Indian Melodies "- to which he might have added "Cold Water Melodies," by a forgotten temperance advocate, Wallace. He found this, however, no argument against his own Christian Melodies. ${ }^{1}$ Almost all, as far as examined, are after Byron, rather than Moore or Mrs. Hemans. Even to-day many good Bible-reading Americans, who renounce Byron, know the Hebrew Melodies. Many verses were almost copies, as this from the fourth (!) edition of Christian Songs, by a Philadelphia pastor ${ }^{2}:-$

"The rough winds were warring on broad Galilea, And the fathomless waters rolled foaming and free, The strong blasts of Hermon came down in their might And the palms of Manasseh were bowed in their flight."

"She Walks in Beauty" and "Belshazzar" were studied with similar results.

\section{The Tales.}

With good souls of more leisure Byronic tales were a favorite employment, especially, it seems, about I830-1840. The conjugal couple, James G. and Mary E. Brooks, found time for a deal of Byronizing, but the flower of their joint labors was The Rivals of Este. ${ }^{3}$ The gloom, the crime, the nature scenes, the phrases and the meter are from Parisina, as indeed the title suggests. Yet, for an imitation, it may

${ }^{1}$ George Bettner, M.D., N.Y., 1853.

2 Rev. J. G. Lyons, Phil., 1849. Did he have a large and devoted congregation - else how a fourth edition?

${ }^{3}$ N.Y., 1829. 
rank higher than Willis' Melanie, as may be guessed from this brief extract :-

"Once more 't is solitary, lone,

Where love, crime, hatred, claimed their own,

And owlets rear their dusky brood,

Where he the dark avenger stood.

There is no death-wail by that grave,

Save as the night wind meets the wave,

And if perchance one forest flower,

Blushes in that deserted bower,

Unloved, unplucked, its beauties glow

Only for her that sleeps below."

Very Byronic tales predominate in the works of Mrs. S. A. Lewis. ${ }^{1}$ Florence, an Italian Tale of Lord Ugo's only child and her lover Leone, also recalls Parisina; this is followed by one on "Zenel,"

"a peasant's daughter, blithe and fair"

of Sunny Spain. Byron did much to popularize Spain in Europe, especially in France; the same psychological process gave America "Zenel," and may have indirectly aroused Bryant to his translations from the Spanish. This tale contains a curious admixture of the bourgeoise sentimental, neither Spanish nor Byronic; but her "Pirate," of whom

"None knew his lineage or his land

Nor when he first came to their strand, The crime or woe that drove him from His country, kindred, native home,"

brings us back to The Corsair and Lara, while her "Bride of Guayaquil" is a short Indianized Byronic tale.

${ }^{1}$ Records of the Heart, N.Y., 1844. 
For the rest, Mrs. Lewis was a cultivated lady, fond of Byron and

" his immortal wreath of woes,"

who could quote Latin and Italian, and explain Greek meters in her notes.

In " Kaughnawah" (!) Byron's hero, tricked out with feathers, knife and tomahawk, and moving with contorted visage -

$$
\text { ("a hellish scowl his visage wore") - }
$$

delivered a stoic speech

$$
\text { "on a frowning rock" }
$$

above Niagara, and then leapt over and down. The Indian of the popular imagination, about this time also very numerous in American melodrama, this proud, brave, free, vengeful, blood-thirsty, generous relic of " an extinct race which never existed," had many traits in common with the earlier Byronic hero, and the temptation to depict him in the verse of the Giaour or of Lara was not always resisted. Kaughnawah was not drowned in Niagara - at least not permanently, but space forbids our following him through the pages of other poetasters. ${ }^{2}$

Less obvious, but scarcely less frequent, was the metamorphosis of sex. Byron's women were the softest and gentlest of creatures; those of his imitators were as often also dark wretches like this same author's "Zethe," who figures in a tale of guilt, pride and thunderstorm :-

1 Zethe and Other Poems, E. D. Kennicott, Rochester, 1837.

2 Even the poor little girl, Lucretia Davidson, could write in her fourteenth year:-

"What sight of horror, fear and woe

Now greets Chief Hillis - ha-ad-joe -,

What thought of blood now lights his eye?"-

Remains, edited with biographical sketch by S. F. B. Morse ; N.Y., 1825 (?) 
"Though young in years, no roses blushed

Upon that pale and grief-worn cheek,

Those awful omens that reveal

The conflicts of a sinful soul -

O God! it was a fearful sight

At such an hour - on such a night

To view a thing so frail-so fair."

"Zethe" is thus a compound of the Byronic hero and heroine. But from other pieces in the volume we judge the author to have been an orderly, pious citizen, who desired

"A hope well anchored in the sky,"

and loved and sang his "Cottage Home" as sentimentally as Woodworth "The Old Oaken Bucket."

Mrs. E. Anne Lewis, a good mother and housewife no doubt, seems to have outstripped all her sisters in Byronizing. Her Child of the Sea (1848), on,

and

"The sorrowings of Beauty in her prime,"

"Despair untold before in prose or rhyme,"

once received some attention. ${ }^{1}$ It is modelled on The Corsair, ${ }^{2}$ with the scene laid in the Levant and personages, Zamen and Mynera, of oriental name, but it draws, too, upon the incidents in Byron's own life. Two of the cantos are headed with quotations from Petrarch to match Byron's from Dante; the third canto shows from the text and explanatory notes that she has been reading The Island,

\footnotetext{
${ }^{1}$ It was favorably reviewed by Poe with characteristic-chivalry ; see also his Correspondence.

${ }^{2}$ Edwin C. Holland, of Charleston, had remodelled The Corsair into a blank verse melodrama, (1818), preserving plot and original diction, I am told. I have not been able to see it myself.
} 
while her frequent citations from Gibbon are taken out of Byron's. It contains also many allusions to Greece, pilfered from The Giaour and Childe Harold. Her "Isabelle, or the Broken Heart, a tale of Hispaniola," is after The Prisoner of Chillon; her "Lament of LaVega," fifteen Spenserians, echoes the lines and spirit of Childe Harold, i-ii ; some extremely "Elegiac Stanzas," resulting from "Meditations on the Genius and Poetry of Letitia Elizabeth Landon," are as close to Childe Harold, iv, with at least one echo from Adonais. "The Last Hour of Sappho" was spent in mouthing heroics à la Corsair, the final plunge being described with abrupt lines, after the close of Gray's " Bard."

I will cite but the name of Emma C. Embury, ${ }^{1}$ who in her youth, over the Byronic signature " Ianthe," described "Guido," a "castle's lord," (one who

\section{Had tasted sorrow" \\ "in truth}

and who, like Lara at the ball,

$$
\begin{aligned}
& \text { "stood apart from all, - a smile } \\
& \text { Of cold contempt curled his pale lips the while"); }
\end{aligned}
$$

and the names of Elizabeth C. Kinney, who wrote Felicita, ${ }^{2}$ "a metrical Romance" of one hundred and eighty pages; of William Duff Telfer, who described the first battle of Manassas $;^{3}$ of Pliny Earle $;^{4}$ of Mary Pumpelly $;^{5}$ and will now replace the works of these estimable ladies and gentlemen, kindly and reverently on the shelves.

${ }^{1}$ Poems, first collected edition, N.Y., 1869.

${ }^{2}$ N.Y., 1855.

${ }^{3}$ N.Y., 1864.

4 Marathon and Other Poems, Phil., 1841.

${ }^{5}$ Poems, N.Y., 1852, with an introduction by Willis. 
It must be noted that the oriental tales show sometimes traces of Lalla Rookh, the Indian tales, of Scott. Scott was often an independent model, and as such as easily recognized as Byron. This from Ensinore ${ }^{1}$ is as good an illustration as any :-

"A sachem he, of high renown,

Yet not a Narragansett he, Or Delaware or Shawanee, Huron nor Ottawa his race, Nor his a Tuscaroran face; Nor led he e'er to battle forth The five fierce nations of the North."

Scott's northern clan chieftains, by the way, were not so very distantly related to Byron's Levantine pirates; the Celtic Ossian and the oriental Giaour were but two phases of the same romantic movement; and a third, it seems to me, is to be found in the American Indian, whether in Cooper, on the stage, or in such tales as these after Scott and Byron.

\section{Childe Harold.}

On the imitations of Childe Harold we may recall here the words of Goodrich and Longfellow, and the brief remarks in chapters ii, iii and iv. It is, however, only when

${ }^{1}$ P. H. Myers, N.Y., 1840.

Other imitations of Scott, without reference to merit, were :-William and Ellen, N.Y., 1811. The Lady of the Wreck (a parody), George Colman, Jr. [?] The Lay of the Scottish Fiddle (a parody), J. K. Paulding, N.Y., 1813. Jokeby, ibid. Blue Lights, J. M. Scott, N.Y., 1817. Yamoyden, Rev. J. W. Eastburn and Robert C. Sands, N.Y., 1820. (Parts are reminiscent of Byron; Sand's metrical romance, The Bridal of Vaumond is founded on the plot of Byron's Deformed Transformed.) Powhatan, Seba Smith, N.Y., 1841. The Maid of the Doe, Cornelius Matthews, [?] Washington, 1842. Tecumseh, G. H. Colton, N.Y., 1842. Redburn, anon, N.Y., 1845. Froissart Ballads, P. P. Cooke, Phil., 1847. Prontenac, A. B. Street, 1849. Monterey, Frances J. Crosby, N.Y., 1851. (She wrote a short Byronic piece in blank verse, called "The Misanthrope.") Ulric, T. S. Fay, N.Y., 1851. Marmion was dramatized by J. N. Barker, and acted in New York in 1812; see Dunlap's History of the American Stage, N.Y., 1832. 
we go to Griswold or to the forgotten works below that we learn for ourselves how numerous they were. The Byronic Spenserian became the general medium, not only for affected "world-sorrow," but for would-be eloquence on history, nature, ethics, philosophy and orthodox religion.

Its rhetorical tone appealed especially to the poetizing clergy, of whom William Allen, D.D., may be taken as representative. He was the author of Wunnisso, or The Vale of the Hoosatunnuck, " a poem with notes." Besides its ungrateful aspersions on its model-

$$
\begin{aligned}
& \text { "Byron! Idol of a giddy age!"- } \\
& * *_{*}^{*}{ }_{*}^{*}{ }^{*} \\
& \text { "Genius of immortal mind how sunk!" }
\end{aligned}
$$

and on the "vile Anacreonic notes," and

$$
\text { "sullen gleams of fierce demoniac fire," }
$$

(contrasted very fittingly with "Montgomery's congenial mind "), its heroine, who

$$
\text { "loved all nature's varying shapes" }
$$

and felt with

$$
\text { "A joy sublime her lofty mind o'erswayed," }
$$

has, though but an Indian virgin, some features of the solitary Pilgrim. The good Doctor was, for all his complacent pomposity and provincial solemnity, the distinguished President of the college which gave us Longfellow and Hawthorne.

${ }^{1}$ Boston, 1856, but written in 1826.

${ }^{2}$ Cf. The Course of Time, by The Rev. Peacock, of Scotland. 
Indian themes were a favorite with S. L. Farmer, ${ }^{1}$ who told how :-

"From Damariscotta the strong Norridgewock

Went forth and dared Pejypcot's boiling flood."

Equally burlesque is his piece on "The Disinterred Mastodon":-

"Dark mouldered relic of an elder time,"

where Byron's historic mood is expanded into the prehistoric without a corresponding expansion in poetic effect.

The majestic sadness of the past was reiterated, with pilferings also from the Hebrew Melodies, by J. Lawrence, ${ }^{2} \mathrm{Jr}$., and C. W. Everest $;{ }^{3}$ but it would be, perhaps, as fatuous and idle as the "poems" themselves were I to chronicle scrupulously every one of the authors whose volumes are piled about my desk. Here is the Rev. T. Newton Brown," who muses on time's flight and the heavenly hope; here is the Rev. Phineas Robinson, D.D., with four hundred and eleven pages on "Immortality, a poem in ten cantos;" here is the anonymous author of Song Leaves, ${ }^{6}$ who in an

" unpretending tale chimed to a broken lute,"

1llustrates the point of his preface that "poetry in weak hands is a powerless weapon," by giving us some hundred pages of Spenserians on storms, stars, politics, laudation of

1 Poems, 1830.

${ }^{2}$ Poems, N.Y., 1833.

${ }^{3}$ Babylon, Hartford, 1838.

4 Emily and Other Poems, Concord, N.H., 1840.

${ }^{5}$ N.Y., 1846.

${ }^{6}$ N.Y., 1852. 
poets and heroes, fame, freedom, retribution, castles of the Rhine and "woman's honied kiss" for which, like Byron, he "braves the world" or "commits a crime;" here is S. L. Fairfield, ${ }^{1}$ firmly believing that

"There's a cheering hope still left in heaven,"

yet wailing

"all is pain,

Our birth, life, death - and onward as we glide

We leave behind the things we love, full fain

To linger near past joys we shall not see again;"

here is $\mathrm{J}$. F. Colman, ${ }^{2}$ who somewhere in his nine cantos wails, too, how

"Shivering we grope in memory's moonless night

And stretch blind arms, which ne'er may reunite

The severed ties of youth,"

repudiating, however, Byron's irreligion and

"foul atheism's leprous stain,"

while he tries the sublime in describing Waterloo and in bidding the sun to

"roll along, on thy unsevering axle;"

here is W. T. Bacon " with his views on "Life" and Greece and Rome and hard words to tyrants, who also imitates Byron's blank verse in "A Vision of War;" here is W. O. Bourne, ${ }^{4}$ who discourses on Egypt and on

"the iron pen of time

Writing didactic lines of light and truth sublime,"

believing

1 Potical Works, Phil., 1842.

2 The Island Bride, Boston, 1846.

${ }^{3}$ Poems, Cambridge, 1848.

- Poems, N.Y., 1850. 
"that alone shall tower

Which bears diviner impress, or which springs

Where Heaven's transcendent power its life immortal flings;"

here is Charles Sangster, ${ }^{1}$ who cultivates the grand and gloomy in nature, and apostrophizes Montcalm and Wolfe, and mingles some incoalescent imitations of Shelley; here is R. T. Conrad with Devotional Poems $;^{2}$ and Lurania Munday with Acacian Lyrics, ${ }^{3}$ as melancholy and helpless as you please, in spite of the obvious influence of Mrs. Hemans; here is W. G. Dix, ${ }^{4}$ presenting us "Thoughts" and "Visions of Immortal Life;" and Anna C. Lynch," with a school composition, apostrophizing the Mediterranean, and a description of "Byron among the Ruins of Greece," embellished with an engraving ; and here is John Holland, ${ }^{6}$ grandiloquent of mountains, victories, and noble red men and Bunker Hill -

("Yet men will mingle and comment upon Thy melting legions and the wondrous day When earth revealed a second Marathon And bravery reared a new Thermopylae") -

here is Sidney Russel, ${ }^{7}$ with much to say on New England and the innocents burned on "the execrable hill" at Salem, whose other models, as he mentions in his preface, were Tennyson and Browning; here is but these should do. Yet none of these writers, it is but fair to say, was more servilely imitative, more impudently silly than a certain youth who as late as 1890 published an

\footnotetext{
1 The St. Lawrence and Other Poems, N.Y., 1856.

${ }^{2}$ Phil., 1862.

3 Cincinnati, 1860.

4 Boston, 1848.

- Poems, N.Y., 1849.

- Poems, Boston, 1858.

7 Poems, Phil., 1859.
} 
In Memoriam in that great centre of modern enlightenment, Chicago ; for the vain fecundity of American poetasters did not cease altogether when they ceased to imitate Byron.

\section{Don Juan.}

I have remarked more than once on the popularity of the Byronic Mrs. Hemans; and one has but to glance at her tales and longer historical poems, with their romanticism, gloom and pseudo-grandeur, with their French and Italian mottoes, to note affinities with Byron on the one hand, and with our versifiers on the other. The influence of her peaceful, often "prettily sentimental" poems of the affections belongs to another, though related, chapter of American verse, and is mentioned here only to make clear the distinction; imitations of these latter was the peculiar merit of Mrs. Sigourney and many Annualists. But her Byronic poetry served less for direct imitation than as an influence for the imitation of Byron, in fostering his subjects, moods, methods. Only rarely, as in some slight deviation from the regular Spenserian stanza, in some phrase or quotation, is she directly imitated. Byron, himself, is the model toward which she drew her admirers. With imitations of Don Juan we have an analogy and a difference. Halleck's Fanny was contemporaneous with Don Juan, and seems to have been only less popular. It not only inspired many to imitate its models (Beppo and Don Juan), but served itself quite frequently as a model; yet it seems fair to group the imitations of Fanny here along with the more patent imitations of Don Juan. Frequently characteristics of title, plot, satire and stanza are after Fanny, but the self-conscious buffoonery, the com- 
placent irony, the conceited familiarity with gods and men, the direct allusions to Byron rather than to Halleck, all indicate the dominance of the former.

An early instance is the Sukey ${ }^{1}$ of W. B. Walter-a degenerate great grandson of Increase Mather, and (as the opening stanza has it)

"One of those melancholy men, Who sometimes like to strike a harp of sadness,"

with whom we have already become so familiar. But Sukey

$$
\text { "was a village girl - an orphan child" - }
$$

who got mixed up with pirates, and came to a tragic end. The copy examined had once belonged to Jacob Abbot, and his marginal pencilled comments and illustrative drawings are at least as readable as the text. Walter had written :-

"I never shrink

From giving my opinion"-

Abbot comments " no one doubts this." The line on a

"Solemn glen where peers the place of graves"

is adorned with a clever caricature of a village churchyard. Abbot further points out with mock solemnity some curious metamorphoses in the color of Sukey's hair, yellow-brown at the beginning, raven black at the end. Walter has (like Halleck) some stanzas of asterisks - the commentator writes "Very fine-you are pleased to be facetious." Abbot also notes some flagrant thefts from John Neal's “Maniac Harper.” We may judge, then,

${ }^{1}$ Boston, 1821. 
that, if there were fools who wrote such things, not all were fools who read them. Walter's notes, though largely taken up with traitorously exposing Lord Byron's " pilferings," ape his critical style and opinions. In the same year our author published a volume of Byronic lyrics, dedicated to Pierpont - which - if we are to believe his preface - "contain specimens of the precious and melancholy toil of years." He trusted "posterity" would "illumine the shrine that consecrates his fame." If posterity has been busy elsewhere with its candles, his contemporary fame at least was consecrated by a third edition of Sukey in Baltimore the same year, and by "the late William Crafts," who wrote "Kitty" - with the justification, "In New York they have Fanny; in Boston Sukey, and why should we not have Kitty in Charleston?" Of Kitty, I may say, it was a little better than Sukey. Thus the following stanza from the former will enable us to judge the quality of each :-

\section{"I love a horseman on a likely horse But precious few of these, alas! there are; I have seen better, but I ne'er saw worse For either purpose, whether peace or war. 'T is rather strange, since every one is able To hire a good one at a livery stable." 1}

The year after Sukey, New York saw a prose dramatization of Don Juan, ${ }^{2}$ in which the Sultana, conquering her hopeless passion, generously unites Juan with Haidee, who has followed him in male attire.

${ }^{1} \mathrm{Mr}$. Crafts has also borne witness in prose to his studies of Don Juan. He once commented: "How shall Poetry - the refined companion of the Graces and Virtues, with Honor on her brow, Inspiration in her bosom and Immortality in her right hand - palliate her abandonment of her high destiny and polluting intercourse with Sin and Infamy? "Quoted by Legaré in Southern Review for May, 1828.

2 The Sultana, or a Trip to Turkey. Anon. [Bailey], N.Y., 1822. 
Isaac Starr Classon, author of Horace in Neze York, wrote a continuation of Don Juan, ${ }^{1}$ in two cantos, with the same manners, morals, opinions, style, and even story, in which "her frolic grace Fitz Fulk" succeeds to the indiscretions of Julia and Haidee and the Duke to the indignation of Don Alphonso and Lambro; and though he indulges in a good many asterisks, there are some boldly printed stanzas almost rivalling the original. He bolsters out his notes with cribbings from Byron's - a trick now so familiar to us that it is scarcely worth mentioning more; to the line

$$
\text { "To give an infant inclination play" }
$$

he comments, "All minors are termed infants in law," just as Byron had commented to

$$
\text { "In law an infant and in years a boy" }
$$

in the Hours of Idleness. A passage on Napoleon is the best.

We sometimes come upon a fusion, or confusion, of Don Juan and Childe Harold, as in "The Minstrel Boy" 2 of that deaf and dumb prodigy, James Nack, who "had a better knowledge of rhyming words than any poet living;" he grafts the moods of the latter on the ottava rimas of the former. So, too, in The Lay of the Last Pilgrim, " "by the author of The Pilgrimage of Ormond," which is in Spenserians, but a medley of Childe Harold moods and Don Juan familiarity. Here, too, belongs Childe Har-

${ }^{1}$ N.Y., 1825 (second edition). There were several published in England: "The Last Canto of the Original Don Juan," from the papers of the Countess Guiccioli, London, 18-; Don Juan, Jr., a poem by Byron's ghost, London, 1839; Sequel to Don Juan, London, 1843 (second edition). Fourteen stanzas of Byron's own continuation are now first printed in E. Hartley Coleridge's edition.

${ }^{2}$ In The Legend of the Rocks and Other Poems, N.Y., 1827; the title piece is in Scott's octosyllabics.

${ }^{3}$ Charleston, S.C., 1832. The title is Byron and Scott. 
vard, " a romance of Cambridge," in four cantos with stanzas rhyming ababcc. It was evidently done by a college senior of ' 48 , and satirizes rather amusingly Harvard's little world of pedants, proféssors and pupils. Among the interspersed songs are burlesques of Longfellow. ${ }^{2}$ The Ianthe $^{8}$ of Carlos D. Stuart combines in octosyllabics the Juan pathetic Haidee episode with the terror and darkness of the earlier tales.

But by far the most marvelous Byronic production has yet to be named. It was the Geraldine 4 of Rufus Dawes, one of "that constellation of poets that has lately risen to the view of the American people, a constellation that admits a mild and lovely light." 5 From the publisher's "Advertisement" we learn that "the Ms. had been purchased, and subscriptions had been taken with flattering success," though the plan had been later abandoned. Poe called it " most inflated, involved and falsely figurative"- he might have added unwittingly burlesque and melodramatic, shamelessly and crudely imitative. There is hardly one popular passage of Don Juan or Childe Harold that has not helped to furnish out Geraldine; hardly an idea, a sentiment, hardly a phrase, even to the jest

$$
\text { "thine incomparable oil, Macassar" }{ }_{6}
$$

only the hopeless inanity of the plot and the opinions on Byron, as far as they were not characteristic of the times,

\footnotetext{
${ }^{1}$ By Señor Alguno (Nathan Ames), Boston, 1848.

2 As "To a Polywog" :-

"Thou has taught me what a lesson!-

That like thee, I too must press on,

While my bones retain their flesh on,

${ }^{3}$ N.Y., 1843.

Wiggle waggle, waggle wiggle."

4 Library of American Poets, N.Y., 1839.

${ }^{5} \mathrm{Knapp}$, Sketches of Public Characters.

6 i. 17.
} 
were his own. Byron was "self-abased," and "the problem of humanity;" and Shelley is coupled with him as

"Without the Palinurus of self-science"

embarking

$$
\text { "upon the stormy sea." }
$$

The hero, Waldron, is a bourgeoise Byron, somewhat like Neal's Morton -

$$
\text { His mind had freely wandered," }
$$

and

$$
\text { "Reason he deemed could measure everything," }
$$

yet

$$
\text { "the stir }
$$

And boiling eddies of uncalmed desire

Buoyed up his swelling breast."

"And now he recked not but of pleasure's stream."

Sated he sought new scenes - and the "mælstrom of fashion":-

"Within the busy vortex Waldron moved And drugged his sense of woe."

Meantime his newly roused love for Miss Geraldine is only too deeply shared by one Clifford ; and this emotional complication produces a chain of circumstances, ending in a ball, with Clifford at the bottom of a lake and Waldron on his way to join the Corsairs. Geraldine peeks and pines, her father takes her South, on the way their ship is attacked by Corsairs and wrecked, and Geraldine and her father put off on a raft. But some of the Corsairs have got astray, too, and are floating about in the longboat, dying of thirst and starvation till only one remains. The raft and the boat meet, of course, just when

"The moon is shining full upon the wave." 
Geraldine lies dead in her father's arms, with Waldron's picture hanging from her bosom. The sole survivor from the longboat

$$
\text { "wildly flung }
$$

His arms around her with a mad'ning [sic] throw, Then plunged within the cold unfathomed deep, While sirens sung the victim to his sleep."

Here the tale ends; what became of the father we are not informed. The author at times tried consciously to be facetious - but he builded better than he knew, as this mixture of Don Juan and the dime novel may attest.

Arthur Carryl, ${ }^{1}$ by Laughton Osburn, though - or rather because - far more respectable, need not detain us, except, perhaps, for the observation that, like Willis' Lady Jane, it purports to be a novel.

The Paradise of Fools, ${ }^{2}$ on the other hand, is strictly a literary satire on contemporary America. Though it imitates Don Juan, even to the jokes, calling, for example, freebooters and pirates fishers of men, ${ }^{3}$ the burlesque situations remind us more of The Vision of Judgment (as the debate over the candidate for admission to the Paradise and the dull bard reading his poem aloud before the Court till all are prostrated). Of the authors mentioned, Willis undoubtedly fares worst. The candidate is finally refused admission - for

"They said I'd have to read what W-1l-s wrote . . . . before I could be fit

Within the Paradise of Fools to sit."

"And so they sent me back upon a comet To earth to study well 'The Lady Jane' And learn to be a perfect ninny from it."

\footnotetext{
1 N.Y., 1841.

2 Baltimore, 1841.

${ }^{3}$ Don Juan, ii, 125.
} 
It is a comparatively clever jeu d'esprit, whoever the author.

Brief reference may be made to John A. Shea, author of "Adolph," the character of which may be judged from the opening lines:-

"Well truth is strange, aye even than fiction stranger." ${ }^{2}$

George Rogers, ${ }^{3}$ a renegade Englishman, celebrated Washington in one hundred and sixty-four pages, the dignity of his theme putting a curb on frivolity, but not preventing excursions into contemporary politics, and the inevitable imitation of the famous " "T is sweet." We have also Guadaloupe," "a tale of love and war," based on incidents of the Mexican war, with much familiar digression, its anonymous author going out of his way to villify Wellington, apparently merely because Byron had done so. The Dutch Pilgrim Fathers, ${ }^{5}$ by Edward Hopper, in ottava rima, in intent comic rather than satiric; and The Vision of Judgment, ${ }^{\circ}$ which describes some obscure church-squabbles in three cantos of very close imitation, often verbatim copying, of Byron's Vision, may close the list.

Legaré had remarked long since, "Lord Byron with his Beppos and Juans has done infinite mischief in the rhyming world. Nothing is so easy as to rival the noble poet in his slip-shod, zig-zag, desultory style, and doggerel versification, but nothing is more difficult than to pour out with such perfect nonchalance strains of the most

${ }^{1}$ In Poems, N.Y., 1846.

${ }^{2}$ Cf. Don Juan, xiv, 101.

${ }^{3}$ In Democratic Vistas, N.Y., 1849.

"Philadelphia, 1860.

${ }^{5}$ N.Y., 1865.

${ }^{6}$ R. W. Wright, N.Y., 1867.

'In reviewing Craft's Writings in the Southern Review, 1829. 
beautiful poetry and sallies of incomparable wit. The humor of a man of genius, however eccentric and even extravagant, is one thing, and the buffoonery of an awkward imitator quite another."

When Byron's influence waned, the same change of model is, of course, to be noticed as specified in the last two chapters. The situation at the turn of the sixties, or thereabouts, is capitally portrayed in Holmes' Guardian Angel:- " He [Gifted Hopkins] retired pensive from this interview, and flinging himself at his desk, attempted wreaking his thoughts upon expression, to borrow the language of one of his brother bards, in a passionate lyric which he began thus:-

\section{'another's!}

Another's! O the pang, the smart!

Fate owes to love a deathless grudge -

The barbed fang has rent a heart

which - which -

Judge-judge, no, not judge-budge, drugge, fudge ! . . . all up for to-night!'

... 'O no, Mr. Hopkins, pray go on,' [he is reading his verses] said Clement, 'I'm very fond of poetry.' The poet did not require much urging, and recited :-

\footnotetext{
'She moves in splendor like the ray That flashes from unclouded skies, And all the charm of night and day Are mingled in her hair and eyes!'
}

Clement . . . said the stanzas reminded him forcibly of one of the greatest poets of the century. Gifted, flushed hot with pleasure... Perhaps you will like these lines still better... the style is more modern :- 
'O daughter of the spiced South!

Her bubbly grapes have spilled the wine

That stained with its hue divine

The red flower of thy perfect mouth'-

and so on through a series of stanzas like these with the pulp of two rhymes between the upper and the lower crust of two others." Gifted Hopkins, as we have seen, was drawn from life. ${ }^{1}$

1 But a quotation from Goodrich's Recollections opened this chronicle, and it is fitting that another should conclude it: "At the present day the flood of license is subsiding. Byron is still read, but his immoralities, his atheism, have lost their relish, and are now deemed offenses and blemishes, and at the same time the public taste is directing itself in favor of a purer and more exalted moral tone..... Longfellow, Bryant and Tennyson, are the exponents of the public taste in poetry, and Hawthorne, Dickens, Thackeray in romance." 


\section{CHAPTER VI.}

BYRON IN AMERICAN CRITICISM.-SOME EXPLANATION of Byron's American Vogue.-Conclusion.

$\mathrm{SUCH}$ in brief is the chronicle of Byronic verse in $\int$ America. Were it to be brought down to the present day, very few names of sub-literary writers such as have just been dealt with, and only one name, Joaquin Miller, of equal rank with those earlier writers grouped under Chapter III, could be added. With the diffusion of a relatively higher culture at home, and the rise of new poetic tastes in England, the vogue of Byron had passed, and that, too, before the appearance of Mrs. Stowe's charges, which in popular thought are supposed to have been instrumental in checking it. Joaquin Miller is the only American poet, except Halleck, who has loved Byron romantically without silliness. Out in the bay of San Francisco, " forever green in its crown of California laurel, the fairest hands of the youngest and fairest city of the New World wove a wreath of bay for the tomb of Byron," which the following days Miller "brought over the Rocky Mountains, and the seas and placed above the dust of the soldier-poet." 1 He is almost the only American poet, except Halleck, who has been inspired by Byron to genuine poetic achievement. His Californian, ${ }^{2}$ an Indian tale of revenge, is a wild gorgeous Giaour of the Sierras. But Miller stands somewhat apart from the movement we have been tracing.

1 Prefatory note to the poem "Burns and Byron," Songs of the Sierras, 1871.

2 Sings of the Sierras. 
From the verse which records this movement, it may be said in summary, we have seen the influence of Byron's personality, opinions and poetry upon a somewhat unsophisticated and crude people. ${ }^{1}$ We have seen the Byron collar, the mysterious mien, imitated in person or on paper; we have read pessimistic views of life; we have seen his elements of poetic matter, the literary satire of The English Bards, the wild adventures of the tales, the nature and history of Childe Harold, the solemn isolation and communion of Manfred, the love and despair of the lyrics, the social satire and wit of Don Juan - we have seen all these imitated with also an even more pronounced imitation of the elements of poetic manner, the rhythms, the rhymes, the stanzas, the general form and even scattered phrases. In some of this verse we have read, too, the views of the opposition, with direct testimony that Byron was occupying a deal of attention. In Chapter II, touching Byron in the newspapers and magazines to the time of his death, and in occasional quotations and foot-notes of the succeeding chapters, the reader will have noticed also some prose criticism; there still remains, however, somewhat to be reported under this head.

I.

Byron's death occasioned much serious criticism, which continued for two or three years thereafter. The publication of Moore's Life and Letters in 1830-I occasioned Macaulay's brilliant essay in England, and in America at

1 The crudity of American intellectual life has been frequently referred to in these pages, and is too well known to need further proof. Yet as a work of supererogation I may transcribe another word from Goodrich, who was in his day with Griswold in the forefront of American intellectual enterprise. He gives in his Recollections elaborate statistics to show, the increase in school-books, from an aggregate of $\$ 2,500,000$ in 1820 , to $\$ 12,500,000$ in 1850 , and adds triumphantly, "Then, I ask, have we not a literature?" "We produce annually more school-books than the whole continent of Europe." Goodrich has recorded also his impressions of a visit to Rome :- "The Forum, the Palace of the Cæsars, the Coliseum, the Baths of Caracalla ... display the actual poverty of art, for there is not one of them that can furnish a useful suggestion to even a house-carpenter .... the aqueducts ..... look like lines of marching mastadons." This was innocence abroad, indeed. 
least one critique of first-rate ability, that of Legaré. Lady Byron's death and Mrs. Stowe's "vindication" renewed the old discussion of Byron's character, but resulted in nothing, I believe, on his writings, except disputes as to the interpretation of some passages of supposed self-confession. Byron's centenary ${ }^{1}$ yielded a rather cold essay by Professor Woodberry, and since 1898 , the volumes of Henley and of Prothero and Coleridge have called forth the essays of Mr. More and Professor Trent, already referred to. ${ }^{2}$

The first extended discussion of Byron's completed achievement appeared, as before stated, in the North American Reviez, shortly after his death. A few months later appeared there a discussion, still more extended, which was immediately honored with republication in England to serve as an antidote to the evil spirit of Byronism. It was written by Andrews Norton, and remains to this day among the more independent and profitable, though less known, studies on the poet. Norton was very conservative. As a clergyman, he condemned, naturally enough, the immorality and irreligion both of Byron's life and of his writings; and stripped off the often all too unreal romance from his sorrows, doubting not, however, that he suffered from a gloomy temperament and from the depressing physical effect of his vices, but this was, on the whole, "a vulgar misery;" even his espousal of the Greek cause was "theatrical." The critic denied the ideality of Byron's great poetry: "It is the poetry of earth only where it is not, as in Cain, the poetry of hell."

\footnotetext{
1 Scott's centenary was celebrated in Boston with tributes from Holmes and Emerson.

${ }^{2}$ Professor Bülbring of Bonn told me the renewed interest in Byron in Germany University circles was due chiefly to the wealth of scholarly material in the edition of Prothero and Coleridge. Quite noticeable is the large number of German dissertations for the doctorate on Byron during the last five years.
} 
This poem, with Don Juan, was " a course of writing which left nothing to be hoped." Norton was utterly oblivious of the deep spiritual doubts and splendid imagination of Cain, which made it on the one hand great literature, and on the other great poetry ; in Don Juan he saw, like Southey, only ribaldry, buffoonery and blasphemy against God and man, but felt not, as did such a healthy spirit as Scott, its abundance of observation and experience, its understanding of the weaker sides of humanity, its sublime irony, its jovial laughter, its wealth of language, its gayety, its pathos, its command of all moods, which make it, too, great literature and great poetry. In fact, Don Juan has seldom been understood by Englishspeaking critics. Byron's popularity he assigned - and in part justly - to his being en rapport with his times. In such observations there was nothing unusual or extraordinary; but Norton undertook a purely æsthetic judgment, which yielded an almost equally negative result. Because Byron, the man, he contended, had no fixed principles of belief or of action, Byron, the poet, was not " in real harmony of mind with the works of nature;" his artistic defects sprang in the main from an unsound moral fibre $;{ }^{1}$ thus much of his most admired work was forced exaggeration and "factitious sentiment;" he was successful and sincere only when describing moods of nature, gloomy like himself, where " his intense egotism made him a poet." Some passages in Childe Harold arè examined in detail from this standpoint. Norton is subtle; and many thoughtful persons, who hold that great art is only possible with great character, would agree with him, without stopping to examine where his subtlety leads to the exploiting

\footnotetext{
1 He anticipates the more brilliant utterance of Cardinal Newman, who in his Essay on Poetry, applies the same reasoning to the same poet.
} 
of mere idiosyncracies of taste, or involves a failure to perceive that the momentary heat of imagination and emotion in a creative genius is itself sincerity.

Hugh Swinton Legaré, one of the most, perhaps the most, accomplished of Southern gentlemen ${ }^{1}$ before the Civil War, published two extensive articles in his Southern Review," as the two volumes by Moore were reprinted in America, on "Byron's Character and Writings." In those days Byron, the man, offered the critic as many, if not more interesting, problems as Byron, the poet. Legaré, with the chivalry of his race, defended Byron's mother and wife, and condemned the poet as most unfilial and unuxorious. He contrasted Byron with Scott:- "Never did two such men - competitors in the highest walks of creative imagination and deep pathos - present such a strange antithesis of moral character, domestic habits and pursuits, as Walter Scott at home and Lord Byron abroad." Of Don Juan he remarked:- "In writing Don Juan Byron renounced-renounced with foul scorn and beyond all hope of recovery - the sympathies of mankind . . . . the wanton, gross and often dull and feeble ribaldry of some of his latest productions, broke the spell which he had laid upon our souls." Here the Southern litterateur and the New England clergyman are strangely in accord. The spell had controlled Legaré " less than two lustres ago," and then Legaré "could never think of him but as an ideal being." It is hard for us to realize to-day with what a shock of disenchantment Don Juan affected the more idealistic of Byron's admirers; they felt as if they had been grievously imposed upon, and cheated of their generous enthusiasm and sympathy. ${ }^{3}$ Legaré found the main-

1 For Poe was hardly a Southerner, and Simms was not notably accomplished.

See Writings of Legaré. 2 vols., Charleston, 1845.

${ }^{3}$ See even the Edinburgh Review. especially the first article on Don Juan. 
spring of Byron's character and writings to have been debellare superbos, and his chief peculiarity - he does not say defect - as a poet, in his similes: "Instead of drawing his similes from the natural world to the moral, as the ancients uniformly did, he does just the reverse. Thus a 'lake' is 'calm as cherished hate,' Zuleika was 'soft as the memory of buried love." ... "Manfred as a whole is his masterpiece."

Rev. W. B. O. Peabody reviewed Moore in the North American Review, ${ }^{1}$ but voiced only current opinions. He reprehended Moore for linking unhappiness and genius together; Byron's moral defects could not be palliated on that score. The tales were "shocking to probability;" and "Childe Harold was his most important work, and on this and his lyrical poems his fame must ultimately depend." There is no mention of Don Juan. Peabody, in another article in the North American Review " on "English Poetry in the Nineteenth Century," thought "the perversion of Byron's genius scarcely inferior to that of his moral powers."

E. P. Whipple discussed "The Characteristics of Lord Byron" in the same Revieze for 1845 . Byron was "the mouthpiece of the harsher revolutionary spirit of the time ;" and a man of whom "it may almost be said he had no character at all." Whipple also entirely misunderstood Don Juan, and in rebuking "the scoffing demon of his wit" he quoted the whimsical and charming verses (ii, I44) where Haidee leaning over young Juan in the cave,

$$
\text { "drew out her provisions from the basket" }{ }_{3}
$$

as degrading to poetry.

\footnotetext{
${ }^{1}$ See Literary Remains, Boston, 1850.

2 Vol. 1, p. 494.

3 ii., 144.
} 
"Byron and his Contemporaries," by H. J. Brent, in his National Magazine for 1839, illustrates the fulsome and undiscerning adulation of some minor critics. It was Byron's romantic life that appealed most to him, and he sided with Byron against his wife and the public. The criticism of his poetry is askew. He calls, as some German philologians have called, Childe Harold an epic, and says "Byron is classical - all his poetry is of the Grecian order - it is the verse that we might suppose some Athenian of the Platonic era would have written beneath the groves of Academe." There was a classical element in Byron's imagination, in the distinctness of his metaphors and in the simplicity and scope of his designs, but Mr. Brent evidently meant something very different. And wishing to compare Byron with the world's greatest painter he hit on - Salvator Rosa.

In The Mirror for 1837 , another minor critic, William Cox, taking offense at some strictures " in a few back numbers" of that once popular journal, defended Byron against " the charges usually brought against his poetry, on three counts:" firstly, his skepticism was not proselyting; secondly, his licentiousness was confined to Don Juan, and never as atrocious as a certain scene in the highly respected Seasons; and thirdly, his disreputable heroes always come to a bad end.

The Transcendentalists would none of Byron; Emerson in the Preface to Parnassus, half admiring a rhyming facility which he possessed not himself, conceived Byron's lack of any aim a fundamental limitation. Margaret Fuller believed " his poems have done their work, and are beginning to find their proper level . . . posterity will assign him an obscure place." Wordsworth, to whom she gives the most space in her list of poetic judgments, was 
"the greatest poet of the day." $\quad$ That the serene singer of the inner life and the light that never was on sea or land should have spoken more intelligibly and beautifully to this band of high, quiet souls, living with the Immanent on New England hills and meadows, than the passionate spirit crying in the night for a light beyond him, or passing feverishly over old cities of ruin and modern society, with its complex contradictions of high and low, was, of course, only inevitable.

Yet if, according to Margaret Fuller, Byron's poems were finding "their proper level," according to Henry T. Tuckerman, about the same time, "Three thousand copies of Byron's poems were sold annually in this country." Tuckerman's essay ${ }^{2}$ is characterized by sense and insight. The analysis of Byron's character, his foibles, his vices, his inconsistencies, his generosity, his frankness, the part played by heredity and environment, while not profound, marks a change in the critical spirit. He saw truly that "there is a vast deal of cant in much that is said of the moral perversion of the poet," and strove to counteract it. Of Byron's poetry he wrote, it seems with some degree of originality and truth :- "Byron represents an actual phase of the soul's life; not its whole nor its highest experience, but still a real and most interesting portion of its development. . . . In many a youthful heart do his truest appeals find an immediate response. . . . How much of lofty promise in the very discontent he utters . . . . how often does it reveal an infinite necessity for love, an eternal tendency to progress .... and the eloquent complaints of Byron have brought home to countless hearts a deeper conviction of the absolute need of truth and self-respect

1 Papers on Literature and Art, London, 1846.

2 In Thoughts on the Poets, London, 1850. 
than any logical argument. . . . . If a few shallow imitators are silly enough to turn down their collars and drink gin, there is another class who mentally exclaim as they read Byron- 'What infinite longings are these, what sensibility to beauty, what capacities of suffering!"”

Later criticism has dealt more and more leniently with Byron's woeful shortcomings as a man, or sunk them altogether in a consideration of his poetry. Again, the "atheism" in his poetry - about as real as that of The Book of Job-and its immoralities, which cannot be so easily defended, have long since ceased to be an important issue with critics.

But in no American criticism, except in the brief and crude observations of Goodrich, is there any attempt to explain Byron's vogue in America, as in any way of the country and not altogether of the age. It is doubtful if even an acute observer could then have seen our literary conditions in the broad way to-day quite possible even to the most ordinary mind acquainted with the facts. There were many in those days who realized "the difficulties of a national literature:" the need of copyright, the provincial reverence for any English book, however mean, the lack of an intellectual centre like London or Paris, the incompetence of minor criticism and the American versatility, which conceived itself, because apt in politics, stump-speaking, carpentry, plumbing, boat-making, distilling and extempore praying, therefore equally apt to "turn off in leisure moments" an Indian Epic of six cantos after Scott or Byron, a quarto of songs like Moore's, or a string of Byronic Spenserians. ${ }^{1}$ Edward Everett, Verplanck, Hal-

1 This complacent versatility was most crude in the West, which by the forties was as much irritated by the relative superiority of what it was pleased to call "The cheap Atlantic retailers in literature" (Western Monthly Magazine), as the East had been irritated, scarcely a generation before, by the infinite superiority of what it was sometimes pleased to call "the loathsome filth of Scotch reviewers" and "Lord Byron's mercenary critics." This Western Monthly Magazine (Louisville and Cincinnati) proclaimed in the April number of 1837, "Notwithstanding the devotion of Ohio to pork, railroads and banks, and of Kentucky to tobacco, hemp and stock, we are doing a pretty fair business out here in the literary line." 
leck, Bryant, Longfellow, Timothy Flint, Willis, Cornelius Mathews, Poe, and many another reiterated these limitations again and again. But the more far-reaching limitations, the defective imaginative background of a long past, colored rich with multifarious life on coast and plain and mountain, the defective national experience, the only just born national character, and the natural absorption of the energies of a new people of a new land in felling forests, in laying out acres, in building wharves and warehouses, have been, I believe, first realized and formulated since they have been to some degree overcome. So with the vogue of Byron. Critics seem to have seen in it no more than the spirit of the times and the silliness of mankind. To-day, when one has followed it down two generations, when one has followed too, the obscure ins and outs of thousands of old newspapers, magazines and pamphlets, and hundreds of old books in prose and verse, recording the general intellectual conditions, one can judge with more discrimination.

II.

Yet one must not forget or disregard the universal in time or in humanity for the sake of establishing a particular thesis. Byron's vogue had much in common, as already admitted, with his vogue elsewhere; it is, indeed, in part to be explained on the one hand by the spirit of those times which were restless, stormy and gloomy, and on the other by the silliness of humanity which in every age will imitate a great leader, especially when there are in him the attractions of beauty and romance, or any suggestion of eccentricity. ${ }^{1}$

\footnotetext{
1 Did not the silly Roman advocates walk about the Forum with necks awry, because Cicero's wen made Cicero walk so? And have not most German officers and German corps students to-day an "es-ist-erreicht" moustache because the Kaiser has chosen to wear one?
} 
The spirit of the times on the Continent, to some extent in England, was, as before observed, quite the reverse of that in America. Yet America, though herself in the very era of new-found strength and good feeling, was keenly alive to Continental thought ; and something of the Continental mood tinged her intellectual life. The French Revolution had its American supporters, and there was a bond of union in Lafayette; French infidelity - one needs but to recall Thomas Paine - had spread among us, and even in such a staid institution as Yale, under the staid Timothy Dwight, existed free-thinking societies whose members abandoned their own Christian names to masquerade about the campus as Diderots and Voltaires; the Napoleonic wars were duly reported in the papers; Napoleon had his American enemies and his champions, as the readers of John S. C. Abbot well know; the Greek struggle occupied Daniel Webster in the Senate. Though America could not feel with the living experience of France, Germany, Italy, Spain, Russia, and Byron as an incarnation of the Time-Spirit (Zeitgeist) could not in consequence be an inspiration to any sincere American poet, living the life of his country, yet America possessed fully and understood not unsympathetically the main facts necessary to the interpretation of this Byron of the Time-Spirit.

And the vogue of Byron in America depended in some measure also on the same literary conditions as in England. The literary past of England was, as we have seen, the literary possession of America. Byron's contemporary success and fame in England, as opposed to the contemporary failure and obscurity of Wordsworth and Keats, lay not a little in his literary conservatism. He is much less revolutionary than is popularly supposed. He followed directly on Gifford in literary satire ; he adopted the Spen- 
serian of Beattie ${ }^{1}$ and Campbell and the octosyllabics of Scott. The melancholy had traits in common with that of the "Grave-Yard School," and sadness had been cultivated by the Sentimentalists; his mysterious heroes with much of their equipage were already fore-shadowed in the Tales of Horror of Radcliffe, Lewis, and Maturin; his didacticism was far more in the spirit of the past than of the future; something of his nature mood was already familiar in Rosseau and Chateaubriand; and his irreligion never shook itself quite free from Calvinism. His Don Juan was in part a parody on the styles of poetry he had himself made only more popular; and it was written in a verse for which the public had just been prepared by Frere's "Whistlecrafts." Yet only the most superficial judgment could deny Byron creative power on this score, nor was his poetry merely the fostering of fashions. He stood to the lyric poetry of his age - employing the word in its broadest sense for all subjective poetry - as Shakespeare had stood to the dramatic poetry of Elizabethan times. It may be that the greatest poets always make in this way increment of the past and present. What of new he added was that inexpressible something pre-eminent which made it possible for him to crystalize into poetry, not only the spirit of the times in life and politics, but its spirit in literature as well. But this point is touched on not to eulogize Byron, rather to point out its significance for America. Our fathers had the literary key to Byron, at a time, when, as in England, Wordsworth was caviare to the general and critic alike, and Keats was a cockneymannikin, and neither would ever do.

These facts aside, the silliness of humanity must have been one factor, if not in the admiration, at least in the

${ }^{1}$ Childe Harold, $\mathrm{i}-\mathrm{ii}$, has some marked similarities with The Minstrel. 
imitation of Byron. For that many good people could read poetry with more intellect and feeling than they could write it, and that the intensity of Byron's real spell cannot be measured by the flabbiness of most imitators, it can be taken for granted. But let us look a little closer.

Scientific certainty is almost impossible in the literary biography of an individual; much more so in a chapter, however brief and simple, in the literary biography of a nation. It is even impossible to determine surely in what section of the country or at what date Byron was most popular. Authors writing in one place seem frequently to have published in quite another, and the date of publication may not have corresponded by a decade or so to the date of composition. Possibly, gloomy moralizings in Spenserians predominated in New England, pseudo Don Juans in and about New York, literary satire in Philadelphia, tales in the West and South ; this would correspond, moreover, fairly to the peculiarities of the respective districts. After Byron's death, when the furore manifestly subsided, the dates of Halleck's edition (I835-7) may denote the high-water mark of popularity. Still more when dealing with causes must one rely on impression and insight. Byron's effect on America may perhaps be best understood with reference to his well-known effect on the young. What is meant by this, a moment's reflection will make clear.

The ethical sense of the individual precedes in development the æsthetic sense; the boy admires high words and deeds, and the ringing verse that has moral strength, rather than sensuous beauty; he admires, in other words, the biography and history of great achievement, loathes the base, and sympathizes with defeat and ruin. And his lit- 
erary delight is eloquence - always in its essence ethical. He can recite with power "The Isles of Greece ;" but he can see nothing in "An Ode on a Grecian Urn." Moreover, his ethical ideals are grand rather than subtle or simple. America before the Civil War, with her Washington, her Declaration of Independence and the moral foundations of the Republic forever in her mind's eye, with her race of orators in the Senate, in the House, in the pulpit and on the village green, with her frame schoolhouses and shabby board walks, with her Ionic porticos of granite or gray-sanded wooden props, had a far higher ethical than æsthetic life. Now, Byron, more than any contemporary, had the grand, eloquent ethical note.

And just as the young by that temporary perversion of the moral life, which is almost sure to follow awakened self-consciousness; find something manly in swearing or smoking a cigarette, so at times, it seems, the unsophisticated American of the earlier days found something peculiarly fascinating in Byron's perversities. Yet it may be apropos here to remark that the sexual immorality in Byron's poetry is not at all the prime source of his effect on youth. It serves to stimulate curiosity, especially if the schoolma'am sounds a warning; but the real fascination, if the explanation I am here giving be correct, is quite different. Nor was it an important source either of his earlier popularity or of his later decline in America.

Just as the young have a romantic craving for what is most remote from their own experience, be it for daggers, murders, pirates, treasure-trove, cowboys or castles; so America, inexperienced and prosaic in spite of explorations, settlements, Rocky Mountains, a war or two and a beautiful banner in the blue sky, seems to have felt a peculiar charm in the East, and in the bizarre performances 
of Byron's heroes and of Byron himself, even as to this day her religious bodies are more interested in foreign than in domestic missions.

Again, the boy is undoubtedly drawn to Byron not a little by the force and sweep and untrained will of his utterance; Byron had the rapidity and the recklessness which the reading boy often most delights in, as voicing himself. It may not be a mere fanciful analogy to suggest that this element in Byron may have had a peculiar power over the force and sweep and untrained will of the young nation. But this must not be confused with the Titanic power of his revolt and "impatient democracy" over contemporary nations and conditions in Europe.

These brief considerations concern in part simply the readers of Byron. He made imitators also by his appeal to self-consciousness. The normal boy feels a kinship with Byron's greater spirit, with Byron's aggressive egotism and pride, and often with his melancholy and revolt; not because of deep conflicts and afflictions in real life, but because he is in the confused transitional stage between existence as a matter of course and his own existence, half recognized as personality. He is over-conscious of himself, and blushes when his mother introduces him to the new minister. He reads Byron (in secret) and, if he be ambitious and conceited, two traits presumably at their acme in this period of his life, he will imitate Byron. Most of our imitators, though elder in years, were, as writers, in this self-conscious state. They were conceited in provincial inexperience, and ambitious to achieve beyond their power; while the country at large was in the most self-conscious period of its development (as shown not more by its boastfulness than by its sensitiveness to criticism and by the general decision in favor of a national 
literature). Byron, not only the great exponent of personality, but the most self-conscious, was thus, the one contemporary English poet - as before hinted but as now quite manifest by virtue of the verse we have just left behind us - most attractive as a model when literary perfection was still quite generally aimed at by copying English poets.

Another reason, so obvious that one is in danger of missing it altogether, is this: the very obviousness of Byron himself. Excepting passages in Childe Harold, iii and iv, Byron is one of the most intelligible and straight-| forward of poets. Subjective poetry, broadly speaking, is either symbolic or direct. A subjective poet may express himself, his moods or opinions, in terms of dramatic monologue, as at times did Browning, or through some aspect of nature, as did Shelley in "The Cloud," and the "Ode to the West Wind." But Byron spoke in his own person. He was often so controlled by the emotions that seized him that, as in the "Fare Thee Well," the passionate but unadorned statement of immediate fact was sufficient to poetry. If this be a fault of relative mediocrity, others may decide; it was, at all events, a snare and a delusion for his imitators. Such work looks so simplea pen and paper and presto ! - a Byronic lyric, just as clear and as well rhymed (on comparison) as any of Byron's. Even the most callow imitator of Keat's " Ode on a Grecian Urn" cannot but see or feel that he has missed the color and delicacy of his model; but only a mature mind possesses the spiritual balance and insight to distinguish, in the issue, between what is simple, direct and vital and what is but jejune imitation, especially if the latter happens to be its own production. The real mastercraft in the nonchalant ease and colloquiality of Don Juan was in the same way, as observed by Legaré, all too little ap- 
preciated. Then, too, Byron is himself often slip-shod and crude, and many undoubtedly supposed, like any boyish imitator at his desk to-day, that, because they could succeed in copying Byron's defects, they had rivalled his merits.

Byron's relation to the then current homely sentimental verse of which "The Old Oaken Bucket" is typical, and to the equally current "prettily sentimental" with its conventional " Lines on Baby's Pink Slippers," "Stanzas to a Lady in the Casement, Plucking Honeysuckle," etc., it is hard to determine. Such verse corresponds directly to nothing in Byron, to little in Moore; yet the influence of both may be suspected, and, as Byron was the more dominant spirit, his influence may have been the more fundamental, and similar to that which he exercised, according to the critic, ${ }^{1}$ on the English lady L. E. L., namely, in heightening "the romantic tone and native sentimentality." It is the sentimentality of the era of Byron without its masculine vigor and largeness, trivialized by poverty of imagination and that self-conscious straining after unusual poetic themes which so often goes with it. Wordsworth undoubtedly influenced many in the choice of homely themes, and some of Woodworth's songs were once popularly attributed to Wordsworth ; ${ }^{2}$ Mrs. Hemans and L.E.L. influenced many in the choice of "pretty" ones. This phase of our verse is, however, a topic for special investigation.

Byron's position in America to-day was referred to in the opening paragraph. A reaction from extraordinary and somewhat meretricious fame has brought to the poet years of extraordinary and decidedly irrational neglect

${ }^{1}$ George Saintsbury in History of Nineteenth Century Literature.

2 " From the newspapers of England they were recopied in the United States as the productions of the great lake poet." Introduction to The Poems of Samuel Woodworth, 2 vols., N.Y., 1861, edited by his son. 
among those who speak his land's language. The Carolinian Age of the Restoration, with its ideals of good breeding and correct taste in literature, did not always understand the infinite variety and power of Shakespeare; the latter Victorian Age, in both England and America, with its ideals of sensuous beauty and artistic finish or spiritual suggestiveness in literature, has refused always to understand the infinite personality and power of Byron. If Byron was once a fad, anti-Byron is somewhat a fad to-day. To admire Byron to-day argues a coarse insensibility to the fine lines, to the delicate lights and shadows, to the overtones of poetry, or to the deep spiritual problems which fin (or enfin) de siecle poetry settles or illuminates. Byron is a barbarian who uses bad grammar and makes hobbling iambics; Byron has no philosophy; Byron is a poet for lawyers and bartenders. This is very like the cant that has been so summary with his morals and irreligion. Whether there be as many single lines of ultimate poetic charm in Byron as in Keats or Tennyson, or whether his philosophy of life ${ }^{1}$ be as profound and as satisfying as Wordsworth's or Browning's may be doubted; but Byron recorded - and recorded to the full - fifteen years of one of the most intense in passion and in thought of all human lives, a life lived in a tremendous epoch, near the world's noblest mountains and streams, in the midst of her fairest cities, a life echoing in its depths the $\chi^{\alpha \hat{\imath} \rho \epsilon} \phi \hat{\omega} s !$ of the Greek and the mehr Licht! of the German : let us keep the record.

1 This has been carefully examined. See Lord Byron's Weltanschauung, J. O. E. Donner, Helsingfors, 1897. 



\section{APPENDIX.}

The earlier American editions of Byron, in the libraries consulted, are given in the following list: ${ }^{1}$

1811, English Bards, ${ }^{2}$ Charleston, S.C. 1812, Childe Harold, i-ii, Phil. 1813, Giaour, Phil. I813, Giaour, Boston. 1814, Bride of Abydos, Boston. 1814, Bride of Abydos, Phil. 1814, Corsair, N.Y. 1814, Corsair, Phil. I8I4, Corsair, Boston. I8I4, Lara, Boston. I814, Lara, N.Y. I8I4, Ode to Napoleon, Boston. I8I4, Ode to Napoleon, N.Y. I814, Ode to Napoleon, Phil. I814, English Bards (with Ode to Napoleon), Boston. I8 $14{ }^{8}$ Works (2 vs.) ${ }^{4}$, Boston. I 815 , Hebrew Melodies, Boston. I815, Hebrew Melodies, N.Y. I815, Hebrew Melodies, Phil. I815, Curse of Minerva, ${ }^{5}$ Phil. 1816 , Siege of Corinth and Parisina, N.Y. I8I6, Ode on the Star of the Legion of Honor and Other Poems, N.Y. I816, Farewell to England with Other Poems (including Curse of Minerva), Phil. I8I6, Works (3 vs.), Phil. I8 1 7, Manfred, N.Y. I817, Childe Harold, iii, Boston. I817, Childe Harold, iii (with Prisoner of Chillon, Darkness, etc.), N.Y. I81 7, Works, N.Y. [1817, Pilgrimage to the Holy Land with the Tempest, a fragment, Phil.]. ${ }^{6}$ 1818, Childe Harold, iv, N.Y. I818, Childe Harold, iv, Phil. I819, Mazeppa (with Ode to Venice), Boston. 1820, Works (not complete to date), Phil. I82 I, Don

1 I must acknowledge indebtedness for the lists kindly sent me by Miss A. S. Mazÿck, assistant in the Charleston Library, by Mr. John Thompson, Mr. N. D. Hodges and Mr. H. L. Koopman, librarians respectively of Philadelphia, Cincinnati and Brown University, and by Mr. A. P. C. Griffin, Chief Bibliographer of the Library of Congress, Washington.

${ }^{2}$ First American from the third London edition.

${ }^{3}$ Note how remarkably Byron's London "year of revelry" and glory, 1814, affected American publishers.

4 "From the London edition," and not collected by American enterprise.

${ }^{5}$ De Silver \& Co., $8^{\circ}$. Before publication in England, whether with or without Byron's consent is not known. [?]

${ }^{6}$ Spurious, published by the well known house of M. Thomas. 
Juan, iii, iv, v, N.Y. I821, Marino Faliero, Phil. I821, Prophecy of Dante, Phil. I82 I, La Profezia di Dante, ${ }^{1}$ N.Y. I82 I, Works (4 vs.), N.Y. I822, Sardanapalus, Two Foscari, Cain, Boston. 1822 , Sardanapalus, Two Foscari, N.Y. 1822 , Cain, N.Y. 1823 , Island, N.Y. I 823, Vision of Judgment (with Southey's), N.Y. I823, Werner, Phil. I823, Don Juan, ix-xi, Albany. $\quad 1824$, Don Juan, xv-xvi, Phil. 1824 , Deformed Transformed, Phil. I 824 , Works (8 vs.), ${ }^{2}$ Phil. I 825 , Works (8 vs.), Phil. I825, Correspondence (earlier letters), Phil. I 825 , Don Juan, Baltimore. 1827 , Beauties of Byron, ${ }^{8}$ Phil. 1829, Works ("including suppressed poems"), ${ }_{4}^{4}$ Phil. 1830, Letters and Journals, edited by Thomas Moore, N.Y. I $83_{2}$, Works (8 vs.), Phil. I834, Mazeppa, ${ }^{5}$ N.Y. $\quad$ I 835 , Works (in verse and prose), ${ }^{6}$ N.Y. 1836 , Works (in verse and prose), N.Y. 1836 , Conversations with the Countess of Blessington, ${ }^{7}$ Phil. 1836 , Works, Phil. 1837 , Works (in verse and prose), N.Y. 1838 , Works, Phil. 1839 , Works, Phil. I843, Works (4 vs.), Phil. I844, Works, Phil. I844, Hebrew Melodies, N.Y. $\quad$ I846, Sardanapalus and Werner, ${ }^{8}$ N.Y. I 847 , Works, N.Y. I847, Childe Harold, Phil. I 848 , Childe Harold, Phil. r848, Werner, ${ }^{8}$ N.Y. 1849 , Tales and Poems ("with illustrated engravings on steel"), ${ }^{9}$ Phil. 1850 , Works (4 vs.), Cincinnati. ${ }^{10}$ I $8_{5} \mathrm{I}$, Works (in verse and prose), Hartford. r 85 I, Selected Works (Hours of Idleness, English Bards, Hebrew Melodies), Boston. $\quad$ I 85 I (?), Works, Boston. $\quad$ I $8{ }_{5}$ I, Correspondence with Lady Blessington, Cincinnati. 185 ?, Werner, ${ }^{11}$ N.Y.

1 Translated into terza rima by Lorenzo da Ponte, a well known teacher of Italian in New York.

2 With portrait, as usual in complete editions.

${ }^{3}$ It ran through at least ten editions.

${ }^{4}$ Lake's edition, several times reprinted.

${ }^{5}$ In The Republic of Letters, vol. $\mathrm{i}$.

${ }^{6}$ Halleck's edition, several times reprinted.

7 In Carey's Library of Choice Literature, vol. ii.

${ }^{8}$ In Modern Standard Drama Series.

9 One of the good bits of book-making by that once famous house, Carey \& Hart.

${ }^{10}$ Published by J. A. and U. P. James. The present head of this publishing house, Mr. D. L. James, has kindly furnished me with a memorandum: "If this was printed in Cincinnati it was from a set of stereotypes made in the East. My impression is that the sheets were printed in the East, probably in Philadelphia, with Cincinnati imprint, and then bound in Cincinnati."

11 In French's Standard Drama. 
185 ?, Sardanapalus (adapted by Charles Kean), N.Y. I8 $5^{2}$, Works (in verse and prose), Hartford. $\mathrm{r}_{53}$, Works ( 8 vs. in 4 ), Phil. I853, Works, N.Y. 1853 , Works (in verse and prose), Hartford. I856, Don Juan, Phil. I 85 ?, Works (1o vs.), Boston. 1864, Childe Harold, Boston. 1864, Works (ro vs.), Boston. 1865, English Bards, ${ }^{1}$ N.Y. I866, Works, Phil. I868, Works, Phil.

This list may be compared on the one hand with Gen. J. G. Wilson's privately printed list of American editions of Burns, on the other with the formidable lists of European editions of Byron in the last volume (1904) of Mr. E. Hartley Coleridge's Poems of Byron.

1150 copies, printed half in half, $8^{\circ}$ and $4^{\circ}$. 



\section{BIBLIOGRAPHY.}

(A) For Byron's influence, besides authors already noted, the following are important:-

ElzE's Biographie, chap. xi, 3 d ed., r886, Eng. trans., 1872.

KöPPEL's Biographie, Berlin, r903.

BLEIBTREU's Geschichte der englischen Litteratur.

TAINE's Histoire de la littérature Anglaise.

ROBERTSON's Hist. of Ger. Literature (use index), Blackwood, r9o2.

Gervinus' Geschichte des roten Jahrhunderts, Bd. viii.

HAzLITT's Spirit of the Age.

G. BRAndes, Hovedströmninger $i$ det I9 de Aarhundredes Litteratur, Copenhagen, 189o-4.

Dr. Отто Weddingen, Lord Byron's Einfluss auf die europäische Litteratur der Neuzeit.

Dr. Otтo Weddingen, Lord Byron und die russische Litteratur, in Archiv für das Studium der neueren Sprachen und Litteraturen, lxix, $2 x 4$.

- Byron i jego Wiek, Cracovie, 1896-7 (not translated, but of. report in Extrait du bulletin de l'Academie des Sciences de Cracovie).

Rudolph GotTschall, Byron und die Gegenwart, in Unsere Zeit, I866, p. 48 I ff.

A. Mickiewitz, Goethe und Byron in his Melanges, v. i, 1872 .

E. P. A. Hohenhausen, Rosseau, Goethe und Byron, Cassel, 1847 .

V. E. P. Charles, Vie et influence de Byron sur son époche, in his Études sur l'Angleterre au xix $x^{e_{1}}$ siècle, $\mathrm{r} 8_{5}$.

Henri Blaze de Bury, Tableaux romantiques de littérature et d'art, essay, Lord Byron et le Byronisme, Paris, 1878 .

W. J. Clark, Byron und die romantische Poesie in Frankreich, ${ }^{1}$ Leipzig, rgor.

${ }^{1}$ I must acknowledge especial indebtedness to this very able dissertation. 
VICtor Hugo, Sur lord Byron à propos de sa mort (a contemporary magazine article republished in his prose works).

H. Kraeger, Lord Byrone Beziehungen zu Amerika, in Wissenschaftliche Beilage zur Allgemeine Zeitung, r897, nos. 58-62. Washington Irving, "Newstead Abbey," in Crayon Miscellany.

(B) For further contemporary criticism on American literature, throwing light on our crude conditions or our desire for literary independence, see, especially :-

C. B. Brown, Preface to Edgar Huntley, I80 I.

Fisher Ames, "Essay on American Literature," pub. after his death, in I809.

W. E. Channing, "Remarks on a National Literature" (apropos of a "Discourse concerning the Influence of America on the Mind," delivered, Oct. $18,188_{2}$, " at the University in Philadelphia," by C. J. Ingersoll); reprinted in his works.

EDward Everett, "Progress of Literature in America," 1824.

John Neal, "American Writers" (in Blackzeood's), 1824 .

Knapp, Lectures on American Literature, 1829.

J. G. Whittier, Preface to Legends of Nere England, I831 ; (also his early reviews, as that of Evangeline, I847).

J. G. Verplanck, American History, Art, and Literature, 1833 ; (also his "American Scholar," 1836).

T. Flint, "Literature in the United States" (in London Athenaum), 1835 .

R. W. Emerson, "The American Scholar," I837.

[?] Commencement Oration on "American Literature," Cambridge, 1839 .

W. G. Simms, Viezers and Revieres, 1845 .

H. T. Tuckerman, Thoughts on the Poets, 1846 .

E. P. Whipple, Essays and Retiews, 1848 .

E. A. PoE, Collected Reviews and Essays (his lecture, "The Poets and the Poetry of America," was delivered first in 1843).

T. J. Buckingham, Personal Memoirs, 1853 . 
Walt Whitman, Preface to Leaves of Grass, first edition, 1855 .

H. B. Wallace, Literary Criticisms, 1856 .

V. E. P. Charles, Etudes sur la littérature et les mours des AngloAmericains, $d u$ xix siecle, I851; (note also the prejudiced accounts of travels by Englishmen, and the work on the American People, by the German, F. von Raumer).

Besides the above, much may be gleaned from the prefaces and biographical notices of the Anthologists, from the book reviews in magazines, and from magazine articles on American literature, for which latter see Poole's Index. Much bibliographical information may be found in Prof. B. Wendell's Literary History of America, and in Prof. W. P. Trent's History of American Literature. See also, American Authors (a bibliography), 1795-1895, by P. K. Foley, Boston (printed for subscribers, 1897); Check Lists of Bibliographies, Catalogues, Reference Lists of Authorities of American Books and Subjects, P. L. Ford, Brooklyn, I889; and the well known Dictionary of American Authors, by Oscar Fay Adams.

(C) The following Anthologies are the most important for American minor verse, and some of it is very minor:-

Beauties of Poetry, British and American (nineteen native writers represented), MatThew CaRey [Phil.], I79I.

American Poems, Richard Alsop. (This was the first, and the last of a proposed series). Litchfield, Conn., I793.

Columbian Muse, N.Y., I794.

Specimens of the American Poets ("with critical notices"), London, 1822 .

Columbian Lyre, Glasgow, 1828 .

Specimens of American Poetry, S. Kettel, Boston, I829.

American Commonplace Book of Poetry, G. B. Cheever, Boston, $183 \mathrm{I}$. 
The Rosary (more than half the selections are from American writers), T. J. Buckingham, Boston, I834.

The Poets of America, KeEse [Boston ?], 1839 .

Selections from the American Poets, W. C. Bryant, N.Y., I840.

Poets and Poetry in America, R. W. Griswold, 1842. (The Female Poets made their debut under Mr. Griswold's chaperonage in I 849.)

Cyclopedia of American Literature, E. A. and G. L. Durckinck, N.Y., 1855 .

A Library of American Literature, Stedman and Hutchinson, 1887 (vol. xi, r89o). 
.27 


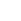




\section{VIT A .}

THE author was born in Plainfield, N.J., January $25,1876$.

$\mathrm{He}$ was a pupil in the public schools of that city till at the age of sixteen he removed with his parents to Bolton, Mass., where he completed his preparation for college alone. He entered Boston University, attending chiefly classes in English, Latin and Philosophy, under Professors Butler, Lindsay and Bowne, and graduated (A.B.) in 1898 . He was then a student of the same subjects at Harvard University under Professors Kittredge, Baker, Morgan, Marsh and James, and received the A.M. degree in 1899 . During a portion of the same year he was instructor in Latin in Boston University. In the fall of 1900 he went, as Fellow of Boston University, to Göttingen, Germany, where he heard Professors Morsbach, Heine, Roethe and Meyer, in English, Germanics and Comparative Philology. In r9or-2 he attended, at Bonn, lectures on English, Germanics and Philosophy, under Professors Trautmann, Bülbring, Wilmanns, Litzmann and Erdmann. In 1902-3, as Fellow in English of Columbia University, he attended lectures by Professors Price, Trent and William H. Carpenter. The author is glad of this opportunity to express to his teachers his sincere and lasting gratitude. 



\section{ERRATA.}

PAGR.

2 For Crecentius

"Cela

“. sentimentidi

" Frederich

" Heinrich

" Digde

" rapelle

"Werner

" Decembre

10 (and passim) For bourgeoise

11 For Benjamin Thompson

11 " Blackstone

24 "Sir Charles Moore

32 " much and

38 " Atheneum

" Fables

" Cossens

" England and Switzerland

" Greenville

" rather, facile

" Juvenalia

" closely

Dele " the spot on."

For Grisnold

71 (and passim) For Matthews

75 Insert "many" after "been said."

76 Substitute a period for the comma after "are his."

77 For Advertizer

"Stanzas to Cadiz

“Mrs. S. A. Lewis

For Peacock

" imitations

" thou has

" drugge

" mastadons

" as Byron

" aimed at

" Melanges

123 and 125 For Charles

123 For époch

124 "Byrone

124 “. J. G. Verplanck read Crescentius.

"Cela.

" sentimentidi.

.. Frederik.

" Henrik.

" Digte.

"rappelle.

"Wiener.

" Décembre.

" bourgeois.

" Benjamin Thomson.

. Blackmore.

" Sir John Moore.

" much.

. A thenæum.

" Fable.

" Cozzens.

" Subjugation of Switzerland.

" Grenville.

" rather facile.

"Juvenilia.

" close.

read Griswold.

" Mathews.

read Advertiser.

" The Girl of Cadiz.

"Mrs. E. Anne Lewis.

read Robert Pollock.

" imitation.

" thou hast.

" drudge.

" mastodons.

" than Byron.

" sought.

"Mélanges.

"Chasles.

" époque.

"Byrons.

" G. C. Verplanck. 



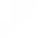

. 


\section{$\bullet$}

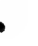



PR

4388

44

1905

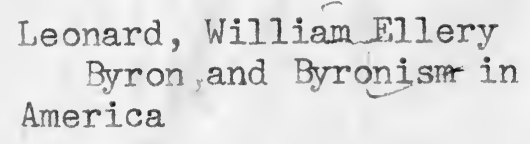

PLEASE DO NOT REMOVE

CARDS OR SLIPS FROM THIS POCKET

UNIVERSITY OF TORONTO LIBRARY 
ing

26

19.

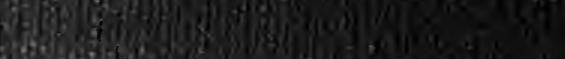

thas

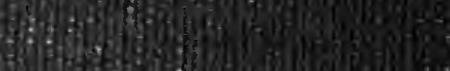

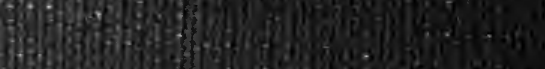

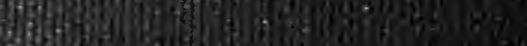

is

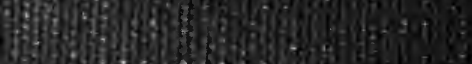

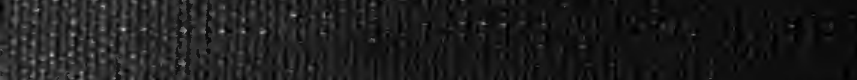

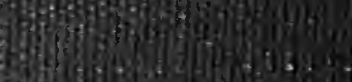

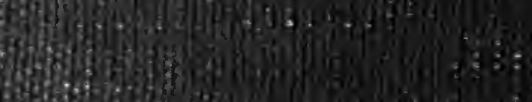

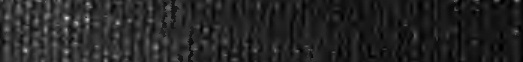

3.

6. 